\title{
I-10025-0220
}

BJC/OR-2885

\section{Baseline Environmental Analysis Report for the K-1251 Barge Facility at the East Tennessee Technology Park, Oak Ridge, Tennessee}
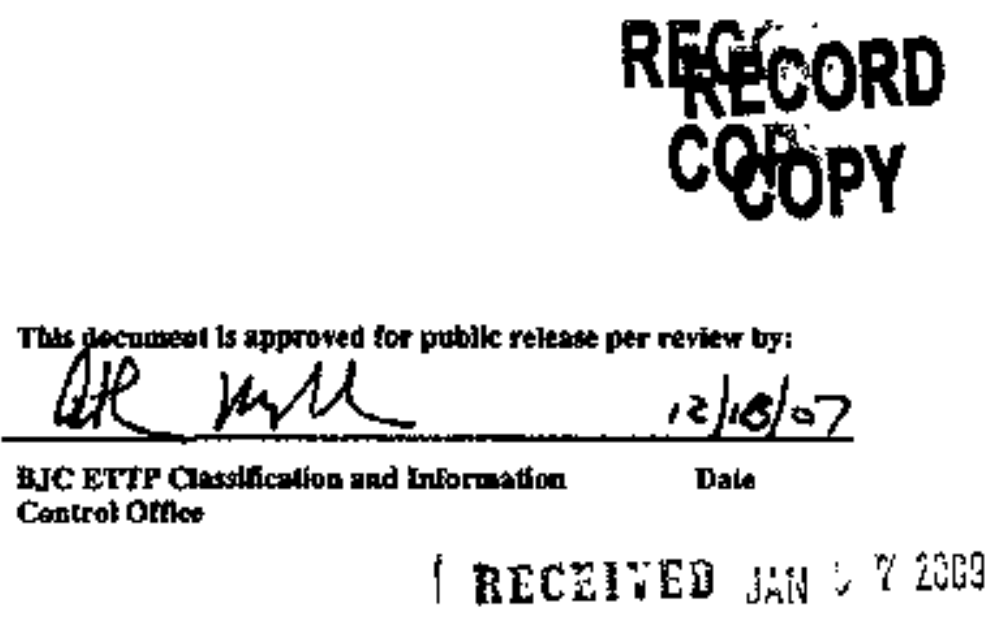


\section{SCIENCE APPLICATIONS INTERNATIONAL CORPORATION}

contributed to the preparation of this document and should not be considered an eligible contractor for its review. 


\title{
Baseline Environmental Analysis Report for the K-1251 Barge Facility at the East Tennessee Technology Park, Oak Ridge, Tennessee
}

Date Issued-December 2007

\author{
Prepared by \\ Science Applications lntemational Corporation \\ Oak Ridge, Tennessee \\ under subcontract 23900-BA-PR007U \\ under work release, 00800
}

Prepared for the

U. S. Department of Energy

Oftice of Nuclear Fuel Supply

\section{BECHTEL JACOBS COMPANY LLC} managing the

Environmental Management Activities at the East Tenuressee Technology Park

Y-12 National Security Complex Oak Ridge National Laboratory under contract DE-AC05-980R22700

for the

U. S. DEPARTMENT OF ENERGY 
This report has been prepared by Science Applications International Corporation (SAIC) for the sole and exchusive tse of Bechtel Jacobs Company LLC (BJC) and the U.S. Department of Energy. Any other person or entity obtaining, tsing, or relying on this report hereby acknowledges that they do so at their own risk, and thot SAIC shall have no responsibility or liability for the consequences thereof. This report is prepared by $\$ A I C$ in accordance with the Comprehensive Environmental Response, Compensation, and Liability $A$ ct of 1980 (CERCLA) $120(\mathrm{~h})(\mathrm{l})$ and $(3)(\mathrm{c})$ requirements.

This report is intended to be used in its entirety. Excerpts, which are taken out-of-context, num the risk of being misinterpreted and are, therefore, not representative of the findings of this assessment. Opinions and recommendations presented in this report apply only to site conditions and features as they existed at the time of SAIC's site visit, and those inferred from information observed or available at that time, and cannot be applied to conditions and features of which SAIC is unavare and has not had the opportunity to evaluate.

The results of this report are based on record reviews, site reconnaissance, interviews, and the radiological report reviewed and approved by BJC. SAIC has not made, nor has it been asked to make, any independent investigation concerning the accuracy, reliability, or completeness of such information.

All sources of information on which $\$ A I C$ has relied in making its conclusions are identified in Chap. 7 of this report. Any information, regardtess of its source, not listed in Chap. 7 has not been evaluated or relied upon by SAIC in the context of this report. 


\section{CONTENTS}

FIGURES vii

TABLES vii

ABBREVIATIONS . ix

EXECUTIVE SUMMARY ..$x i$

1. PROPERTY IDENTIFICATION ...................................................................................

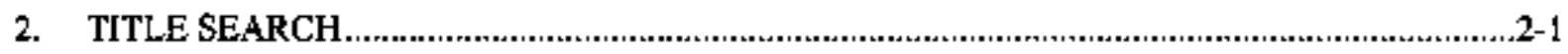

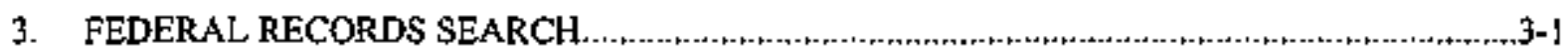

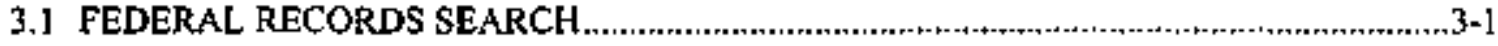

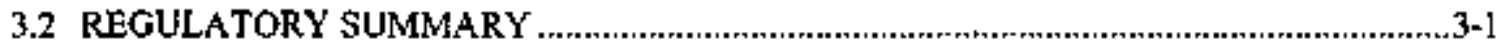

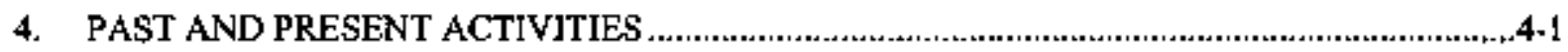

4.] PAST AND PRESENT ACTIVITIES FOR THE REAL PROPERTY PROPOSED

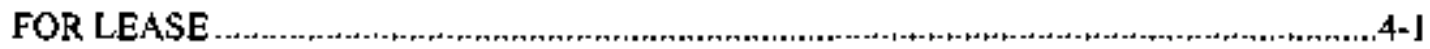

4.2 PAST AND PRESENT ACTIVITIES FOR THE ADJACENT PROPERTY

5. RESULTS OF VISUAL AND PHYSICAL INSPECTIONS .................................................. 5.] VISUAL AND PHYSICAL INSPECTIONS OF THE PROPERTY FOR LEASE ..................

5.2 VISUAL AND PHYSICAL INSPECTION OF ADJACENT PROPERTY .............................. I

6. SAMPLING AND SURVEY RESULTS

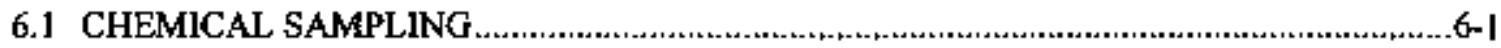

6.1 .1 Kistorical Soll Samples …...................................................................................... 6

6.1 .22007 Soil Sampling ..............................................................................................6-1

6.1.3 Concrete Pad Sample Results ..................................................................................6-7

6.2 RADIOLOGICAL SURVEYS AND SAMPLING.......................................................6-8

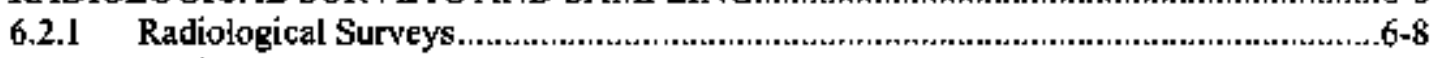

6.2.2 Radiological Sampling ........................................................................

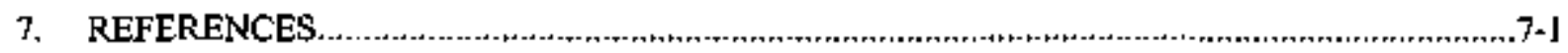

APPENDIX A STUDY AREA MAPS FROM RECORDS SEARCH

APPENDLX B SAMPLING AND ANALYSIS PLAN FOR THE K-1251 BARGE FACLLITY.......... B-J

APPENDIX C RADIOLOGICAL SURVEY PLAN FOR THE K-]25 1 BARGE FACILITY ...............-1

APPENDIX D WALKOVER INSPECTION PROTOCOL

APPENDIX E RJSK EVALUATION FOR THE K-125I BARGE FACILITY …................................ E-1 


\section{FIGURES}

1.1 Location of the K-1251 Barge Facility witbin ETTP..................................................................1-2

1.2 Lease footprint for the K-1251 Barge Facility, .......................................................................

1.3 Aerial photograph of the K-1251 Barge Facility (circa 1998)...................................................

1.4 Aerial photograph of the K-125 I Barge Facility during TDOT constnuction work on the highway bridge (March 2000) ...................................................................................

6.1 K-1251 Barge Facility sampling locations, ...............................................................................,6-2

\section{TABLES}

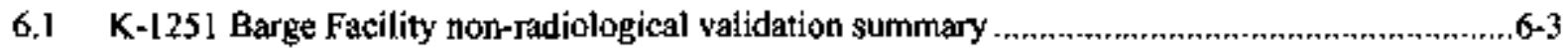

6.2 K-125] Barge Facility chemical analytical results sutunary ...................................................6-4

6.3 K-1251 Barge Facility study area polychlorinated bjphenyls results ....................................6-5

6.4 K-l251 Barge Facility volatile organic compounds results ..............................................6-5

6.5 K-1251 Barge Facility semivolatile organic compounds results ......................................6-6

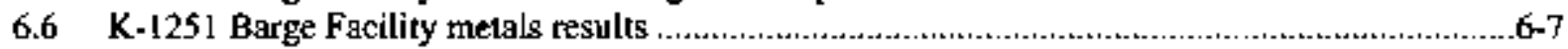

6.7 Analytical results for concrete samples collected at the K-1251 Barge Facility ...........................6-8

6.8 Summary of contamination and dose rates ...........................................................................

6.9 Fixed-timed measurements.............................................................................................. $6-11$

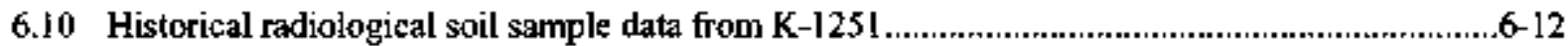

6.11 Summary of K-1251 surface and subsurface soil samples for radiological analyses ..................6-13

6.122007 Radiological soil sample data from the K-1251 Barge Facility ........................................6-14

$6.13 \mathrm{~K}-1251$ summary statistics for tadionuclides with tistorical data..............................................6-16 


\begin{tabular}{|c|c|}
\hline & ABBREVIATIONS \\
\hline bgs & below ground surface \\
\hline BJC & Bechtel Jacobs Company LLC \\
\hline $\begin{array}{l}\text { CERCLA } \\
\mathrm{cm}^{2}\end{array}$ & $\begin{array}{l}\text { Comprehensive Environmental Response, Compensation, and Liability Act of } 1980 \\
\text { square centimeters }\end{array}$ \\
\hline COE & $\begin{array}{l}\text { U.S. Amy Coms of Engineers } \\
\text { counts per minute }\end{array}$ \\
\hline CROET & Community Reuse Organization of East Tennessee \\
\hline DCGL & derived concentration guideline level \\
\hline DOE & U. S. Department of Energy \\
\hline dpm & disintegrations per minute \\
\hline ELCR & excess lifetime cancer risk \\
\hline EPA & U. S. Environunental PJotection Agency \\
\hline ESU & exterior survey unit \\
\hline ETTP & East Tennessee Technology Park \\
\hline H] & hazard index \\
\hline HQ & hazard quotient \\
\hline LSU & land survey unit \\
\hline $\mathrm{NaI}$ & sodiun iodide \\
\hline OREIS & Oak Ridge Environmental lnformation System \\
\hline ORGDP & Oak Ridge Gaseous Diffusion Plant \\
\hline ORO & Oak Ridge Office \\
\hline ORR & Oak Ridge Reservation \\
\hline $\mathrm{PCB}$ & polychlorinated biphernyl \\
\hline PRG & preliminary remediation goal \\
\hline RADCON & Ratiological Control (Organization) \\
\hline RCRA & Resource Conservation and Recovery Act of 1976 \\
\hline RL & remediation level \\
\hline ROD & Record of Deciston \\
\hline SAP & Sampting and Analysis Plan \\
\hline SVOC & semivolatite organic compound \\
\hline TVA & Tennessee Valley Authority \\
\hline $\mathrm{UF}_{6}$ & uranium hexafluoride \\
\hline Voc & volatile organic conpound \\
\hline
\end{tabular}




\section{EXECUTTVE SUMMARY}

This report documents the baseline environmental conditions of the U. S. Department of Energy's (DOE's) K-1251 Barge Factity, which is located at the East Tennessee Technology Park (ETTP). DOE is proposing to lease the facility to the Community Reuse Organization of East Tentessee (CROET). This report provides supporting information for the use, by a polential lessee, of government-owned facilitics at ETTP. This report is based upon the requirements of Sect $\mathbf{1 2 0}$ (h) of the Comprehensive Environmental Response, Compensation, and Liabilily Act of 1980 (CERCLA).

The lease footprint is slightly over 1 acre. The majority of the lease footprint is defined by a perimeter fence that surrounds a gravel-covered area with a small concrete pad within it. Also included is a gravel drive with locked gates at each end that extends on the east side to South First Avenue, providing access to the facility. The facility is located along the Clinch River and an inlet of the tiver that forms its southem boundary. To the east, west, and north, the lease footprint is surrounded by DOE property.

Preparation of this report included the review of goverument records, tille documents, historic acrial photos, visual and physical inspections of the property and adjacent properties, and interviews with current and former employees involved in the operations on the real property to identify any areas on the property where hazardous substances and petroleum products or their derivatives and acutely hazardous wastes were known to have been released or disposed. Radiological surveys were conducted and chemical samples were collected to assess the facility's condition. The following is a sunnary of the findings of the evaluation that was perfonned:

- The primary historical use of the K-125] Barge Facility was tor the storage and transfer of uranium hexafluoride ( $\mathrm{UF}_{6}$ ) cylinders for or from barge transport. The facility began operating in 1953. It was removed from operation in the early 1990s, and all equipment (e.g., a crane) was removed in 1995. The facility is curently inactive.

- Although it is known that $\mathrm{UF}_{6}$ cylinders wete stored and transferred at the facility, information regarding duration of storage and specific quantities of the chenticals that were stored or transferred is not available. Although the chemical compound $U_{6}$ is not listed as a bazardous substance in 40 Code of Federal Regulations (CFR) 302.4, the component radionuclides of this chemical compound are included and are subject to reportable quantity (RQ) reporting. Historical information does not indicate that any releases occurred.

- Radiological surveys of the lease footprint have been conducted. The data were analyzed to determine whether any residual contamination was present and might exceed the derived concentralion guideline level established for each of the survey units. Survey results show that the K-1251 Barge Facility bad no areas of elevaled residual radioactivity present above DOE surface contamination limits [t.e., 1,000 disintegrations per minute (dpm) $/ 100 \mathrm{~cm}^{2}$ for resnovable alpha and beta-garnra and $5000 \mathrm{dpm} / \mathrm{L} 00 \mathrm{~cm}^{2}$ for total alpha and beta-gamma].

- K-1251 is not located within ETTP Zones 1 or 2, which were eslablished to address the potentially impacted areas of ETTP (DOE 2002); thus, no cleanup levels have been established for areas outside of Zones 1 or 2, which includes the area occupied by K-1251. However, for comparison pupposes, Zone I remediation levels (RLs) haye been used for screening analytical results for soils and concrete at $\mathrm{K}-1251$.

- In 2007, surface and subsurface soil samples were collected from three locations, and two samples were collected from the surface of the concrete pad. The purpose of the sampling was to determine 
whether any contamination was present due to polential bislonical releases from the UF $_{6}$ cylinders or whether historical relesses of hydraulic fluids, lubricating oils, or fuels from operation and maintenance of a large crane used to move the cylinders occurred. Analysis was conducted tor volatile organic compounds (VOCs), semivolatile organic compounds (SVOCs), radionuclides, metals, and polychlorinated biphenyls (PCBs).

- Soil samples from the lease footprint and concrete core samples from the pad in the lease footprint identified VOCs, SVOCs, PCBs, metals, and radionuclides in the soil samples collected from the lease footprint, and PCBs were detected in the samples collected of the concrete pad. Radiological constituents ${ }^{137} \mathrm{Cs}_{3}{ }^{60} \mathrm{Co}_{r}{ }^{239} \mathrm{Pu},{ }^{226} \mathrm{Ra},{ }^{250} \mathrm{Th},{ }^{334} \mathrm{U},{ }^{235} \mathrm{U}$, and ${ }^{538} \mathrm{U}$ were detected above backeground levels in some samples.

- Preliminary remediation goals (PRGs) calculated at the IE-5 excess lifetime cancer risk (ELCR) or the 1,0 hazard quotient (HQ) tevels have been established for the site for screening purposes. Only $\mathrm{Cs}^{1 \mathrm{It}}$ exceeded the PRGs calculated at the 1E-5 ELCR levet.

- Evaluation of soil and concrete samples from the lease footprint indicates no exceedances of the Zorte 1 RLs.

- The U. S. Environnental Protection Agency bas establisted a generally acceptable target risk range of E-04 to E-06 (also expressed as $10^{-4}$ to $10^{6}$ ) and a generally acceptable bazard index (Hl) of 1 . The screening-level risk estimate for the stuxly area soils in the K-125I Barge Facility footprint indicated that the cumulative risks did not exceed the generally acceptable target risk range of E-04 to E-06 (also expressed as $10^{-4}$ to $10^{6}$ ) or an $\mathrm{HI}$ above 1 ; therefore, a full risk calculation was not conducted. The risk scretening was consitered indicative of the low liketihood of adverse health effects associated with worker exposure.

- Because the radiological survey and all sampling results were below established himits such as RLs, and because the risk screen indicated a low likelibood of adverse health effects associated with exposure to the lease space, the subject facility is suitable for lease. 


\section{PROPERTY IDENTIFICATION}

The area discussed in this baseline envionenental analysis report is located in the southem portion of the East Tennessee Technology Park (ETTP) [formerly the Oak Ridge Gaseous Diffusion Plant (ORGDP) or K-25 Site] on the Oak Ridge Reservation (ORR) in Roane County, Tennessee. It includes the K-1251 Barge Facility, including its access road. Figure l.1 shows the location of the proposed lease footprint, and Fig. 1.2 designates the boundary of the footprint. Figures 1.3 and 1.4 are aerial photographs of the K-1251 Barge Facility site circa 1998 and 2000 , respectively.

The lease footprint is slightly over 1 acre. The majority of the lease footprint is defuned by a perimeter fence that surrounds a gravel-covered area with a small concrete pad within it. Also included is a gravel drive with locked gates at each end that exiends on the east side of the facility to South First Avenue, providing access to the facility. The facility is located along the Clinch River and an inlet of the river that forms its southem boundary.

Past and present operations at the former K-1251 Barge Facility are described in more delail in Chap. 4 of this report.

Preparation of this report included a detailed search of government records, title documents, and historic aerial photos; visual and physical inspections of the property and adjacent properties; and interviews with current and former employees involved in the operations on the real property to identify any areas on the property where hazardous substances and petroleum products or their derivatives were known to tave been released or disposed. 


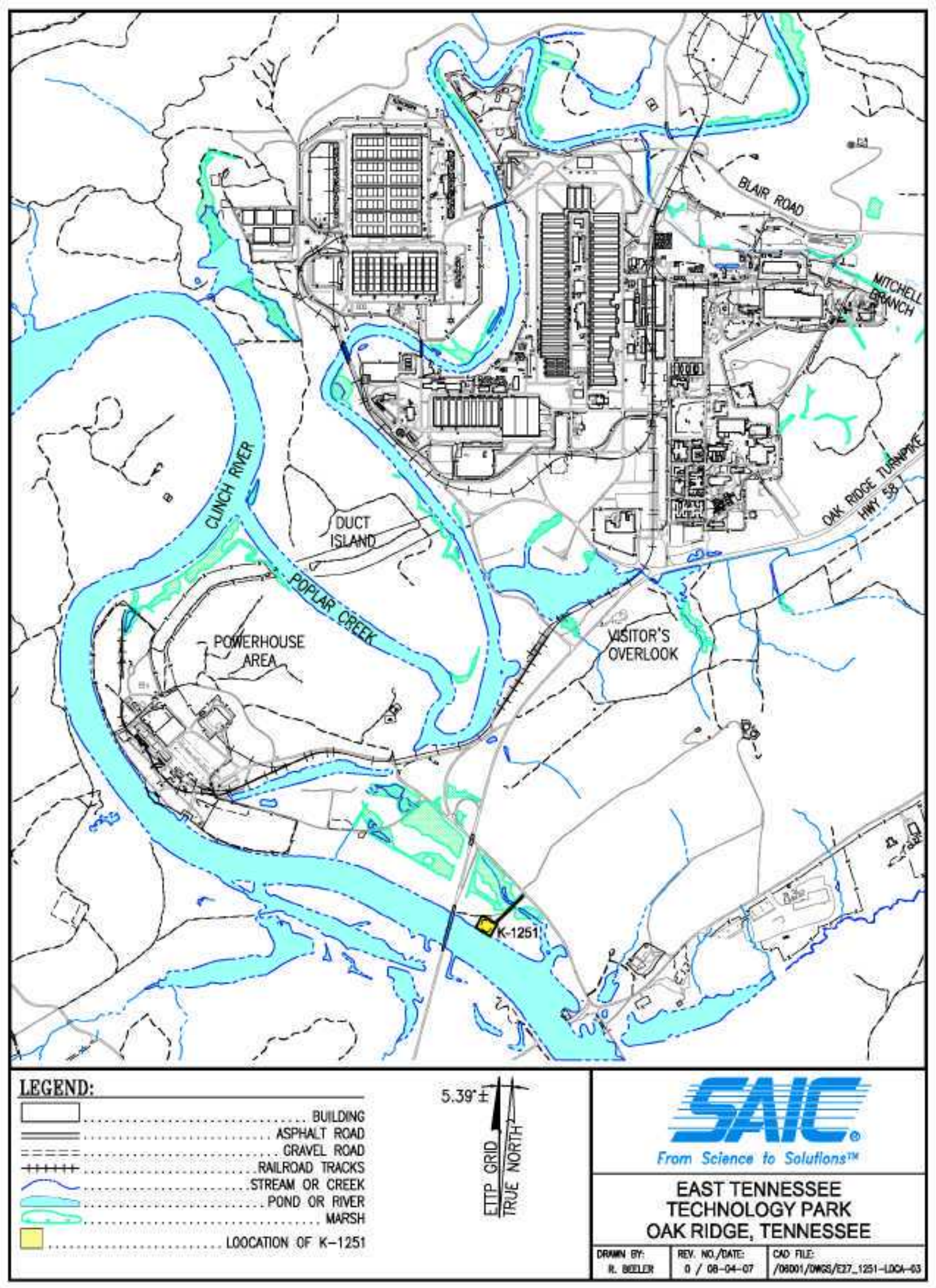

Fig. 1.1. Location of the K-1251 Barge Facility within ETTP. 


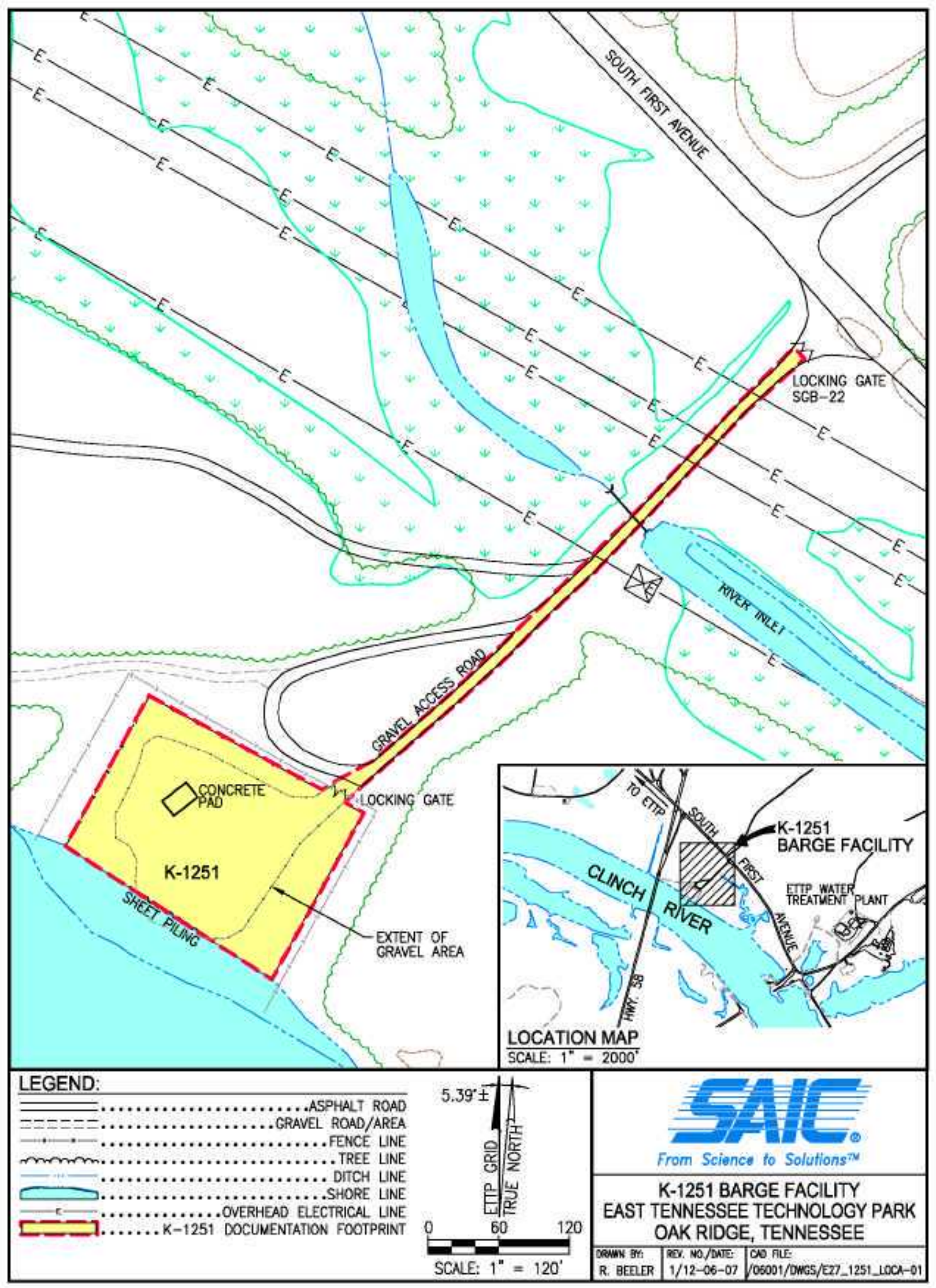

Fig. 1.2. Lease footprint for the K-1251 Barge Facility. 


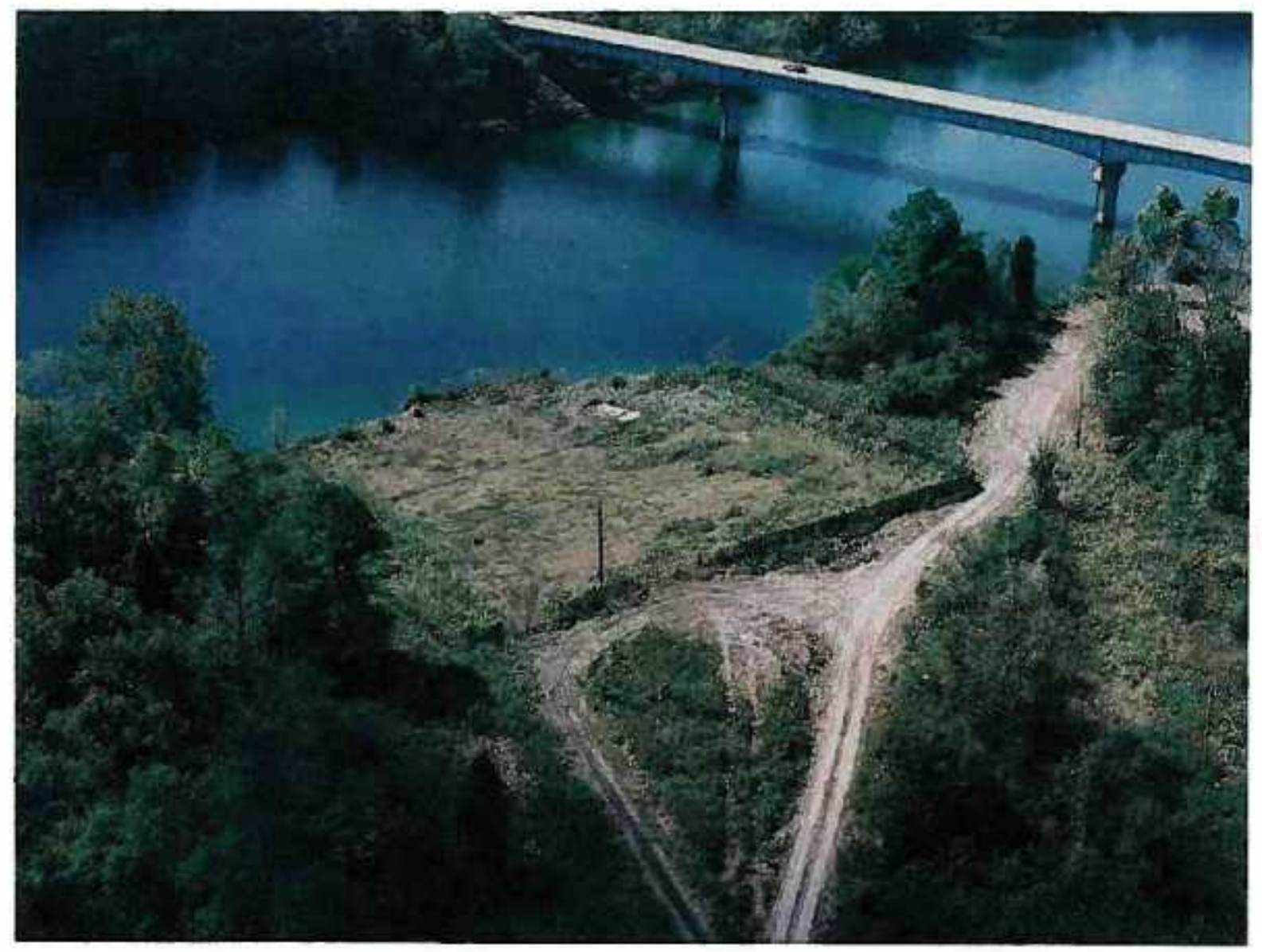

Fig. 1.3. Aerial photograph of the K-1251 Barge Facility (circa 1998). 


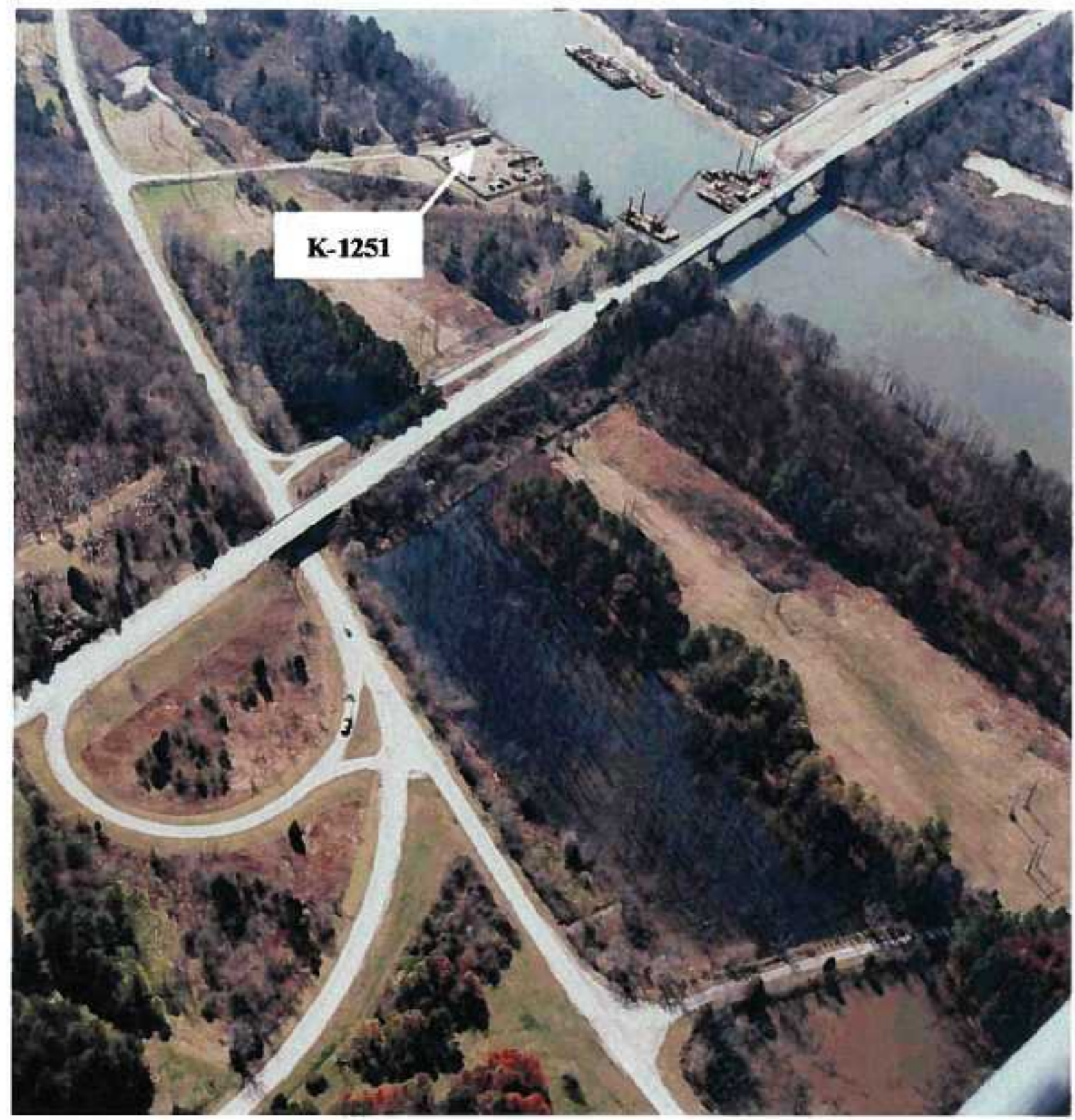

Fig. 1.4. Aerial photograph of the K-1251 Barge Facility during TDOT construction work on the highway bridge (March 2000). 


\section{TITLE SEARCH}

On August 29, 2007, a visit was made to the state of Tennessee Roane County Register of Deeds office to conduct a review of the recorded deeds documenting previous ownership of the land tract $\mathrm{H}-738$ where the K-1251 Barge Facility is located. The deeds contained no information or references to olher recorded evidence that, prior to U. S. Department of Energy (DOE) ownership, the property was utilized for the storage of hazardous substances and/or petroleur products or their derivatives. Additionally, no information contained in the deeds would indicate that hazardous substances and/or petroleum products or their derivatives were released from or disposed of on the property. Prior to acquisition by the government, the area was farmland and was a combination of cultivated fields, pastures, and forested areas.

The deeds that conveyed the property from the previous owner to the U.S. Government, and deeds that conveyed the property to that previous owner, were reviewed as a part of the title search. Generally, the deeds from the previous two owners of a particular ORR parcel provide information that goes back to the early 1900 s or even eartier. The deeds were teviewed for any references to previous land uses (e.g., homeslead, farm, school, business, etc.). Also reviewed were any easements or conveyances referenced in the deeds that might indicate that portions of the land were used for pipelines, power lines, etc. Partial disposal or acquisition conveyance deeds were also reviewed because, in some instances, the land conprising a large farm had been acquired via several separate acquísitions.

In addition, property assessment records from the County Property Assessor's Office were reviewed because these documents may also contain evidence of a particular land use. Survey or subdjwision maps referenced in deeds and maintained in the Register of Deeds office were also reviewer for any indications of a previous land use. Furthemore, because the Tennessee Valley Authority (TVA) was the previous owner of several large tracts of ORR land, land acquisition maps prepared by the TVA were also reviewed for prior land use. The U. S. Army Corp of Engineers (COE) was another source of information that was contacted.'

\footnotetext{
'Energy Systems 1996, Real Estate Section of Comprehensive Environmental Response, Compensation, and Liablity Act (CERCLA) Sect. I2O(h) Revlew, authored by W. W. Ter, Jr., Real Estate Manager, Lockheed Marlin Energy Systems, Jic., Oak, Ridge, TN, August 9, 1996.
} 


\section{FEDERAL RECORDS SEARCH}

\subsection{FEDERAL RECORDS SEARCH}

In 1997, the TVA in Knoxvilie, Tennessee (TVA 1997), and the COE District Office in Nasbville, Tennesset (COE 1997), were contacled to determine if they maintained any records reflecting past or present land use relative to the land that is now ETTP. Neither TVA nor COE had any infomation regarding the history of past or present land use that would indicate if hazardous substances or petroleum products or their derivalives were stored or released on the site.

Acrial photographs readily avaitable from federal, state, and local govermuent agencies may reflect prior use of the real property. Copies of these photographs and maps are maintained on file in the U. S. Department of Energy-Oak Ridge Office (DOE-ORO) Real Estate Office.

\section{Aerial Photographs:}

\section{Photograph Nos. and Date}

No, 130-3-9, dated 1939

Nos. 820-2-20 through -23 and 820-3-20 through -24, dated September 25, 1942

\section{Flight By \\ Unknown}

Aero Service Corp. for \$tone and Webster
Source

DOE-ORO, Real Estate Office

DOE-ORO, ReaI Estate

Office

These photographs, which were taken in 1939 and 1942, show that the land where the study area is located was predominantly used for agricultural purposes. Approximately $90 \%$ of the property was used in some type of agricultural pursuit, and the remaining property was wooded. A map depicting pre-World War II structures, archeological sites, and cemeteries that were present in the area of ETTP is included, in Appendix A.

A topographic map of the area, identified as Sect. A-l of the ORR, was prepared on November 2, 1942, by Aero Services Corporation for Stone and Webster.

A real estate map (sheet 9 of 16) prepared by the U. S. Army on February 19, 1945, shows that Land Tract No. H-738 is the Fand tract upon which the K-1251 Barge Facility is eurrently located. This 1945 map and a May 1, 1958, real estate map (sheet 2 of 3) also depict the various land tracts that were purchased by the U. S. Government and upon which the water distribution system is located.

Neither the aforementioned photographs nor maps contained any information regarding the history of the past fand use that would indicate that storage or releases of hazardous substances or petroleum products or their derivatives have occurred on the land where Land Tract H-738 is localed. Copies of the 1942 topographic map and real estate map are maintained in the DOE-ORO Real Estate Office.

\subsection{REGULATORY SUMMARY}

As discussed previously, priar to ownership by DOE (and its U.S. Govenment predecessor agencies), the property was a combination of famland and forest. Any DOE operations within the footprint of the K-1251 Barge Facility area occured under DOE's own authority prior to 1984 [DOE became subject to external regulations, including the Resource Conservation and Recovery Act of 1976 (RCRA), in 1984]. Based on interviews with employees and a review of records, there was no 
evidence found of releases of hazardous substances or petroleum products or their derivatives that would preclude its identification as an uncontaminaled parcel.

Records (containing information about spills, permits, or permit violations) and interviews with employees or former employees ${ }^{2,3}$ do not indicate that any regulatory actions have occurred wilhis the footprint of the K-125] Barge Facility. Therefore, no regulatory responses have been invoked,

\footnotetext{
¿ BJC 2004a. Personal communications with T. G. Ramsey (fomerly employed al the East Temmessee Technology Patk) in May.

${ }^{3}$ OMI 2004. Personal communications with 5. E. Russell of Operations Management intemational in May. 


\section{PAST AND PRESENT ACTIVITIES}

\subsection{PAST AND PRESENT ACTIVITIES FOR THE REAL PROPERTY PROPOSED FOR LEASE}

The forme K-125l Barge Facility is located across the Oak Ridge Turnpike from ETTP, along the Clinch River. [The facility has also been called K-1251 Barge Loading Dock and the K-I251 Barge Unloading Facilities (Stanley 1999; LMES 1997).] The K-1251 Barge Facility was constructed in 1952 and began operations in 1953. Included as part of the facilities were a 383- $\mathrm{ft}^{2}$ metal frame and metal pankl building and a large crane. The facility was removed from operation in the carly 1990s. The equipment was removed and the 383- $\mathrm{ft}^{2}$ metal building was dismantled in 1995. The facility is currently inactive. The K-125I Barge Facility was used to transfer uranium hexaflworide $\left(\mathrm{UF}_{6}\right)$ cylinders. Barges carrying loads of $\mathrm{UF}_{6}$ cylinders on the Clinch River were unloaded, and the cylinders were stored in an area adjacent to the riverbank. Information about the duration of storage or quantities of $\mathrm{UF}_{6}$ stored was not available. $\mathrm{UF}_{6}$ cylinders were transferred (i.e., moved from barges to the storage arta and subsequently moved from the storage area to trucks) at the facility

\subsection{PAST AND PRESENT ACTIVITIES FOR THE ADJACENT PROPERTY}

The nearest mon-DOE property to K-125] is Highway 58/Oak Ridge Tumpike, which is located about $450 \mathrm{ft}$ north of K-1251. At its closest point, the road is elevated above K-1251 as the tumpike crosses the Clinch River (see Figs. 1.3 and 1.4). There is no indication that activities from this non-DOE area would have contributed any contamination to the area to be leased. There are no facilities or other fearures in close proximity to the K-1251 Barge Facility. 


\section{RESULTS OF VISUAL AND PHYSICAL INSPECTIONS}

\subsection{VISUAL AND PHYSICAL INSPECTIONS OF THE PROPERTY FOR LEASE}

\section{K-1251 Barge Facility}

The major portion of the footprint (except for the access road) is enclosed by a chain-link fence. The fenced area is mostly covered by grass except for the remains of the concrete pad located in the northem portion of the footprint. The concrete pad is broken and has small trees and shrubs growing through the cracks. The footprint is mostly level but contains some lower lying areas that could hold standing waler after a rain event. The southwestern edge of the footprint borders the river and contains a barge-docking shelf.

During the visual inspection of the lease space, no other equipment or materials were present within the proposed lease footprint. Small quantities of gravel and/or asphait rubble were observed; they are from the gravel road and laydown areas inside the fence. Scattered scrap metal pieces were also observed on the ground throughout the study area.

\subsection{VISUAL AND PHYSICAL INSPECTION OF ADJACENT PROPERTY}

The adjacent areas are owned by DOE and are undeveloped. No adjacent areas are knowa to have been used for any activities involving hazardous substances or petroleum products or their derivatives. 


\section{SAMPLING AND SURVEY RESULTS}

Based on discussions with the U.S. Environmental Protection Agency (EPA), it has been agreed that the necd to collect samples to support lease activities will be deternined on a case-by-casc basis. Factors sucb as a facility's past operational history and geographic location will be considered. In addition, the bistory and knowledge of activities at adjacent properties are evaluated.

Sections 6.1 and 6.2 present the results of the chemical and radiological soil sampling that was performed in the study area Radiological survey results are discussed in Sect. 6.2.

\subsection{CHEMICAL SAMPLJNG}

This section presents and discusses the results of the chemical soil sampling that was performed in the study area. In order to meet data requirements for the risk screening, additional samples were needed to supplement the existing data for the K-1251 study area (see Sect. 6.1.1). Three soil sampling locations indicated in Fig. 6.1 were selected on a judgmentat basis. In addition, two samples of the surface of the concrete pad were collected to determine the presence or absence of PCBs at the concrete pad. See Appendix B for the K-1251 soil Sampling and Analysis Plan (SAP).

This section discusses the results of the cumrent sampling and concludes with a summary of the results. K-125] is not located within ETTP Zones 1 or 2, which were established to address the potentially impacted area of ETTP (DOE 2002); thus, no cleanup levels have been established for areas outside of Zones 1 or 2, which includes the area occupied by K-1251. However, for comparison purposes, Zone 1 remediation levels (RLs) have been used for screening analytical resulis for soils and concrete at K-1251.

\subsubsection{Historical Soil Samples}

A search of the Oak Ridge Environmental Information System (OREIS) database showed data are available from only one historical soil semple within the K-1251 footprint. However, this sample (RAD436), collected in 1994, was quantified for radionuclides only. Thus, no bistorical chemical sarnple results are available for $\mathrm{K}-125 \mathrm{~s}$. The resutts for the historical radiological sample are discussed in Sect. 6.2.2.1.

\subsubsection{Sojl Samplinte}

In August 2007, eight surface and subsurface soil samples were collected from three locations (see Fig. 6.1) at the K-125l Barge Facility. Samples were collected in accordance with the approved K-1251 Barge Facility SAP. One sample was collected at each of the following depths at each of the three locations: 0.0 to $0.5 \mathrm{ft}$ below ground surface (bgs), 0.5 to $2.0 \mathrm{ft} \mathrm{bgs}$, and 2.0 to $10 \mathrm{ft} \mathrm{bgs}$, with the exception of location 02 where the 0.0 to $0.5 \mathrm{ft}$ bgs and 0.5 to $2.0 \mathrm{ft}$ bgs depths were sampled. Ail samples collected from the three soil sampling locations were quantified for VOCs, SVOCs, metals, PCBs, and radionuclides (results for radiological sampling are provided in Sect. 6.2). 


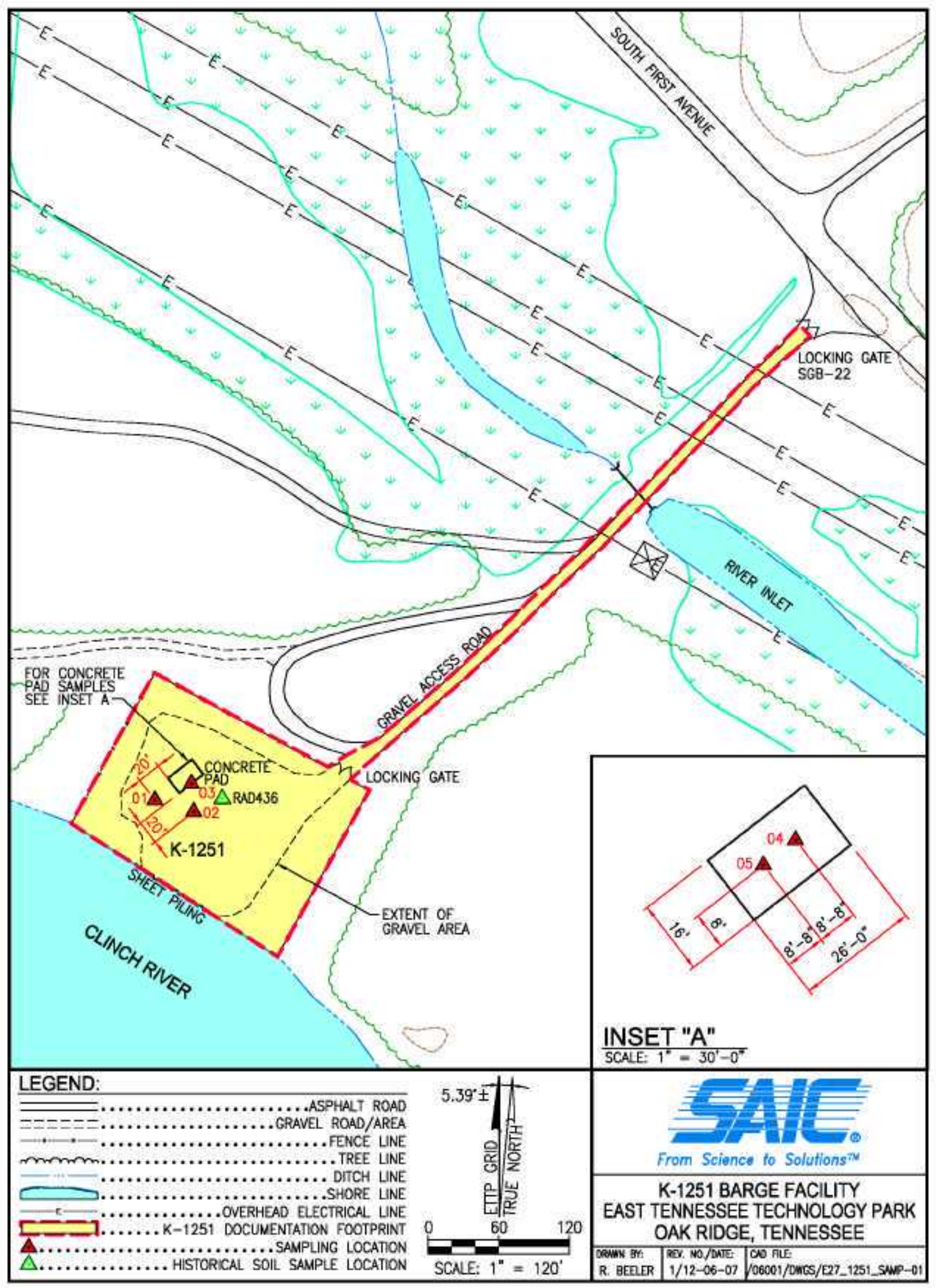

Figure 6.1. K-1251 Barge Facility sampling locations. 


\subsubsection{Soll sampling results}

\section{Data Validation}

During the data validation process, laboratery data were assigned appropriate data validation flags. These flags wete as described below:

"U" When the material was analyzed for but not detected above the level of the associated value.

" $\mathrm{j}$ When the associated value was an estimated quanlity (indicating there was cause to question the accuracy or precision of the reported data).

"UJ" When the analyte was analyzed for but not detected above the associated value; however, the reported value was an estimate and demonstrated a decreased knowiedge of its accuracy or precision.

"R" When the analyte value reported was unusable. The integrity of the analyte's identification, accuracy, precision, or sensitivity raised significant questions as to the reality of the information presented.

"-" When the analyte value reported was detected. The integrity of the analyte's identification. accuracy, and precision were validated.

\section{Data Validation Summary}

Ejght soil samples were evaluated, with 1259 discrete analyses (i.e., analytes) validated for the project (EPA 1999; EPA 2004). The samples were collected on August 1, 2007. There were 1233 acceptable results out of a total of 1259 . Twenty-six of a total of 587 SVOC resuits were rejected during validation. The rejected results were tentatively identified compounds with estimated results that were less than 10 times the blank result. Note that estimated values are considered acceptable information for data interpretalion. Table 6.1 summarizes the validation results.

Table 6.1. K-1251 Barge Facillty non-radlological validation summary

\begin{tabular}{|c|c|c|c|}
\hline \multirow[b]{2}{*}{ Analyșis type } & \multicolumn{3}{|c|}{ Nomber of results } \\
\hline & $\begin{array}{c}\text { Usable } \\
\text { [U, J, U, and =) }\end{array}$ & Refected (R) & Total \\
\hline PCBs & 72 & 0 & 72 \\
\hline VOCs & 384 & 0 & 384 \\
\hline SVOCs & 561 & 26 & $\$ 87$ \\
\hline Metals & 200 & 0 & 200 \\
\hline Herbicides & 8 & 0 & 8 \\
\hline Total & 1233 & 26 & 1259 \\
\hline \multicolumn{4}{|c|}{ 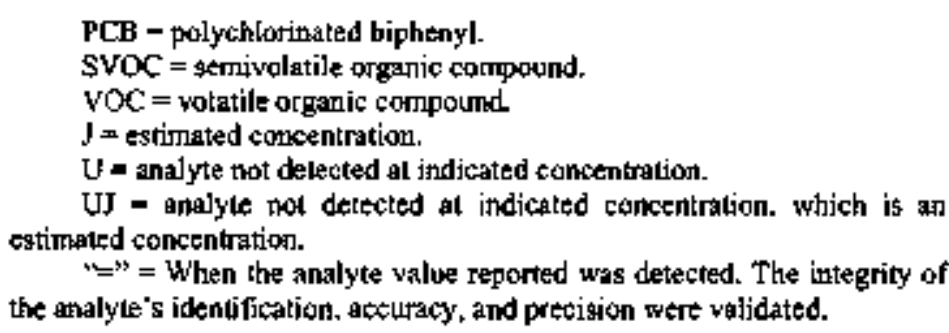 } \\
\hline
\end{tabular}




\section{Results}

The chemical results (see Tables 6.2 through 6.7 ) were interpreted in the risk screen report (see Appendix E). The sampling results are summarized in Table 6.2, below, by analysis type. For each analysis type, the following information is listed:

- the frequency of detection,

- minimum and maximum detected concentrations,

- location(s) at which detected,

- if detected concentrations exceed Zone $1 \mathrm{RLs}$, and

- if detected concentrations exceed preliminary remediation goals (PRGs).

Table 6.2. K-12\$1 Barge Faeility chemical analytleal results summary

\begin{tabular}{|c|c|c|c|c|c|c|}
\hline Analysis type & $\begin{array}{c}\text { Frequency } \\
\text { of } \\
\text { detertions }\end{array}$ & $\begin{array}{c}\text { Minlenum } \\
\text { coneentration }\end{array}$ & $\begin{array}{c}\text { Maximum } \\
\text { cancentration }\end{array}$ & $\begin{array}{l}\text { Locations at } \\
\text { which detected }\end{array}$ & $\begin{array}{c}\text { Exceeds } \\
\text { Zone } 1 \\
\text { remedietion } \\
\text { level? }\end{array}$ & $\begin{array}{c}\text { Prebininary } \\
\text { remedlation } \\
\text { god } \\
\text { exceaded? }\end{array}$ \\
\hline PCB $5(m g / k g)$ & $3 / 72$ & 0.0024 & 0.0073 & 01 and 02 & $\mathrm{No}$ & No \\
\hline VOCs $(\mu \mathrm{g} / \mathrm{kg})$ & $11 / 384$ & 0.297 & 8.59 & 01,02 , and 03 & NA & No \\
\hline SVOCs $(\mu \mathrm{g} / \mathrm{kg})$ & $49 / 561$ & 0.26 & 283 & 01,02, and 03 & $\mathbf{N A}_{\mathrm{A}}$ & No \\
\hline Metals $(\mathrm{mg} / \mathrm{kg}$ ) & $121 / 200$ & 0.0129 & 237,0000 & 01,02 , and 03 & No & No \\
\hline
\end{tabular}

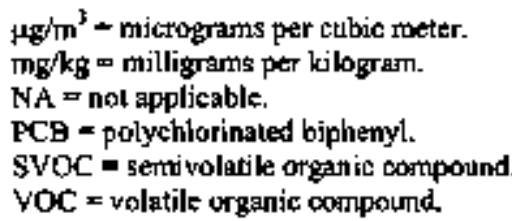

The currenl background evaluation method is based on two documents, one that presents the current background dataset, and a second that outlines the current methodology. The current background dataset consists of the Knox Group and Rome and Chickamauga formation samples from Soil Background Supplemental Data Set for the East Tennessee Technology Park. Oak Ridge Tennessee (DOE/OR/01-2 L05:DD) [DOE 2003b]. The methodology for the comparison to background is presented in Guidance for Comparing Background and Chemical Concentrations in Soil for CERCLA Sites (EPA 540-R-01-003).

There were detected levels for PCBs, VOCs, SVOCs, and metals in soil samples collected at the K-]251 Barge Facility. The chemical concentrations for soils are discussed below.

\section{Chemical Restults}

In the following discussion, the number of detected sample results and the number of sample locations having detected results might not be the sane because samples were collected from multiple depths at all of the sample locations.

PCAs

A total of 72 PCB results were reported, with 3 results (4.17\%) detected. The concentration of the PCB results ranged from 0.0024 to $0.0073 \mathrm{mg} / \mathrm{kg}$ for Aroclor- 1260 (Table 6.3). The detected values were well below the ETTP Zone 1 soil cleanup level for PCBs $(10 \mathrm{mg} / \mathrm{kg})$ that was agreed to by DOE and the 
regulators [Record of Decision for Interim Actions in Zone 1. East Tennessee Technology Park, Oak Ridge, Tennessee, DOE/OR/01-1997/D2 (DOE 2002)]. PCBs have been used for their heat-resistant properties in oils, paints, and other materials subjected to the effects of high temperature. The detected PCB concentrations were detected at locations $0 \mathrm{~L}$ and 02 [Table 6.3]. The detected PCB concentrations were found in samples collected at a depth of 0.0 to $0.5 \mathrm{ft}$ bgs in both the 01 and 02 sample locations and also at a depth of 0.5 to 2.0 at the 02 sample location. The detected PCB results could be due to the former use of various industrial equipment containing oils with PCBs for heat resistance at the K-125l Barge Facility.

Table 6.3. K-1251 Barge Facillty study area polychlorioated blphenyls results

\begin{tabular}{|c|c|c|c|c|c|c|c|}
\hline Analysis type & $\begin{array}{c}\text { Frequency } \\
\text { of } \\
\text { detections }\end{array}$ & $\begin{array}{c}\text { Mbuibum } \\
\text { concentration } \\
\text { (mg/kp) }\end{array}$ & $\begin{array}{c}\text { Maximum } \\
\text { comcentratlon } \\
\text { (mosp) }\end{array}$ & $\begin{array}{c}\text { Loegtifonc at } \\
\text { which } \\
\text { detected }\end{array}$ & $\begin{array}{c}\text { Exceeds } \\
\text { Zone I } \\
\text { remoediation } \\
\text { levelt }\end{array}$ & $\begin{array}{c}\text { Jedestrial } \\
\text { worker soll } \\
\text { prellminasy } \\
\text { remediatlon } \\
\text { roel }\end{array}$ & $\begin{array}{c}\text { Prefiminery } \\
\text { remedtation } \\
\text { goal } \\
\text { exceeded? }\end{array}$ \\
\hline Aroclor-1260 & $3 / 8$ & 0.0024 & 0.0073 & 01 and 02 & No & 7.4 & No \\
\hline
\end{tabular}

${ }^{\circ}$ Based upon U. S. EPA Region 9 published preliminary remediation goals.

$\mathrm{mg} / \mathrm{kg}=$ milligrams per kilogram.

NA = not applicable.

\section{VOCs}

A total of 384 VOC results were reported, with 11 results (2.9\%) detected. The concentrations of the VOC results ranged from $0.297 \mu \mathrm{g} / \mathrm{kg}$ for toluene to $8.59 \mu \mathrm{g} / \mathrm{kg}$ for acetone (Table 6.4). Overall, the concentrations of the VOC results were low with all three sample locations having detected results [Table 6.4]. The detected VOCs included 1,1-dichlorsethenc (locations 01,02 , and 03), acetonc (locations 01,02 , and 03), methylene chloride (locations o2 and 03), and toluene (location 01). Acetone was reported for samples collected at a depth of 0.0 to $0.5 \mathrm{ft}$ bgs at all three locations. This compound was also reported for the 0.5 to $2.0 \mathrm{ft}$ bgs sample at the 02 location, and in the 2.0 to $10.0 \mathrm{ft}$ bgs sample collected at the 01 location. Methylene chloride was detected in the 0.5 to $2.0 \mathrm{ft}$ bgs sample at the 02 location and in the 2.0 to $10.0 \mathrm{ft}$ bgs sample at the 03 location. Toluene was detected in the 2.010 $10.0 \mathrm{ft}$ bgs sample collected al the 01 location. $1, \mathrm{l}$-dichloroethene was detected in the 0.5 to $2.0 \mathrm{ft}$ bgs sample at the 01 and 02 locations, and in the 2.0 to $10.0 \mathrm{ft}$ bgs sample at the 03 location. VOCs are typically industrial solvents or components of fuel. The detected VOC results could be the result of releases related to industrial equipment use and cleaning at the barge facility and/or incidental spills during material transfers at the K-1251 Barge Facility.

Table 6.4. K-12\$1 Barge Facility volstile organic compounds resnlts

\begin{tabular}{|c|c|c|c|c|c|c|c|}
\hline Aaplysls type & $\begin{array}{c}\text { Frequency } \\
\text { of } \\
\text { detections }\end{array}$ & $\begin{array}{c}\text { Mintmam } \\
\text { concentrution } \\
(\mu g / k p)\end{array}$ & $\begin{array}{c}\text { Maxinum } \\
\text { concentration } \\
\text { (up/kg) }\end{array}$ & $\begin{array}{c}\text { Locstions at } \\
\text { whick } \\
\text { detected }\end{array}$ & $\begin{array}{l}\text { Exceeds } \\
\text { Zone 1 } \\
\text { remediation } \\
\text { levecl? }\end{array}$ & $\begin{array}{c}\text { Indwstrbal } \\
\text { worker soil } \\
\text { preliminary } \\
\text { remediotion } \\
\text { goal‘ }\end{array}$ & $\begin{array}{c}\text { Prelliminary } \\
\text { reaceditation } \\
\text { gool } \\
\text { exceeded? }\end{array}$ \\
\hline 1.1-Dichloroethere & $3 / 8$ & 0.595 & 0.955 & 01,02 , and 03 & NA & 413,000 & No \\
\hline Acetothe & $5 / 8$ & 2.28 & 8.59 & 01,02 , and 03 & NA & $\$ 4,000,000$ & No \\
\hline Methylene chloride & $2 / 3$ & 2.35 & 4.13 & 02, and 03 & NA & 205,000 & $\mathbf{N o}$ \\
\hline Toluene & ]$/ 8$ & 0.297 & 0.297 & 01 & NA & $2,200,000$ & No \\
\hline
\end{tabular}

${ }^{\circ}$ Based upon U. S. EPA Region 9 published preliminaty temediation goals. $\mu \mathrm{g} / \mathrm{kg}=$ mictograms per kilognam.

NA $=$ not applicable. 


\section{SVOCs}

A total of 561 SVOC results were reported, with 49 results (8.7\%) detected. As stated eariier, 26 SVOC results were rejected during validation and, therefore, were not used. The concentrations of the SVOC results ranged from $0.26 \mu \mathrm{g} / \mathrm{kg}$ for 1,4 -dichlorobenzene to $283 \mu \mathrm{g} / \mathrm{kg}$ for fluoranthene (Table 6.5 ). SVOCs are used in various industries and tound in lubricants and as components of fuel. The detected SVOC results were found at all three sample locations and at ail depths. The greatest frequency of detects occurred in the surface $(0.0 \mathrm{to} 0.5 \mathrm{ft}$ bgs) and shaliow subsurface $(0.5$ to $2.0 \mathrm{ft}$ bgs) soil samples. Ten of the bighest SVOC results came from the surface soil sample $(0.0$ to $0.5 \mathrm{ft}$ bgs) at location 03 . Sample jocation 03 is located adjacent to the southeast side of the concrele pad (Fig, 6.1). The detected SVOC results could be the result of the use of diesel fuel and/or lubricating oils at the K-1251 Barge Facility.

Table 6.5. K-1251 Baree Factlity stemivolatile organic compounds results

\begin{tabular}{|c|c|c|c|c|c|c|c|}
\hline Analysis type & $\begin{array}{c}\text { Frequentrey } \\
\text { of } \\
\text { detections }\end{array}$ & $\begin{array}{c}\text { Minkmum } \\
\text { comcentration } \\
\text { (ug/kg) }\end{array}$ & $\begin{array}{c}\text { Maximum } \\
\text { comcentration } \\
(\mu \mathrm{g}) \mathrm{kg})\end{array}$ & $\begin{array}{l}\text { Locations a1 } \\
\text { which detected }\end{array}$ & $\begin{array}{l}\text { Eroesis } \\
\text { Zone } 1 \\
\text { remeditition } \\
\text { level? }\end{array}$ & $\begin{array}{l}\text { Industrial } \\
\text { worker soil } \\
\text { prefiningary } \\
\text { remeditition } \\
\text { gogr" }\end{array}$ & $\begin{array}{l}\text { Preliminary } \\
\text { remedlation } \\
\text { soal } \\
\text { exceeded? }\end{array}$ \\
\hline 1,4-Diehlorobenzenc & $8 / 8$ & 0.26 & 0.859 & 01,02, and 03 & $\mathrm{NA}$ & 78,700 & No \\
\hline Acenaphthene & $2 / 8$ & 11.3 & 24.2 & 03 & NA & $29,200,000$ & No \\
\hline Authracene & $3 / 8$ & 18.7 & 65.5 & 02 and 03 & NA & $238,000,0000$ & No \\
\hline Benz(a)arthracene & $3 / 8$ & 59.2 & 129 & 02 and 03 & NA & 21,000 & No \\
\hline Benzo(a)pyrene & $4 / 8$ & 66.3 & 139 & 01,02 . and 03 & NA & 2,100 & No \\
\hline Benzo(b)fluorarthene & $3 / 8$ & 70.5 & 213 & 01 and 02 & NA & 21,000 & No \\
\hline Elenzo( $k$ ) fluoranthene & $1 / 8$ & 26.8 & 26.8 & 01 & NA & 211000 & No \\
\hline Carbazole & $1 / 8$ & 55.3 & 55.3 & 03 & NA & 862,000 & No \\
\hline Chrysene & $3 / 8$ & 52.4 & 119 & 02 and 03 & NA & $2,100,000$ & No \\
\hline Fluoranthene & $7 / 8$ & 14 & 283 & 01,02 , and 09 & NA & $22,000,000$ & No \\
\hline Flyotene & $2 / 8$ & 13.3 & 30]$. & 03 & NA & $26,300,000$ & No \\
\hline Indenol $(I, 2,3-\mathrm{cd}$ )pyrene & $5 / 8$ & $12 \mathrm{~B}$ & 163 & 01,02 , and 03 & NA & 21,000 & No \\
\hline Naphthalente & $1 / 8$ & 13.5 & 13.5 & 02 , and 03 & NA & ] 87,000 & No \\
\hline Рутепе & $6 / 8$ & 21.5 & 221 & 01,02 , ard 03 & NA & $29,100,000$ & No \\
\hline
\end{tabular}

' Based upon U. S Envitormental Protecion Agency Reglon 9 published predimitary remediation goals $\mu \mathrm{g} / \mathbf{k} \mathbf{y}=$ mucrograms per kilogram. NA = not applkable

\section{Metals}

A totat of 200 metal results were reported, with 121 results $(60.5 \%)$ detected. The concentrations of the metal results ranged from $0.0129 \mathrm{mg} / \mathrm{kg}$ for mercury to $237,000 \mathrm{mg} / \mathrm{kg}$ for calcium (Table 6.6). Zone 1 cleanup levels have been established only for arsenic, beryltium, and mercury. The detected arsenic, berylijum, and mercury results did not exceed Zone 1 RLs (see Table 6.2). All sample jocations wetc found to bave detected metais results, which is to be expected because soil generally bas a measurable content of metals in nature. There is no evident correlation between sample location and elevated metal results. The highest metal cesults were for the macronutrient elements aluminum, calcium, iron, magnesium, and potassium, which are all naturally occurring. No metal results were found to exceed industrial worker soil PRGs. Five metals were found at concentrations above background concentrations established for the ETTP. These metals include antimony, barium, cadmium, lead, and zinc. With the exception of lead, all of the detected metals concentrations above background were found in samples 
collected from surface sols (0.0 to $0.5 \mathrm{ft}$ bgs) or the shallow subsurface sols (0 5 to $20 \mathrm{ft}$ bgs) Lead exceeded background at all three sample depths at the 0I location However, the subsurface soll sample from the 20 to $10.0 \mathrm{ft}$ bgs depth at location 01 exceeded background by less than a factor of 2 . As mentioned previously metals ate ubigutous in natural solts, and given the nature of the activitues conducted at the barge facility and the presence of scattered scrap metal objects thoughout the study area. It is not unexpected that slightly elevated metal concentrations occur w the shallow sols.

Table 6.6. K-1251 Barge Facility metals resalts

\begin{tabular}{|c|c|c|c|c|c|c|c|}
\hline $\begin{array}{c}\text { Analysis } \\
\text { type }\end{array}$ & $\begin{array}{c}\text { Frey uétey } \\
\text { of } \\
\text { detections }\end{array}$ & $\begin{array}{c}\text { Minisnum } \\
\text { concentration } \\
\text { (mglkg) }\end{array}$ & $\begin{array}{c}\text { Maximam } \\
\text { concestration } \\
\text { (Ime/kg) }\end{array}$ & $\begin{array}{c}\text { Locations at which } \\
\text { defected }\end{array}$ & $\begin{array}{c}\text { Exceeds } \\
\text { Zone I } \\
\text { remediation } \\
\text { levels? }\end{array}$ & $\begin{array}{c}\text { Industrial } \\
\text { worker woil } \\
\text { preibmiatiry } \\
\text { remediathom } \\
\text { enald }\end{array}$ & $\begin{array}{c}\text { Preliminary } \\
\text { remeedlatlon } \\
\text { gonl } \\
\text { exceeded? }\end{array}$ \\
\hline Alummum & 88 & 3,450 & 12,400 & 01,02 and 03 & $N_{A}$ & 921,000 & No \\
\hline Antımony & 48 & 374 & 126 & 01 and 03 & NA & 409 & No \\
\hline Arsenic & 818 & 232 & 541 & 01,02 , and 03 & No & 16 & No \\
\hline Banum & $8 / 8$ & 245 & $15 !$ & 01,02 , and 03 & $\mathbf{N A}$ & 66,600 & No \\
\hline Beryllium & 818 & () 279 & 123 & 01,02 , and 03 & No & 1,940 & Nọ \\
\hline Borots & $8 / 8$ & 218 & 254 & 01,02 , and 03 & $\mathrm{NA}$ & 200,000 & No \\
\hline Cadmium & $4 / 8$ & 0151 & 153 & 01 and 02 & NA & 451 & No \\
\hline Calcuum & $8 / B$ & 17,700 & 237,000 & 01,02, and 03 & NA & $\mathbf{N A}$ & $\mathrm{NA}$ \\
\hline Chrorsuturs & $8 / 8$ & 115 & 899 & 01,02 , and 03 & $\mathrm{NA}$ & 4,500 & No \\
\hline Coball & $8 / 8$ & 308 & L0! & 01,02 , and 03 & NA & 13,300 & No \\
\hline Copper & $8 / 8$ & 795 & 367 & 01,02 , and 03 & NA & 40,900 & No \\
\hline Iton & $8 / 8$ & 9,480 & 21,900 & 01,02 , and 03 & NA & 306,400 & No \\
\hline Lead & $8 / 8$ & 241 & 2,260 & 01,02 , and 03 & $N_{A}$ & $\mathrm{NA}$ & $\mathrm{NA}$ \\
\hline Magrtesium & $8 / 8$ & 1,580 & 7,6000 & 01,02 , and 03 & $\mathrm{NA}$ & NA & NA \\
\hline Manganese & $8 / 8$ & 153 & 561 & 01,02 , and 03 & $\mathrm{NA}$ & 19,500 & No \\
\hline Mercury & 88 & 00129 & 00326 & 01,02 , and 03 & No & 306 & $N_{0}$ \\
\hline Nycke] & $8 / 8$ & 79 & 203 & 01,02 , and 03 & NA & 20,400 & No \\
\hline Polassium & $8 / 8$ & 514 & 1,530 & 01,02 , and 03 & NA & NA & NA \\
\hline Selenנum & $1 / 8$ & 0944 & 0944 & 01! & NA & 5.100 & No \\
\hline Silver & $0 / 8$ & NA & NA & NA & NA & 5,100 & No \\
\hline Sodium & $6 / 8$ & 835 & 637 & 01,02 , and 03 & NA & NA & $\mathrm{NA}$ \\
\hline Thallum & $0 / 8$ & NA & NA & NA & NA & 67 & No \\
\hline Vanadnum & 88 & 48 & 182 & 01,02 , and 03 & NA & 1,020 & No \\
\hline Zinc & $8 B$ & 285 & 581 & 01,02 , and 03 & NA & 306,400 & No \\
\hline
\end{tabular}

${ }^{4}$ Based upon U S EPA Region 9 publıshed prelımmary temediation goals

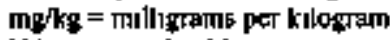

NA - toct applicable

\subsubsection{Concrete Pad Sample Results}

Two samples of the concrete pad were collected un August 2007 al the K-1251 Barge Facility. These samples, collected from the top $3 \mathrm{in}$. of the concrete surface, were analyzed for PCBs The results, sumnarized in Table 6.7, indicate that PCBs were detected in the concrete. Aroclor-1254 and Aroclor- 1260 were detected at concentrations rangung from 0002 to $0.0067 \mathrm{mg} / \mathrm{kg}$. These concentrations are well below the established RL of $10 \mathrm{mg} / \mathrm{kg}$ for PCBs in Zone 1 of the ETTP and the industrial worker PRG. As previously mentioned, PCBs were commonly used for their heat-resistant properties in ouls, pants, and other matenals. The indugtnal bature of the activiues conducted at the barge facility likely account for the presence of PCBs on the concrete pad 
Table 6.7. Aaglytical resulcs for concrete samples collected at the K-1251 Barge Facility

\begin{tabular}{|c|c|c|c|c|c|c|c|}
\hline $\begin{array}{c}\text { Analysis } \\
\text { type }\end{array}$ & $\begin{array}{c}\text { Frequency } \\
\text { of } \\
\text { detextions }\end{array}$ & $\begin{array}{l}\text { Minimum } \\
\text { concentratlog } \\
\text { (mo/kg) }\end{array}$ & $\begin{array}{c}\text { Maximum } \\
\text { concentration } \\
\text { (me/kg) }\end{array}$ & $\begin{array}{l}\text { Locations } \\
\text { at which } \\
\text { detected }\end{array}$ & $\begin{array}{c}\text { Exceeds } \\
\text { Zone I } \\
\text { remcdlation } \\
\text { levelk? }\end{array}$ & $\begin{array}{c}\text { Industrial } \\
\text { worker soil } \\
\text { prellaninary } \\
\text { remedlatilon } \\
\text { gosf" }\end{array}$ & $\begin{array}{l}\text { Prellminary } \\
\text { remedlatior } \\
\text { goal } \\
\text { excetede }\end{array}$ \\
\hline PCB-I254 & $2 / 2$ & 0.002 & 0.0067 & 04 and 05 & No & 7.4 & No \\
\hline PCB-1260 & $1 / 2$ & $0.004 i$ & 0.0041 & 04 & No & 7.4 & No \\
\hline
\end{tabular}

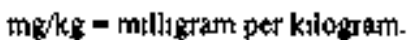

PCE = polychlonnaled biphenyl.

\subsection{RADIOLOGICAL SURVEYS AND SAMPLING}

This section presents and diseusses both historical and recent radiological survey data and the radiological soil sampling results collecled from the study area. The historical survey data are presented, followed by a discussion of the survey methodology and results used to supplement the hislorical data. The final subsection presents a summary of the 2007 soil sample data.

The process history of the ETTP Site indicates uranium (natural, depleted, and/or enriched) is the most prominent radiological contaminant potentially present in the K-1251 land parcel as a result of tracking contamination from on-site buildings, from environmental release, or from handling $U_{6}$ cylinders at the barge-umloading facility. Uranium-235 entrichnent levels from optrations since the carly $1960 \mathrm{~s}$ are expected between 0.2 and $5.0 \%$. Potential contamination would be expected to be by enrichments of less than $3 \%{ }^{4}$

Other radionuclides detected on-site at ETTP are ${ }^{60} \mathrm{Co},{ }^{137} \mathrm{Cs}_{1}{ }^{90} \mathrm{Sr}_{4}{ }^{297} \mathrm{~Np}_{4}{ }^{99} \mathrm{~T} \mathrm{c}_{\text {, and }}$, ${ }^{20 / 239290} \mathrm{Pu}$. These other radionuclides originated from the introduction of contaminated materials from ORNL and/or from the Hanford and Savannah River reactor tetums program and could have been present in UF $_{6}$ cylinder heels.

In summary, as will be described below, the radiological survey results show that all surface survey readings are less than the DCGLs. Results of the radiological soil analyses show that no residual contamination in excess of the Zone 1 remediation goals was found. (Although K-1251 is not in Zone l. the Zone 1 remediation goals were used for comparative purposes.).

\subsubsection{Radiological Surveys}

The K-125l parcel consisted of one land survey unit (LSU) and one exterior survey unit (ESU). The classification of the survey units and the performance of the survey were completed in accordance with ETTP Radiation Control (RADOON) pracedures ${ }^{5}$ and the survey design document ${ }^{6}$ and are discussed in the survey plan (see Appendix C). The LSU was classified as a Class 2 survey unit and consisted of the area enclosed by the fence adjacent to the Clinch River and the access road. Historical documentation indicates this area (except for the access road) was once utilized as a $\mathrm{UF}_{6}$ cylinder storage area. There are

\footnotetext{
"Contracted Health Physics Tectricician Training handouts, K-25 Site, 1993.

"Primarily EH-45 16, "Radioactive Contamination Control and Monitoring." found in BJC-EH-4000, Ractiation Protection Program Description for Bechtel Jacobs Company LLC. Oak Ridge. Tennessee.

'Design of Radiological Survey and Sampling to Support Titte Transfer or Lease of Property on the Department of Energy Oak Ridge Reservation, BJC/OR-554-Rl, Becblel Jacobs Company LLC, Dak Ridge, TN, August 2006.
} 
no tata indicating that spills or accidental releases occurred in this area; thus, contanination levels were not expected to exceed the derived concentration guideline level (DCGL). The ESU, a concrete pad, was classified as a Class 2 survey. Historical knowledge indicates that this area may have once been posted as a radiological contamination area. However, since it has been downposted, no residual contamination in excess of the DCGL was expected

\subsubsection{Historical surveys}

A search of the Bechtel Jacobs Company LLC (BIC) RADCON electronic survey data collected between 1996 and 2006 showed one characterization survey associated with the $\mathrm{K}-[25]$ facility. The survey, performed in 2000 (20000216KA36147001), consisted of an area survey with a sodiom iocide (Nal) detector. The survey results revealed all areas to be less than twice background. Only wo locations were time counted. The highes 1 coutnt rate was obtained in the dilch on the north and east sides of the fenced area where a count rate of 1000 counts per minute (cpm) was obtained (background was $5400 \mathrm{cpm}$ ). No other radiological survey data were found.

\subsubsection{2007 Exterior survey unit}

The Class 2 ESU consisted of the concrete pad. One exterior radiological surface survey was conducted in the footprint (survey number 20070710WCUDESK001). The survey was performed on July 12, 2007, in accorcance with the survey plan (Appendix C). The slab was scan-surveyed over the accessible area that was not covered by moss, weeds, and vegetation with $50 \%$ coverage. Twelve measurements of total and removable activity were taken (alpha and beta-ganma) at locations given by the fixed survey grid provided in the survey plan. A summary of the survey results is shown in Table 6.8.

All readings taken in the ESU were less than 1250 disintegrations per minute per 100 square centimeters $\left(\mathrm{opm} / 00 \mathrm{~cm}^{2}\right)$ total activity. Because all results were less than the respective screening levels, no further statistical analysis was performed. Based on an inspection of the individual surveys, including quality assurance/quality control surveys, all total actjvities were less than I dpm/100 $\mathrm{cm}^{2}$ total alpha and less than $91 \mathrm{dpta} / 100 \mathrm{~cm}^{2}$ total beta-gamma, with all removable contamination results less than $4 \mathrm{dpm} / 100 \mathrm{~cm}^{2}$ removable alpha and less than $15 \mathrm{dpm} / 100 \mathrm{~cm}^{2}$ removable beta-gamma. The maximum tissue-equivalent dose rate was $4 \mu \mathrm{rem} / \mathrm{hour}$, which is in the background range for the site.

Results of the radiological surveys performed in the study area indicate that the concrete surfaces are below the DOE surface contamination limits and within the acceptable dose-equivalent rate range for exterior surfaces. Because all results were less than the DCGL, the survey units can be released from a surface contamination slandpoint.

\subsubsection{Land survey unit}

The Class 2 LSU consisted of the area enclosed by the fence adjacent to the Clinch River and the access road. A separate sampling plan was executed to evaluate soil contamination. Many of the radionuclides found in the Oak Ridge Reservation have natural background concentrations; therefore, backgound subtraction will be required for all direct field measurements and laboratory analyses. Some comparison to backeround levels is reguired for the scanning because only a gross signal was measured. 
Tible 6.8. Summary of contamination and dose rates

\begin{tabular}{|c|c|c|c|c|c|c|c|c|c|c|c|}
\hline \multirow[b]{2}{*}{ Losation } & \multicolumn{4}{|c|}{ Alplas tutal } & \multicolumn{2}{|c|}{ Alpha remuvable } & \multicolumn{2}{|c|}{ Betz-gamma lotal } & \multicolumn{2}{|c|}{ Beta-gamma removable } & \multirow{2}{*}{$\begin{array}{c}\text { Dose equlvalent rate } \\
(\mu \mathrm{rem} / \mathrm{h})\end{array}$} \\
\hline & & Min. & & Max, & Min. & Mox. & Min. & Max. & Min. & Max. & \\
\hline \multicolumn{12}{|c|}{ Euterlor survey unifs - Cless 3} \\
\hline ESU I & 8 & .23 & 4 & $\mathbf{0}$ & 4.43 & 3.49 & \begin{tabular}{l|l}
$<54234$ \\
\end{tabular} & 90.39 & .313 & 141 & 4 \\
\hline DOE contamutation limirs & & & & 5000 & & 1000 & & 5000 & & 1000 & 20,000 \\
\hline
\end{tabular}

Noter. All regdings are in tutils of disintegrations pet minule (dpm) $100 \mathrm{~cm}^{2}$.

A "ch preceding a value indicates that the result cannot be disingunshed from backgtound at the $95 \%$ confidence level.

This table toes not unclude fesulls from quality assurancedqualnty contro] surveys.

DOE = U S. Departmenl of Entrgy

ESU = extenor survey unst.

$\mathrm{NR}=$ not rectorded 
One land radiological survey was conducted in the footprint (survey number 20070725 WCUDESK002). The surveys of the fixed grid assessment points were performed on July 25 , 2007 , in accordance with the survey plan (see Appendix C).

NaI walkover survey judgment scans were performed according to the survey plan (Appendix C). Emphasis was placed on road bed areas, suspect areas of soil or vegetation discoloration, and other areas based on professional judgnent. Nal survey measurements were performed at the fixed-grid assessment points. No anthropogenic, groundwater nunof, and sediment collection areas were recognized during the NaI walkover, and no scan areas were detemined to bave elevated readings. A 10 -ft-diameter surface area was scanned at each of the fixed grid points with the $\mathrm{Nal}$ detector. The measurements recorded at each point included only timed, l-min-count $\mathrm{Nal}$ and dose-rate measurements at the location of the highest scan reading.

Because the DCGLs for surface measurements do not apply to soil areas and soil samples were collected in these areas for analysis, direct readings are not used in the dose and risk assessments for soil areas. Therefore, no upgrade of any LSUs would be made based on the timed NaI measurements. However, upgrades could be necessary based on the results of the soil sampling and analysis discussed below,

The results of the fixed-timed $\mathrm{NaI}$ measurements are shown in Table 6.9. A total of $14 \mathrm{NaI}$ measurements were made at fixed grid locations in LSU 1 per Appendix C, Fig. C.2. No NaI measurements were greater than two times a field-determined background appropriate for the geological and topographical conditions. Nal background count rates ranged from $3296 \mathrm{cpm}$ is $6490 \mathrm{cpm}$ Based on an inspection of the individual surveys, all $\mathrm{Nal}$ readings were less than $7162 \mathrm{cpm}$. The maximum tissue-equivalent dose rate was 6 uren/hour, which is in the background range for the site.

Talble 6.9. Fixed-timed measurements

\begin{tabular}{|c|c|c|c|c|}
\hline Location & $\begin{array}{c}\text { No. of } \\
\text { Mensurements }\end{array}$ & $\begin{array}{c}\text { N*I } \\
\text { Min. cpun }\end{array}$ & $\begin{array}{c}\text { NaI } \\
\text { Mar. cpm }\end{array}$ & $\begin{array}{c}\text { Dose equivadent } \\
\text { (ㅆrem/u) }\end{array}$ \\
\hline LSU 1 Grid APG & 14 & 3096 & 7162 & 3 to 6 \\
\hline
\end{tabular}

Nofe: Sodiun iodide ( $\mathrm{Na}$ ) fixed-fimed megsurements are reponed in counts per mimute (cpm) and are not backeroundcomected.

AP $=$ assesstment point.

LSU = land survey unit.

\subsubsection{Radiological Sampling}

\subsubsection{Historical samples}

A search of the OREIS database showed data are available from only one historical soil sample within the K-I251 foptprint. The sample from station RAD436 was collected in I994 and quantified for radionuclides. The results are shown in Table 6.10. All detected tadionuclide results were below their respective background values. 
Table 6.10. Hlstorleal radfological soil sample data from K-1251

\begin{tabular}{|c|c|c|c|c|c|c|c|c|c|c|c|c|c|c|c|c|}
\hline Sample ID & $\begin{array}{c}\text { Sample } \\
\text { depth (ft) }\end{array}$ & $\begin{array}{l}\mathrm{S}^{21} \mathrm{Am} \\
(\mathrm{pCO} / \mathrm{g})\end{array}$ & $\begin{array}{c}\mathrm{Co}^{4} \\
\left(\mathrm{pCv}_{\mathrm{g}}\right)\end{array}$ & $\begin{array}{c}\text { ds'Cs } \\
\text { (pClig) }\end{array}$ & $\begin{array}{c}{ }^{3+} \mathrm{Np} \\
\left(p C f^{\prime} g\right)\end{array}$ & 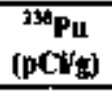 & $\begin{array}{l}\cos ^{40} \mathrm{Pu} \\
(p<\mathrm{C}) \mathrm{s}\end{array}$ & $\begin{array}{l}12 \mathrm{Rs} \\
\left(\mathrm{pC} \mathrm{C}_{\mathrm{g}}\right)\end{array}$ & $\begin{array}{c}{ }^{6} T_{\varepsilon} \\
\text { (pCifg) }\end{array}$ & $\begin{array}{c}{ }^{2} 28 \mathrm{Th} \\
(\mathrm{pCL} / \mathrm{g})\end{array}$ & $\begin{array}{c}{ }^{290} \mathrm{Th} \\
\text { (pCW/B) }\end{array}$ & $\begin{array}{c}{ }^{232} \mathrm{Th} \\
\text { (pCVg) }\end{array}$ & $\begin{array}{c}\text { 2)+Th } \\
\text { (pClfg) }\end{array}$ & $\begin{array}{c}{ }^{23} \mathrm{~d} \\
(\mathrm{pCl} / \mathrm{g})\end{array}$ & 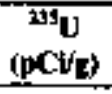 & 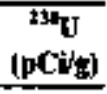 \\
\hline RAD436 & $0-05$ & $\mathrm{NA}$ & $0004 \mathrm{U}$ & 0397 & $002 \mathrm{U}$ & $000 \mathrm{U}$ & $0009 \mathrm{U}$ & 021 & $000 \mathrm{U}$ & 0268 & 095 & 0309 & $044 \mathrm{U}$ & 0303 & 0091 & 032 \\
\hline
\end{tabular}

NA = data not avalable

Bold $t$ detected value exceeds radrousclide backgromind data set Backeround concentracion as defined by Bechtel Jacobs Company LLC in DOEE 2003 7le background dala sel that the

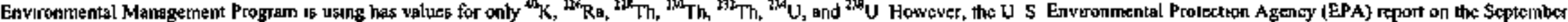

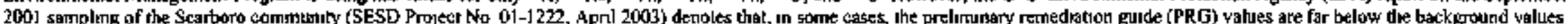

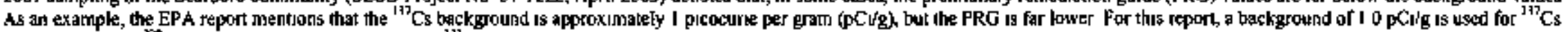

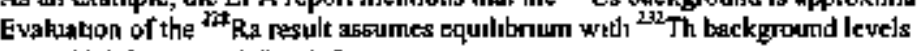

Valudatoon quälıfier defhucoons

derotes the analyte was pobjbucly identefied, the assoctated result t5 the approxumate conceruration of the anslyte in the sample

$U$ denctes the minalyte was analyzed for, but was nol delected above the reporled sample quantitation lamit

UJ deareses the analyte was not detected above the reported delectırn limit, which is approxınaied due to quality deficiency 


\subsubsection{2007 Soll Samples}

The 2007 sample results described below are from the judgmental soil samples that were collected in accordance with the SAP included in Appendix B. In order to meet data requirements for the risk screening, additional samples were needed to supplement the existing data. Based on the bistory of the K-125 I Barge Facility, if any radiological contamination was present, it was expected to be localized near the crane pad. The three sampling localions indicated in Fig. 6.1 were selected on a judgmental basis. The concrete was not sampled because any contamination would be assumed to be on the surface and not at depth. Therefore, surface limits rather than concentration limits apply.

All samples collected from the sampling locations indicated below were quantified for tolal activity, isotopic uranium, ${ }^{99} \mathrm{Tc},{ }^{90} \mathrm{Sr}$, gamma-emitting issotopes (including but not limited to ${ }^{60} \mathrm{Co},{ }^{137} \mathrm{Cs}$, ${ }^{294 m} \mathrm{~Pa}$, and ${ }^{234} \mathrm{Th}$ ), transuranic isotopes (i.e., ${ }^{293} \mathrm{~Np},{ }^{238} \mathrm{Pu},{ }^{239} \mathrm{Pu}$, and $\left.{ }^{241} \mathrm{Am}\right)$, and isotopic thorium $\left({ }^{228} \mathrm{Th},{ }^{234} \mathrm{Th}\right.$, and ${ }^{232} \mathrm{~Tb}$ ). ln addition, ${ }^{226} \mathrm{Ra}$ and ${ }^{228} \mathrm{Ra}$ were reported based on the measurement of their progeny from the gamma spectrometry analyses. A total of eight soil samples from the three locations were sampled in the study area for radiological analysis during this effort to determine the presence of contamination as shown in Tabje 6.11. An equipment rinsate blank mentioned in the SAP was not collected due to the sampling method used. During the data validation process, laboratory data were assigned approptiate data validation flags. Refer to Sect. 6.1.2.1 for the validation flags and their definitions.

Table 6.11. Summary of K-1251 surface and subsurface soil simples for radiotogiest

anolyses

\begin{tabular}{|c|c|}
\hline Semiple nomber & Sample depth \\
\hline NS-01-01-125I & $0.0-0.5$ \\
\hline NS-01-02-125i & $0.5-2.0$ \\
\hline NE- $01-03-125 i$ & $2.0-10,0$ \\
\hline NS-02-01-12S! & $0.0-0.5$ \\
\hline$N S-02-02-125 t$ & $0.5-2.0$ \\
\hline NS- $-03-01-125]$ & $0.0-0.5$ \\
\hline NS-03.02-125 & $0.5-2.0$ \\
\hline $\mathrm{NS}-03-03-1251$ & $2.0-10.0$ \\
\hline
\end{tabular}

\subsubsection{Sample data anglysis}

\section{Data Validation Summary}

Eight surface, near-surface, and subsurface soil samples wete validated. During the data validation process, laboralory data were assigned appropriate data validation flags. Refer to Sect. 6.I.2.1 for the validation flags and their definitions. All individual total activity results were qualified as unusable (R) Jue to a negative bias resulting from improper background subtraction. These are not of concern because the results are only used for intercomparisons during the data validation process and ate not critical to the risk assessment. All thorium and uranium isotopic tesults by alpha spectroscopy were qualified as estimated ( $J$ ) due to the uncertainty in the chemical recovery being greater than the allowable linut and all ${ }^{90} \mathrm{Sr}^{237}{ }^{230} \mathrm{~Np},{ }^{238,23 \% / 24010} \mathrm{Pu},{ }^{241} \mathrm{Am}$, and total activity results being qualified as estimated (J) since the leaching procedure may not remove all of the analytes of concem from the sample matrix, causing an unknown amount of negative bias on the results as shown on Table 6.12. In addition, the ${ }^{226} \mathrm{Ra}$ results should be considered estimated since they assume equilibrium with a radon daughter that may not be in equilibrium due to emanation. Note that estimated values are considered acceptable information for data interpretation. 
Table 6.12. 2007 Radiological soil sample data from the K-I25I Barge Facility

\begin{tabular}{|c|c|c|c|c|c|c|c|c|c|c|c|c|c|c|c|}
\hline & 8 & (g) & $\begin{array}{l}{ }^{\circ} \mathrm{Cu} \\
\mathrm{C}(\mathrm{g})\end{array}$ & $\begin{array}{c}{ }^{137} \mathrm{Cs} \\
\text { (focitg) }\end{array}$ & 5) & (pisu & $\begin{array}{l}\text { 2pmes } \mathrm{Pu} \\
(\mathrm{pCH} / \mathrm{g})\end{array}$ & $\begin{array}{l}\mathrm{nin}_{\mathrm{sr}} \\
(\mathrm{pCI} / \mathrm{g})\end{array}$ & Tttg & Th' & 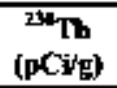 & a) & (i) & ${ }^{2 x} \mathrm{U}$ & $\begin{array}{l}{ }^{3 *} \mathrm{U} \\
\mathrm{pCl}(\mathrm{g})\end{array}$ \\
\hline & & & & & & & & & & & & & & UJ & S65 J \\
\hline & & & & & & & & & & & & & & & \\
\hline & & U & -0.00 & $0.00429 \mathrm{U}$ & -0.00 & uJ & & $0.403 \mathrm{UJ}$ & $.44 \mathrm{U}$ & & $0.876 I$ & & $41 \mathrm{~J}$ & 0.085 & $696 \mathrm{~J}$ \\
\hline & & $\mathrm{UJ}$ & $0.00113 \mathrm{u}$ & & & & & -1.8 & $248 \mathrm{U}$ & & & & & s. & $1.56 \mathrm{~J}$ \\
\hline & & UJ & $A$ & 11 & J & -0 & 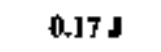 & .1. & $\mathrm{U}$ & $\mathrm{J}$ & $.15 \mathrm{~J}$ & & $52 \mathrm{~J}$ & $104 \mathrm{~J}$ & .0l J \\
\hline & & $0255 \mathrm{UI}$ & $0.00836 \mathrm{U}$ & & & $7 \mathrm{UJ}$ & $16 \mathrm{UJ}$ & t.71 us & $0.511 \mathrm{U}$ & J & $0.536 \mathrm{~J}$ & J & $.843 \mathrm{~J}$ & נ.0.005 & $0.458 \mathrm{~J}$ \\
\hline & & & & & & $-0,0508 \mathrm{UJ}$ & $-0.0613 \mathrm{UI}$ & & & 0.75 & & & J I & & $612 \mathrm{~J}$ \\
\hline $03-03-1251-04$ & 10 & 0.0335 UJ & $0.00139 \mathrm{U}$ & .016 & נلט & $0.0261 \mathrm{UJ}$ & 0 UI & $-0.836 \mathrm{UJ}$ & $2.55 \mathrm{U}$ & l.1 J & $1.02 \mathrm{~J}$ & $0.871 \mathrm{~J}$ & $0.984 \mathrm{~J}$ & $0.031 \mathrm{UJ}$ & $0.733 \mathrm{~J}$ \\
\hline
\end{tabular}

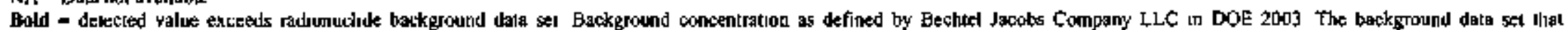

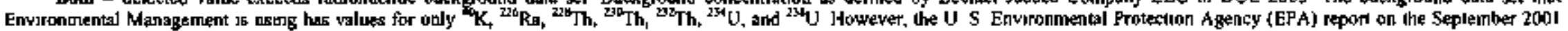

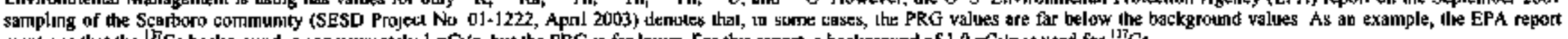

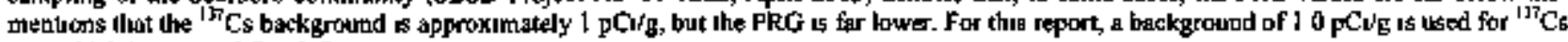

Valndauon qualifier defintions

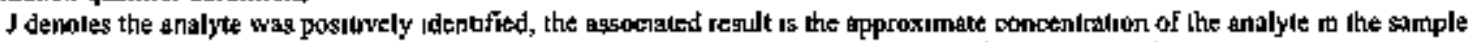

U denotes the analyte was analyzed for, bul was not detected above the reported sample ouantiauno limut

UJ denoles the analyte was not detected above the reporied deateiron lomil, whech is approximaled due to quality deficlency 
The sum of the analytical results, including daughters assumed in equilibrium and ${ }^{40} \mathrm{~K}$ results found in the raw data, was compared with the total actjvity results for each sample. The comparison showed agreement with all samples.

\section{Resnits}

The resuits are summarized along with historical data in Table 6.13. For each anajysis type, the following information is listed:

- frequency of detection above backeround scretning level,

- minimum and maximum concentrations.

- arithmetic mean,

- comparison to Zone 1 RLs, and

- comparison to PRG calculated at the $10^{-5}$ risk level.

The current background evaluation method is based on DOE (2003) and EPA (2002b). Althongh some individual semple results for certain radionuclide analytes $\left({ }^{137} \mathrm{Cs}^{60}{ }^{60} \mathrm{Co},{ }^{239} \mathrm{Pu}^{226}{ }^{226} \mathrm{Ra},{ }^{230} \mathrm{Th}_{r}{ }^{234} \mathrm{U}\right.$, ${ }^{235} \mathrm{U}$, and $\left.{ }^{238} \mathrm{U}\right)$ exceeded their background values and some $\left({ }^{137} \mathrm{Cs},{ }^{226} \mathrm{Ra},{ }^{228} \mathrm{Ra},{ }^{228} \mathrm{Th},{ }^{233} \mathrm{Th}\right)$ exceeded the PRG, as shown in Table 6.I3, no individual tesulis wete greater than the Zonc 1 maximum RLs and no averages were above average RLs. Therefore, no residual contamination in excess of the Zone 1 remedjation goals was found. (Although $\mathrm{K}-125 \mathrm{l}$ is not in Zone $\mathrm{l}$, the Zone l remedial goals are used for comparison pupposes.) 
Table 6.13. K-1251 summary statkstles for radionucldes with historical data

\begin{tabular}{|c|c|c|c|c|c|c|c|c|c|c|c|c|}
\hline Analyte & $\begin{array}{c}\text { Prequency } \\
\text { of } \\
\text { detections }\end{array}$ & $\begin{array}{l}\text { Máninan } \\
\text { detected } \\
\text { concentration } \\
\text { (pCV) }\end{array}$ & $\begin{array}{c}\text { Marimiani } \\
\text { datected } \\
\text { concentration } \\
\text { (pCW' }\end{array}$ & $\begin{array}{l}\text { Average } \\
\text { detected } \\
\text { concentruttion } \\
\text { (pCLg) }\end{array}$ & $\begin{array}{l}\text { Background } \\
\text { reference } \\
\text { level| (pcils) }\end{array}$ & $\begin{array}{l}\text { Frequency of } \\
\text { detections } \\
\text { exceeding } \\
\text { backgraund }\end{array}$ & $\begin{array}{c}\text { Maximmam } \\
\text { RL }\end{array}$ & $\begin{array}{c}\text { Frequescy } \\
\text { of detects } \\
\text { exceding } \\
\text { moximum } \\
\text { RL } \\
\end{array}$ & $\begin{array}{c}\text { Averase } \\
\text { Zone I } \\
\text { remediation } \\
\text { level } \\
\text { (pCys) }\end{array}$ & $\begin{array}{c}\text { Erceed } \\
\text { Zone I } \\
\text { querage } \\
\text { remedikties } \\
\text { level? } \\
\end{array}$ & 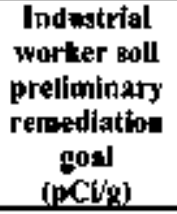 & $\begin{array}{l}\text { Frequency } \\
\text { of dettects } \\
\text { exceedlug } \\
\text { prebininary } \\
\text { remedistion } \\
\text { zokal }\end{array}$ \\
\hline Americium-24l & 09 & ND & ND & ND & $\mathrm{NA}$ & $9 / 9$ & NA & $\mathrm{NA}$ & $\mathbf{N A}$ & $N A$ & $5.705+01$ & $0 / 9$ \\
\hline Cesium-137 & 84 & 0.016 & 3.14 & 1.07 & I & $3 / 9$ & 20 & o/g & 2 & No & $1.12 \Gamma+00$ & 29 \\
\hline Coball-60 & $1 / 9$ & 0.0159 & 0.0159 & 0.02 & $\mathbf{N A}$ & $1 / 9$ & $\mathrm{NA}$ & $\mathrm{NA}$ & NA & NA & $5.96 \mathrm{E}-0]$ & 0 \\
\hline Neptımum-237 & 0 & ND & $\mathrm{ND}$ & ND & NA & $0 / 9$ & 50 & פינס & 5 & No & $2.70 \mathrm{E}+00$ & $0 / 9$ \\
\hline Plutonimn-238 & $0 / 9$ & ND & ND & ND & NA & $0 / 9$ & NA & NA & NA & NA & $1.66 \mathrm{E} \cdot \mathrm{N02}$ & 09 \\
\hline Piutonım-239 & 19 & $0.17 \mathrm{~J}$ & $0.17 \mathrm{~J}$ & 0.17 & NA & 19 & $N A$ & NA & NA & NA & $145 E+02$ & 09 \\
\hline Radium-226t & $8 / 8$ & 0.362 & 1.46 & 0.65 & 1.25 & $1 / 8$ & 15 & $0 \times 8$ & 5 & No & $2.55 E-01$ & $8 B^{\circ}$ \\
\hline Radıum-228 & 90 & 0.21 & 1.28 & 0.67 & 1.86 & $0 / 9$ & NA & NA & NA & NA & $1.58 \mathrm{E}-02$ & $9 / 9^{\prime \prime}$ \\
\hline Stronlium-90 & $0 / 8$ & ND & No & $\mathrm{ND}$ & NA & 0 of & NA & NA & NA & NA & 1.07E-1.02 & $0 / 8$ \\
\hline Techtreuum-99 & $0 / 9$ & ND & ND & $\mathrm{ND}$ & NA & 0 & $\mathbf{N}_{\mathrm{A}}$ & NA & $\mathrm{NA}$ & $N A$ & 8.94E-103 & $0 / 9$ \\
\hline Thoriun-228 & 99 & 0.268 & $1.37 \mathrm{~J}$ & 0.73 & 1.86 & ons & NA & $\mathrm{NA}$ & NA & $\mathrm{NA}$ & $1.58 \mathrm{E}-02$ & $9 \times 9^{b}$ \\
\hline Thorium-230 & $9 / 9$ & $0.496 \mathrm{~J}$ & $2.14 \mathrm{~J}$ & 0.97 & 1.2 & 19 & NA & $\mathrm{NA}$ & NA & NA & $2.11 E+02$ & $0 / 9$ \\
\hline Thor|um-232 & $9 / 9$ & 0.309 & $1.5 \mathrm{~J}$ & 0.73 & 1,95 & $0 / 9$ & 15 & $0 / 9$ & 5 & No & $1.58 \mathrm{E}-02$ & $9 / 9^{b}$ \\
\hline Urannum-234 & $9 / 9$ & 0.303 & $1.7 \mathrm{~J}$ & 0.9 & 1.47 & $2 M$ & 7000 & arg & 700 & No & $3.34 \mathrm{E}+02$ & 009 \\
\hline Uranium-235 & $3 / 8$ & $0.0885 \mathrm{~J}$ & $0.265 \mathrm{~J}$ & 0.15 & NA & $3 / \beta$ & 80 & $0 / 8$ & 8 & No & $3.94 \mathrm{E}+00$ & $0 / 8$ \\
\hline Uranıum-238 & $9 / 9$ & 0.32 & $1.56 \mathrm{~J}$ & 0.84 & 1.47 & 19 & 500 & $\theta / 9$ & 50 & No & $1.79 \mathrm{E}+0 \mathrm{]}$ & $0 / 9$ \\
\hline
\end{tabular}

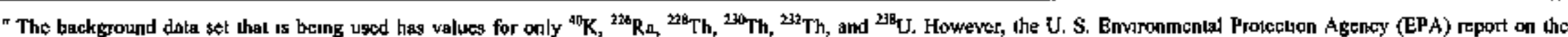
Seplember 2001 sampling of the Scartorr communily (SESD Project No. 01-1222, Aprl 2003) detnoles thal, in some cases, the PRG values are far below ithe background values. As an

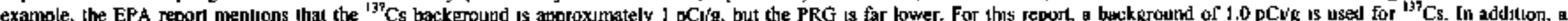

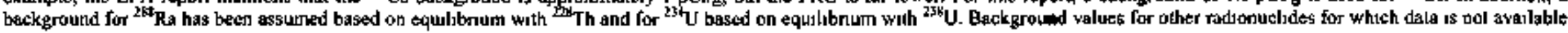
Ire assumed to be zero.

"PRG not applicable for this jadiousclide, due to an exception in the Zone I Record of Decisson. The exceplion takes backeround levels for these radionuclides into consideration.

'Assumed to be in equilibnum with measured radon progeny, ${ }^{214} \mathrm{~B}_{1}$.

"Assumed to be in equilibrium with measured progeny. Ac.

NA $=$ Not applicable, not available or insufficiest datis to cilculare the staitsulc.

ND $=$ Nod detectiod

$\mathrm{pCu} \mathbf{g}=$ pucocunes perT gram,

RL = jemedjutron level. 


\section{REFERENCES}

BJC (Bechtel Jacobs Company LLC) 1996. Radiation Protection Program, BJC-SH-04, Vol. 1, Sect. SHB-4012, "Radiation Contamination Control and Monitoring," Oak Ridge, TN.

BJC 1999. Isotopic Distribution of Contamination Found at the U. S. Department of Energy Gaseous Diffusion Plants, BJC/OR-407, Oak Ridge, TN, October.

BJC 2006a. Design of Radiological Survey and Sampling to Support Title Transfer or Lease of Property on the Deparment of Energy Oak Ridge Reservation, BJC/OR-554-R I, Oak Ridge, TN, August.

BJC 2006b. Exposure Unit Z2-02, Technicol Memorandum, Oak Ridge, TN.

CFR (Code of Federat Regulations) 1999. Occupational Radiation Protection, 10 CFR 835, Appendix D, "Surface Radíoactivity Values."

COE (U. S. Army Corps of Enginers) 1998. Personal communication with Bill Barnes of the U. S. Anny Corps of Engineers on April 6, 1998.

DOE (U. S. Department of Energy) 1993. Radiation Protection of the Public and the Environment, DOE Onder 5400.5, Fig. [V-1, "Surface Contamination Guidelines."

DOE 1997. Engineering Evaluation/Cost Anatysis for Equipment Removal and Building Decontamination for Butldings $K-29, K-31$, and $K-33$, East Tennessee Technology Park, Oak Ridge. Tennessee, DOE/OR/02-1579/D2, Jacobs Engineering, Oak Ridge, TN.

DOE 1998a. Final Report on the Background Soil Characterization Project at the Oak Ridge Reservation. Oak Ridge, Tennessee, DOE/OR-01-1175/V2, Uf, S. Department of Energy, Oak Ridge, TN.

DOE 1998b. Record of Decision for Interim Actions in Zone I, East Tennessee Technology Park. Oah Ridge, Tennessee, DOE/OR-01-1997\&D2, U. S. Department of Energy. Oak Ridge, TN.

DOE 2002. Record of Decision for Interim Actions in Zone 1 of East Tennessee Technology Park. Oath Ridge, Tennessee, DOE/OR/01-1997\&D2, U. S. Department of Energy, Office of Environmental Management, Oak Ridge, TN, October.

DOE 2005. Remedial Action Work Plan for Dynamic Verification Strategy, East Tennessee Technology Park, Oak Ridge, Tennessee, DOEJOR-01-2182\&D2, U.S. Department of Energy, Office of Environmental Management, Oak Ridge, TN, Febnary.

DOE 2006a. Proposed Real Estate Action, Oak Ridge Reservation, Oak Ridge, TN, September 12.

DOE 2006b. Removal Action Report for Equipment Removal and Building Decontamination for Bulldings K-29, K-3I, and K-33, East Tennessee Technology Part, Oak Ridge, Tennessee, DOE/OR-012290\&D1, U.S. Department of Energy, Office of Environmental Management, Oak Ridge. TN.

Energy Systems (Lockheed Martin Energy Systems, Inc.) 1995. Sife Descriptions of Environmental Restoration Units at the Oak Ridge K-25 Site, Oat Ridge, Tennessee, K/ER-47/R1, Oak Ridge, TN, September 1995. 
Energy Systems (Lockheed Martin Energy Systems, Inc.) 1997. Oak Ridge East Tennessee Technology Park Undergnound Storage Tank Management Plan, K/EM-549, Oak Ridge, TN, September 1997.

EPA (U. S. Environmental Protection Agency) 1994. National Functional Guidelines for Organic Data Review, EPA 540/R-94/012, Washington, D.C., Febriary 1994.

EPA 1999. National Functional Guidelines for Organic Data Review, EPA-5401R-99-008, Washington, D.C.

EPA 2014. National Functional Guidelines for Inorganic Data Review, EPA 540-R-04-004, Washington, D.C.

LMES (Lockheed Martin Energy Systems, Inc.) 1997. Sanitized Version of Building List, September 1946 through November $196 I$ [This report contains lists from the Years 1946, 1948, 1950 through 1958, 1960, and 1961\}, K/CR-749, East Temressee Tectnology Park, Oak Ridge, TN, December.

MMES (Mertin Marietta Energy Systems, Inc.) 1991a. Letter, C. C. Watson, K-25 Safery Analysis Review Group, to J.S. Dalton, Division Manager, Power and Utilities, "Approved Preliminary Hazard Screening Document for K-793-A-D, K-795-A-D, K-733-A, K-763-B-C, K-601," September 9.

MMES 1991b. Letter, C. C. Watson, K-25 Safety Aualysis Review Group, to J. S. Dalton, Division Manager, Power and Utilities, "Approved Preliminary Hazard Screening Document for K-792," August 23.

MMES 1993. Health Physics Techrician Training Handouts.

NRC (Nuclcar Regulatory Comirission) 2000. Multi-Agency Radiation Survey and Site Investigation Momal, Final Edition, NUREG-1575, Rev, 1, Rockville, MD, $664 \mathrm{pp}$.

Stanley, Milton A. (comp.) 1999. Oak Ridge Gaseots Diffusion Plant Building Lists Since /961, HIPS-99301, Historical lnvestigations and Publishing Services, Oak Ridge, TN.

TVA (Tennessee Valley Authority) 1998. Personal communication with Jirnny Massengill of the Tennessee Valley Authority on Apnil 6, 1998. 
APPENDIX A

STUDY AREA MAPS FROM RECORDS SEARCH 


\section{PROPOSED REAL ESTATE ACTION, OAK RIDGE RESERVATION, TN FILES RESEARCH FOR HAZARDOUS SUBSTANCE ACTIVITY}

The following stritemept is provided in support of guidase promulgated under Section 120(h) of the Comprehensive Envirommental Response, Comptensation and Libbility Act, as amended (CERCLA) 42 U.S.C. 9620(h) and is support of regulations issued by the Environmental Protection Agency at 40 CFR Part 373.

The undersigned has made a complete search of existing and available Despartment of Energy (DOE) records, documentation, and dsta within the real estate files relating to the property that is subject to the proposcd lease action of Parcel K-1251 (Barge Facility) at the East Tentessee Technology Park (ETTP) within the Oak Ridge Reservation, Temessee. The proposed antion would result in a lease to the Heritage Center, L.LC. The search conducted was considered reasonable with a good faith effort expended to identify whether any hazardous substances were known to have been released or disposed of on the property. The avatiable real estate records of this office do not reflect any deferminable reference that bazardous substance activity as defined by Section 101(14) of CERCLA took place on or in the property during the tirne the property wes owned by the United States of America.

Lands affected by this action spe joientified as portions of the following original acquisition tracts in which the United States of America acquired titte, (having been acquired for the Atomic Energy Coranission as a forermner of the Department of Energy) by Civil Action No. 429 filed in the United States District Court for the Eastem District of Tennessee, Northem Division:

Parcel K-125l is tocated on a portion of Tract H-738. Tit? to this land was vested in the United States of Americe by Deelaration of Taking No. 19. Judgenent on Declaration of Taking was filed for public record on February 23, 1943, in Vol. Y-5, Page 139, in the Roane County Register's Offioe, Tennessee.

Parcel K-125] is located on a portion of Tract B, acquired from the Department of Ammy under a Use Permolt, Executtve Order Nanher 9816.

This record shall be made a part of the CERCLA repont curontly being prepared.

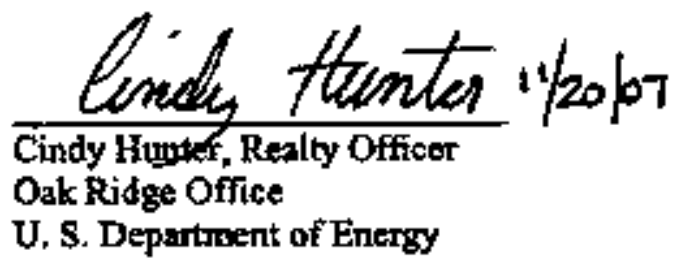

Attachment

Acquisition Tract Map 


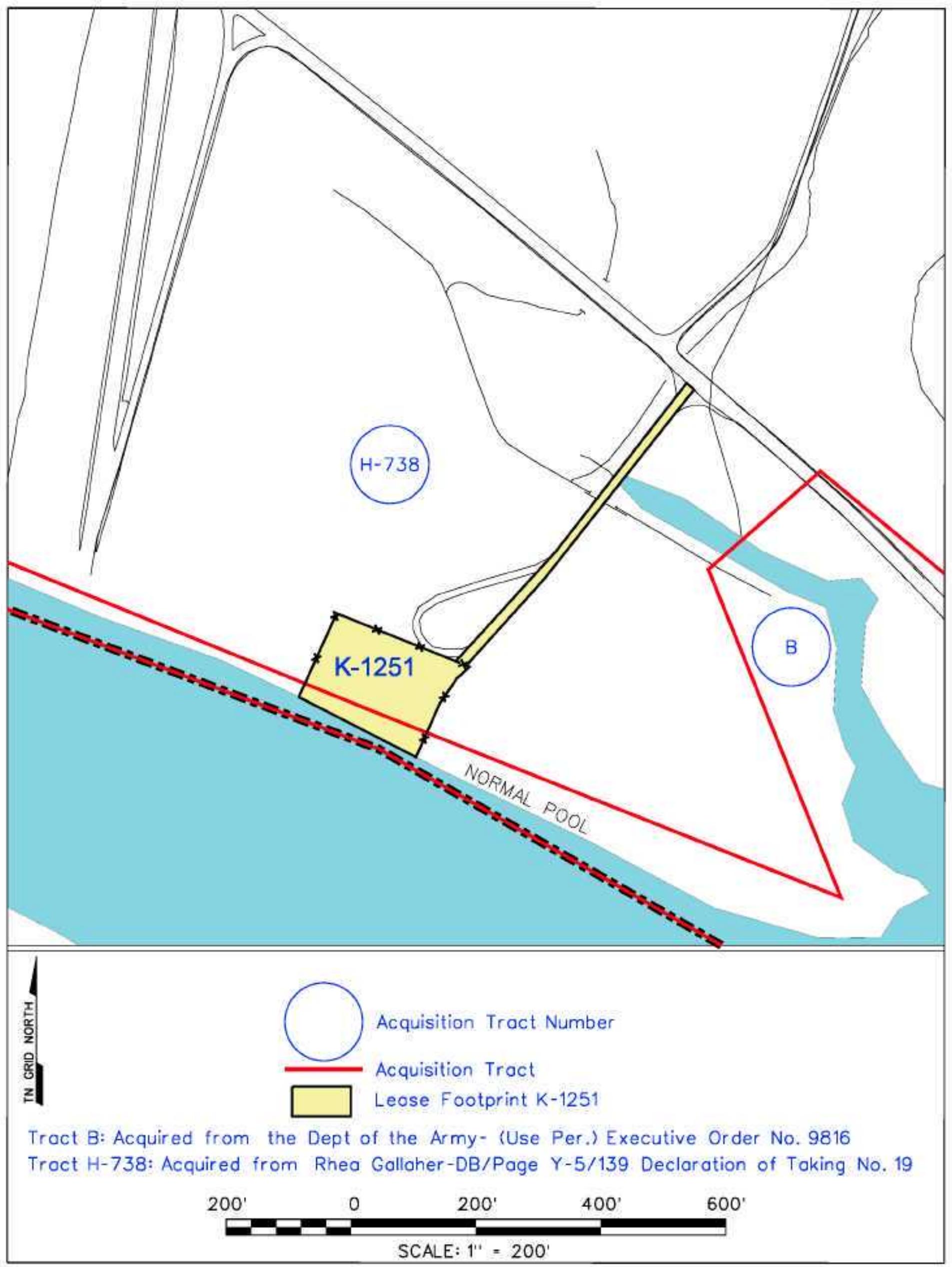




\section{APPENDIX B}

SAMPLING AND ANALYSIS PLAN FOR THE K-1251 BARGE FACILITY 


\section{Sampling and Analysis Plan for the K-1251 Barge Facility at the East Tennessee Technology Park, Oak Ridge, Tennessee}

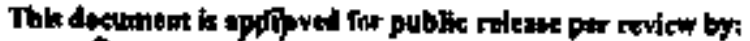

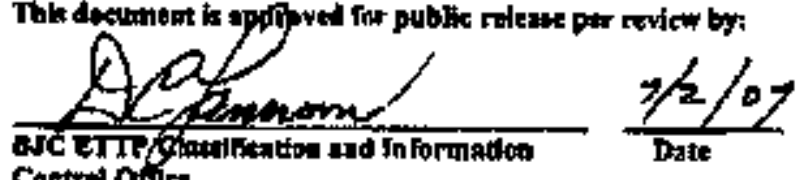


SCIENCE APPLICATIONS INTERNATIONAL CORPORATION

contributed to the preparation of this document and should not be considered an eligible contractor for its review. 


\title{
Sampling and Analysis Plan for the $\mathrm{K}$-1251 Barge Facility at the East Tennessee Technology Park, Oak Ridge, Tennessee
}

Date Issued-July 2007

\author{
Prepared by \\ Science Applications intemationel Corporation \\ Oak Ridge, Tennessee \\ under subcontract 23900-BA-PR007U \\ under work reltase 000700
}

\author{
Prepared for the \\ U. S. Departmenl of Energy \\ Office of Nuclear Fuel Supply \\ BECHTEL JACOBS COMPANY LLC \\ managing the \\ Environmental Management Activities at the \\ East Tennessee Technology Park \\ Y-12 National Security Complex Oak Ridge National Laboratory \\ under contract DE-AC05-98OR22700 \\ for the \\ U. S. DEPARTMENT OF ENERGY
}




\section{CONTENTS}

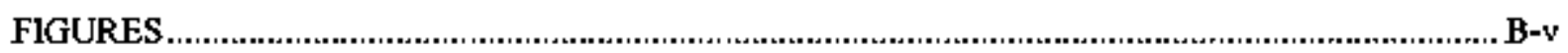

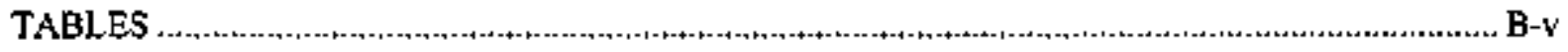

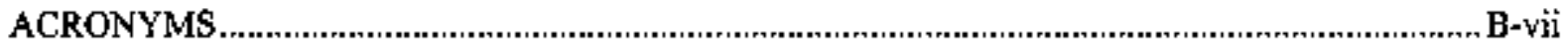

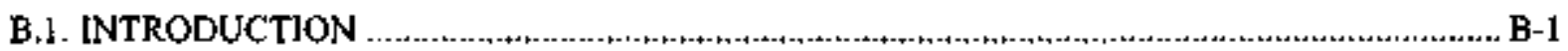

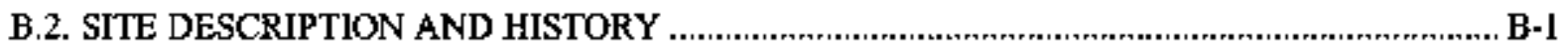

B.2.1 OPERATIONS CONDUCTED AT THE FORMER K-1251 BARGE FACILITY ..................

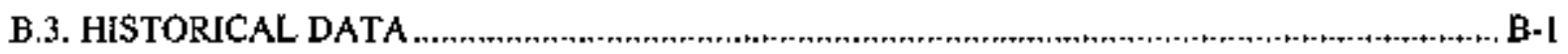

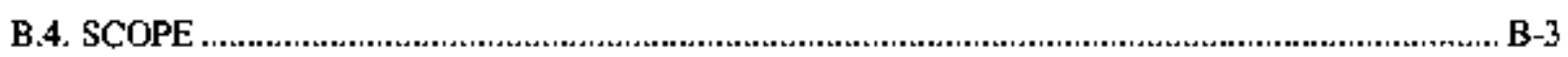

B.5. SOLL SAMPLING RATIONALE AND DESIGN ..................................................................... B-3

B.5.1 SAMPLING OBJECTIVES FOR THE SOIL AND CONCRETE PAD ............................... B-3

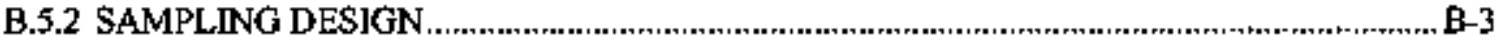

B.5.2.1 Sampling Design for Collection of Soil Samples .................................................... B-3

B.5.2.2 Sampling Design for Collection of Concrete Pad Samples ..................................... B-5

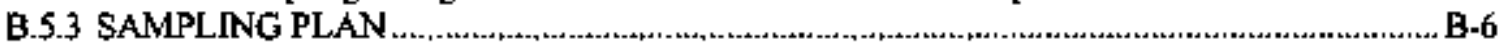

B.5 3.] Soil Sampling Plan................................................................................................ B-6

B.5.3.2 Concrete Pad Sampling Plas .................................................................................... B-6

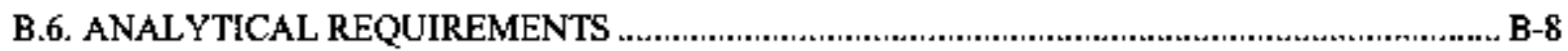

B.7. DATA MANAGEMENT AND REPORTING

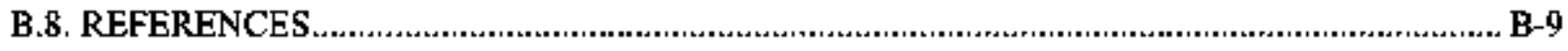

APPENDLX A ADDENDUM TO THE BAS]C ORDERING AGREEMENT ATTACHMENT 1

STATEMENT OF WORK MINIMUM REQUIREMENTS FOR RADIOCHEMISTRY

FOR BECHTEL JACOBS COMPANY, LLC REINDUSTRLALIZATION PROJECT $A=1$ 


\section{FIGURES}

B.2.1 K-1251 Barge Facility loction map. ........................................................................... B

B.5.] Biased sampling locations at the K-1251 Barge Facility ......................................................... B-4

\section{TABLES}

B.5.1 Summary of analyses for surface and subsurface soil samples in the $K_{-}-1251$ footprint .............. B-5

B.5.2 Summary of analyses for concrete pad samples at K-1251 .................................................... B-5

B.5.3 Container, preservation, and bolding time requirements for the $\mathrm{K}-1251$ samples ....................... B- 7

B.6.1 Analytical requirements for the K-1251 soil samples ............................................................. B-8

B.6.2 Potential target radionuclides and reporting requirements ........................................................9.9 


\section{ACRONYMS}

$\begin{array}{ll}\text { bgs } & \text { below ground surface } \\ \text { DCGL } & \text { derived concentration guideline levei } \\ \text { MDL } & \text { method detection limil } \\ \text { NaI } & \text { sodium ioditte } \\ \text { PCB } & \text { polychlorinated biphenyl } \\ \text { PID } & \text { photoionization detector } \\ \text { SAP } & \text { Sampling and Analysis Plar } \\ \text { SOP } & \text { standard operating procedure } \\ \text { SSC } & \text { sampling subcontractor } \\ \text { SVOC } & \text { semivolatite organic compound } \\ \mathrm{UF}_{6} & \text { uranium bexafluoride } \\ \mathrm{UO}_{2} \mathrm{~F}_{2} & \text { uranyl difluoride } \\ \text { VOA } & \text { volatile organic analysis (or analyte) } \\ \text { VOC } & \text { volatile organic compound }\end{array}$




\section{B.1. INTRODUCTION}

This Sampling and Analysis Plan (SAP) describes the sampling activities to assess the potential for chemical or radiological contamination within soils in the vicinity of the K-1251 Barge Facility at the East Tennessee Technology Park, Oak Ridge, Tennessee. Additionally, this SAP deseribes sampling activities to determine if polychlorinated biphenyl (PCB) contanination is present upon the former crane pad in the subject area. The constituents selected for analysis are those compounds identified in Chap. B.5 of this plan.

\section{B.2. SITE DESCRIPTION AND HISTORY}

\section{B.2.1 OPERATIONS CONDUCTED AT THE FORMER K-12SI BARGE FACILITY}

The K-1251 barge unloading facility began operations in 1953. The facility was removed from operation in the early 1990s and the equipment removed in 1995. It is located along the Clinch River and an inlet of the river, which forms its southern boumdary. It is bounded to the north. by Highway 58. As depicted in Fig. B.2.1, the footprint for the subject area is defined by security fencing that sunounds a concrete pad and a gravel-covered area.

The K- 1251 barge unloading facility was used to transfer uranium bexafluoride (UF $\mathrm{U}_{6}$ ) cylinders. The $\mathrm{K}-[25]$ facility is currently inactive and all equipment, including a large crane, has been removed. Although UF sylinders were transferred at this facility, historical information does not indicate that any releases occurred. In addition to potential radionuclide contamination that may have resulted from releases from the $\mathrm{UF}_{6}$ cylinders, historical releases of hydraulic fluids, lubricating oils, or fuels from operation and maintenance of the crane may have contributed volatile organic compounds (VOCs). semivolatile organic compounds (SVOCs), and PCBs.

\section{B.3. HISTORICAL DATA}

Only one historical sample is available from the K-125l footprint. The activities of all detected radionuclides were below their respective background values. No radionuclides were detected with activities that exceeded their respective derived concentration guideline levels (DCGLs). 


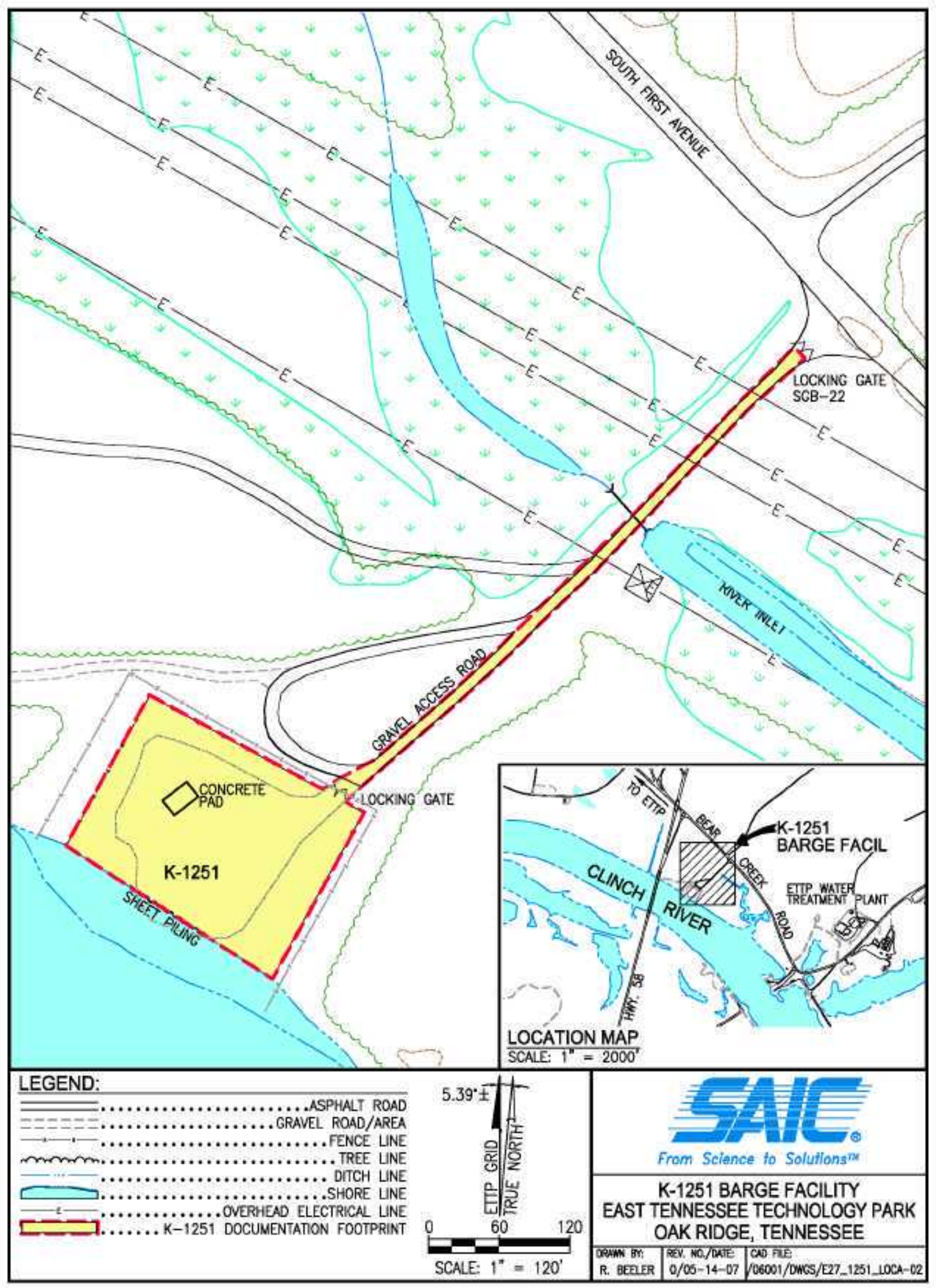

Fig. B.2.1. K-1251 Barge Facility location map. 


\section{B.4. SCOPE}

The overali scope of this SAP is to determine: (1) the potential for contamination (radiological and chennical) within soils located inside the footprint area, and (2) whether PCB contamination is present upon the conctete pad (formerly used with the crane operation) in the footprint area. The first overall objective will be met by sampling the soils within the footprint at near surface [ 0 to $0.5 \mathrm{ft}$ below ground surface (bgs)] and at depth ( 0.5 to $2.0 \mathrm{ft}$ bgs and $2.0 \mathrm{ft}$ to $10 \mathrm{ft}$ bgs or to the top of the water table). The second objective will be achieved by collection of concrele coring samples from the crane pad in the footprint. Specific sampling locations and rationale are discussed within Chap. B.5 of this SAP.

\section{B.5. SOIL SAMPLING RATIONALE AND DESIGN}

\section{B.5.1 SAMPLING OBJECTIVES FOR THE SOIL AND CONCRETE PAD}

In order to facilitate lease of the property, it is necessary to demonstrate that contamination from past activities bas not occurred or is not present within the footprint of the property at levels thal would constitute a risk due to potential exposures. Based on the history of site operations, only a limited number of samples near the concrete crane pad are necessary to demonstrate that contamination is not present in soils in the footprint. Only a limited number of samples from the pad itself are needed to demonstrale the absence of PCB contamination on this structure. Therefore, the sampling design is judgmental in nature.

\section{B.5.2 SAMPLING DESIGN}

\section{B.5.2.1 Sampling Design for Collection of Soil Samples}

The history of the $\mathrm{K}-125 \mathrm{l}$ barge facility indicates that the area was used for transfer of $\mathrm{UF}_{6}$ cylinders for or from barge transport. No releases of $\mathrm{UF}_{8}$ during operations have been documented. However, any release that may have occurred during operations would tot transport any significanl dislance because the $\mathrm{UF}_{6}$ would have immediately hydrolyzed to uranyl difluoride $\left(\mathrm{UO}_{2} \mathrm{~F}_{2}\right)$ upon contact with air. The resultant $\mathrm{UO}_{2} \mathrm{~F}_{3}$ particles would have precipitated rapidly from the gas phase, and deposition would tend to be localized. Any chenical contamination in the area is expected to bave resulted from releases of fuel or hydraulic fluids incidental to operation of the crane and would be localized in its vicinity. Therefore, if any chemical or radiological contamination is present, it is likely to be localized near the crane pad. Three sampling locations indicated in Fig. B.5.1 were selected on a judgmental basis.

All sampies taken from these locations will be analyzed for radioactive and chemical contamination. Soil samples will be collected near surface $(0.0$ to $0.5 \mathrm{ft} \mathrm{bgs)}$ and at depth $(0.5 \mathrm{ft}$ to $2.0 \mathrm{ft}$ bgs and 2.0 to $10.0 \mathrm{ft}$ bgs or to the top of the water table). This information is presented in Table B.5.1. 


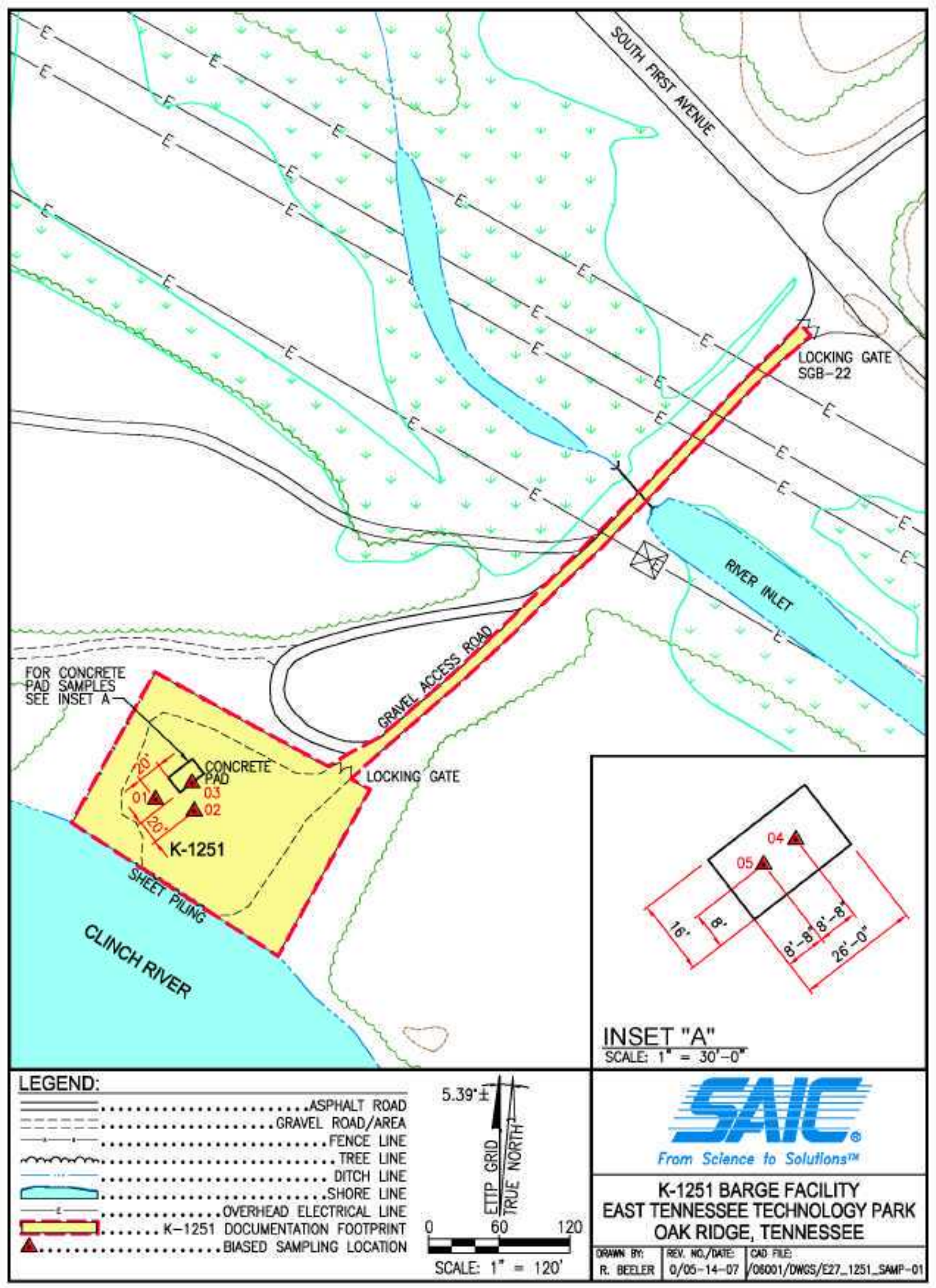

Fig. B.5.1. Biased sampling locations at the K-1251 Barge Facility. 
Tabie B.5.1. Summary of analyges for surface and subsurface soil samples in the K-1251 footprint

\begin{tabular}{|c|c|c|c|c|c|c|c|c|}
\hline Semple number & Sample depth & Metals ${ }^{a}$ & vocs ${ }^{b}$ & SVOCB" & PCAS & $\begin{array}{c}\text { Baseline } \\
\text { redtanusildes }\end{array}$ & $\begin{array}{c}\text { Total } \\
\text { ectulty }\end{array}$ & $\begin{array}{c}\text { TRU } \\
\text { isatopes' }\end{array}$ \\
\hline NS-01-01-12S1 & $00-05$ & $\mathrm{x}$ & $X^{2}$ & $\mathrm{x}$ & $\bar{x}$ & $x$ & $\bar{x}$ & $\mathrm{x}$ \\
\hline NS- $-01-02-125]$ & $0 \leqslant-2,0$ & $x$ & $x^{2}$ & $\mathrm{x}$ & $\mathrm{x}$ & $\mathrm{x}$ & $x$ & $x$ \\
\hline NS- $-01-03-125]$ & $2.0-100$ & $\mathrm{x}$ & $X^{2}$ & $x$ & $x$ & $\mathrm{x}$ & $x$ & $x$ \\
\hline NS- $-02-01-1251$ & $00-05$ & $x$ & $x^{*}$ & $x$ & $x$ & $\mathrm{x}$ & $x$ & $x$ \\
\hline NS- $-02-02-1251$ & $05-20$ & $x$ & $X^{r}$ & $\mathrm{x}$ & $x$ & $\mathrm{x}$ & $\mathrm{x}$ & $\mathrm{x}$ \\
\hline NS-03-01-125] & $00-05$ & $\mathrm{x}$ & $x^{\mathrm{l}}$ & $\mathrm{x}$ & $\mathrm{x}$ & $x$ & $x$ & $x$ \\
\hline NS- $03-02-125]$ & $05-20$ & $x$ & $x^{r}$ & $x$ & $\mathrm{x}$ & $x$ & $x$ & $x$ \\
\hline NS- $03-03-125]$ & $2,0-10.0$ & $\mathrm{x}$ & $x^{r}$ & $\mathrm{x}$ & $\mathrm{x}$ & $x$ & $x$ & $x$ \\
\hline NS-ER-81-1000 & $\mathrm{NA}_{\mathrm{A}}$ & $\mathrm{x}$ & $x$ & $\mathrm{x}$ & $\mathrm{x}$ & $x$ & $\mathrm{x}$ & $x$ \\
\hline NS-TB-01-1000' & $\mathrm{NA}_{\mathrm{A}}$ & & $x$ & & & & & \\
\hline NS-FB-01-1000 & $\mathrm{NA}$ & & $x$ & & & & & \\
\hline
\end{tabular}

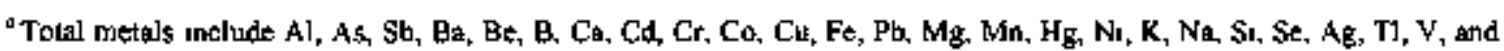
2ᄁ.

"Target Compound List (TCL)-VOCs and TCL-SVOCs are to be quantulied

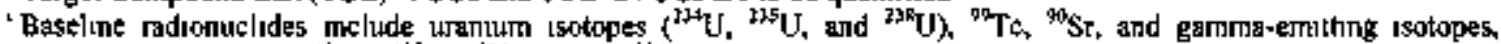

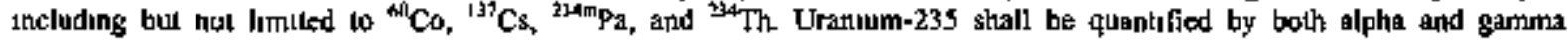
spcetroscopy

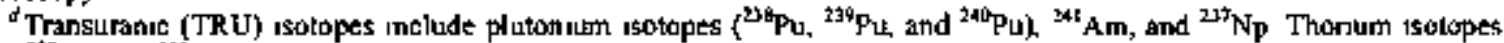
$\left({ }^{221} \mathrm{Th}_{1}{ }^{250} \mathrm{Th}\right.$, and ${ }^{2 \times 2}$ Th) shakl also be quantified in these samples.

'YOC sarmple shall be an aliquot collected proor to compositung remaning sample materal. For the 0.5- to 2 0- $n$ and 20. to 100 -ft interualis, the aliquot shall be collected from the portion of the corolg with the most elevated photoionization detector (PID) ręadiłn:

'Samples designaied NS-ER, NS-TB, and NS-FB are equnpment nnsates, tnp blanks, and field blanks, respectıvely

NA = rol applicable

PCB = polychloringted bipheny $\mathrm{l}$.

SVOC - semivolatıle organue compound.

$V O C=$ volatıle organic compound.

\section{B.5.2.2 Sampling Design for Collection of Concrete Pad Samples}

Any chemical contamination remaining on the pad likely resulted from releases of fuel or bydraulic fluids incidental to operation of the crane. Visual inspection of the pad on May 7, 2007, did not indicate any residual staining and, therefore, the two sampling locations indicated in the inset $10 \mathrm{Fig}$. B.5.1 were selected to be equidistant from the edge of the pad. The sample identification numbers for these samples are provided in Table B.5.2.

Table B.5.2. Summary of anglyses for concrete pad saniples at K-1251

\begin{tabular}{ccc}
\hline & $\begin{array}{c}\text { Sample deptl } \\
\text { (Ln.) }\end{array}$ & PCBs \\
\hline NS-04-01-125] & $0-2.5$ & $X$ \\
NS-05-01-1251 & $0-2.5$ & $X$ \\
\hline
\end{tabular}

PCB - polychlonnated biphenyl. 


\section{B.5.3 SAMPLING PLAN}

\section{B.5.3.1 Soil Sampling Plan}

Surface and sub-surface soil samples shall be collected in accordance with the sampling subcontractor's (SSC's) contract specifications, "Exhibit E, Standard Specifications for Environmental Sampling." The following description of the field sampling methods is provided as a general synopsis and does not supercede the contract requirements.

Surface soil samples collected at each of the locations specified in Fig. B.5.I shall be manually collected using either a shovel or hand-held auger to obtain a soil sample from the $0.0-$ to $0.5-\mathrm{ft}$ below ground surface (bgs) interval. Near-surface soil samples (0.5- to 2.0-ft bgs) collected at each of the locations specified in Fig. B.5.1 may be collected using either a hand-beld auger or through the use of direct-push techniques (DPT) such as a Geoprobe(b' drilling rig. Subsurface soil samples (2.0- to 10 -ft bgs) will be collected al the specified locations using DPT (e.g., Geoprobe(8) to advance 1.5-in. outside dianterter (OD) probe rods with a solid, 1.125-in.-diameter drive point from 2.0 to $10 \mathrm{ft}$ bgs. A 48 -in.-long, 2.125 -in.-OD sampler with acetate liner will be used to collect the soil core from the designated sarnpling depths.

VOC samples shall be collected as discrete samples from within the designated sample intervals. Following collection of a discrete sample for VOC analysis from the surface soil sample, the remaining soil material for metal, SVOC. PCB, and radionuclide analyses shall be obtained by transferring the collected sarface soil material to a stainless steel mixing bowl and homogenizing the material for placement in the sample containers indicated in Table B.5.3. Upon opening the sample liner used for collection of the subsurface soil samples, and near-surface, if applicable, the soil core shall be scanned using a photoionization detector (PID) and a sodium iodide (NaI) detector. Samples for VOC analysis stall be collected from the portion of the sample that exhibits elevated PID readings from the center of the sample core. If no portion of the sample exhibits an elevated reading, the VOC sample shall be selected tandornly from the collected material at the center of the sample core. Samples for VOC analyses may be obtained using Eacore $\left(\theta^{2}\right.$ samplers or Method $8260 \mathrm{~B}$ sampling tubes. Samples for SVOC analysis shall also be obtained from the portion of the soil core that exhibits elevated PID readings, if applicable.

Samples for both metals and radionuclides shall be collected from the portion of the soil core that exhibiled the most elevated Nal reactings upon retrieval of the soil core. If no portion of the core exhibited elevated PID or NaI readings, the sample material for SVOC, PCB, radionuclide, and metal analyses shall be obtained by transferring the soil core from the designated sample interval to a stainless steel mixing bowl and homogenizing the material for placement in the sample containers indicated in Table B.5.3. Sarnple containers shall be managed as indicated above and in accordance with the SSC's SOPs. Sampling equipment shall be decontaminated between stations in accordance with the SSC's SOPs.

\section{Bs.3.2 Concrete Pad Sampling Plan}

Samples from the concrete pad shall be collected at each of the locations specified in the inset to Fig. B.5. J. Core samples of the concrete pad shall be collected using a pre-cleaned, band-held, powwer-driven oprer with a 2.0-in.-diameter coring bil that is driven into the floor to a depth of $n 2.5 \mathrm{in}$. Onde the coring bit has reached the specified depth, the bit shall be vibrated to break the concrete sample loose from the slab. The material will be crushed at the labonatory for extraction and analysis. Upon collection of each sample, it shall be transfirred to the sample containers indicated in Table B.5.3. Upon filling each container, it sball be sealed, wiped clean, and the lid secured in accotdance with the SSC's SOPs. Sampling oquipment shall be decontaminated between stations as required by the SSC's SOPs.

\footnotetext{
'Reference heren to any specific exmenercial product, process, or seryce by Irade пarne, trademank, manufacturer, or otherwise, does noi necessanly constifule or imply its endorsement, recommendatıot, or favoring by the United States Gowemment or any agency thereof of its contractors or subcontractors.

$=$ lbid.
} 
Table B.5.3. Container, preservation, and boldigg time requirenents for the K-1251 samples

\begin{tabular}{|c|c|c|c|c|}
\hline Sample locotian & Parameters of concern & Container type/volume & Preservation & $\begin{array}{c}\text { Holding } \\
\text { time }\end{array}$ \\
\hline Localrons 01,02 , and 03 & $\begin{array}{l}\text { Total melals }{ }^{a} \\
\text { Mercury }\end{array}$ & $\begin{array}{l}\text { 8-0z glass - Teflon } \\
\text { Taken from above }\end{array}$ & $\begin{array}{l}\text { Cool } 4^{\circ} \mathrm{C} \\
\text { Cool } 4^{\circ} \mathrm{C}\end{array}$ & $\begin{array}{l}180 \text { days }^{2} \\
28 \text { days }^{\circ}\end{array}$ \\
\hline Locations 01,02 , and 03 & Total volatile organies $s^{b}$ & $\begin{array}{l}\text { Three pre-marked sample } \\
\text { tubes extruded to } 3-\times 40-\mathrm{mL} \\
\text { pre-preserved VOA viaIs or } 3 \\
\text { Encore(i) samplers }\end{array}$ & $\begin{array}{c}\text { One val Methanol - } \\
\text { Cool } 4^{\circ} \mathrm{C} \\
\text { One vial Methanol - } \\
\text { Cool } 4^{\circ} \mathrm{C} \\
\text { One val } \mathrm{NaHSO}_{3}- \\
\text { Cool } 4^{\circ} \mathrm{C}\end{array}$ & 14 days \\
\hline Locatons 01,02 , and 03 & $\begin{array}{l}\text { Total semivolatule } \\
\text { organics }\end{array}$ & $\begin{array}{l}\text { 8-0z A-glass - Teflon } \\
\text { closure }\end{array}$ & $\operatorname{Cool} 4^{\circ} \mathrm{C}$ & 14 days \\
\hline Locations 01,02 , and 03 & PCBs (Aroclors) & Taken from above & $\mathrm{Cool} 4^{\circ} \mathrm{C}$ & 14 days \\
\hline \multirow[t]{7}{*}{ Locations 01,02 , and 03} & Wranium isotopes & $\begin{array}{l}\text { I500-g glass - Teflon }{ }^{\mathrm{TM}} \\
\text { closwe }\end{array}$ & $\mathrm{Cool} 4^{\circ} \mathrm{C}$ & 180 days \\
\hline & ${ }^{239} \mathrm{U}$ & Taken from above & $\mathrm{Cool} 4^{\circ} \mathrm{C}$ & I 80 days \\
\hline & $\begin{array}{l}\text { Gamma-enitting } \\
\text { isotopes }\end{array}$ & Taken from above & $\mathrm{Cool} 4^{\circ} \mathrm{C}$ & 180 days \\
\hline & ${ }^{90} \mathrm{SI}_{\mathrm{I}}$ & Taken from above & $\mathrm{Cool} 4^{\circ} \mathrm{C}$ & 180 days \\
\hline & ${ }^{96} \mathrm{Te}$ & Taken from above & $\operatorname{Cool} 4^{\circ} \mathrm{C}$ & 180 days \\
\hline & Total alpha/bela achvity & Taken from above & $\mathrm{Cool} 4^{\circ} \mathrm{C}$ & 180 days \\
\hline & Total gamma activity & Taken from above & $\mathrm{Cool} 4^{\circ} \mathrm{C}$ & 180 days \\
\hline \multirow[t]{3}{*}{$\begin{array}{l}\text { Locations 01, 02, and } \\
03\end{array}$} & Pu Isotopes & $\begin{array}{l}\text { l500-g glass - Teflon }{ }^{\mathrm{TN}} \\
\text { closure }\end{array}$ & $\mathrm{Cool} 4^{\circ} \mathrm{C}$ & 180 days \\
\hline & ${ }^{241} \mathrm{Amm},{ }^{237} \mathrm{~Np}$ & Taken from above & $\operatorname{Cool} 4^{\circ} \mathrm{C}$ & 180 days \\
\hline & ${ }^{228} \mathrm{Th},{ }^{236} \mathrm{Th}$, and ${ }^{232} \mathrm{Th}$ & Taken from above & $\operatorname{Coot} 4^{\circ} \mathrm{C}$ & 180 days \\
\hline Locations 04 and 05 & PCBs (Aroclors) & $\begin{array}{l}\text { 8-oz A-glass - Teflon } \\
\text { clostre }\end{array}$ & $\operatorname{Cool} 4^{\circ} \mathrm{C}$ & $14 \mathrm{days}^{\mathrm{d}}$ \\
\hline \multirow[t]{8}{*}{ Equipinent tinsates } & Volattle organics & (3) $40-\mathrm{mL}$ VOA vials & $\mathrm{pH}<2, \operatorname{Cool} 104^{\circ} \mathrm{C}^{f}$ & 14 days \\
\hline & Seruivolatıle organics & (2) I-L A-glass - Teflon ${ }^{8} \mathrm{M}^{6}$ & $\operatorname{Cood} 4^{\circ} \mathrm{C}$ & 7 days $s^{2}$ \\
\hline & $\mathrm{PCBs}$ & Taken frous above & $\operatorname{Cool} 4^{\circ} \mathrm{C}$ & 7 days \\
\hline & Total metnis & 1-L Polybottle & $\mathrm{pH}<2$, Cool $4^{\circ} \mathrm{C}^{\mathrm{h}}$ & 180 days \\
\hline & Urannum Isotopes & (2) I-gal Polybottles & $\mathrm{pH}<2, \mathrm{Cool} 4^{\circ} \mathrm{C}^{t}$ & 180 days \\
\hline & 90 & Taken from above & $\mathrm{pH}<2$, Cool $4^{\circ} \mathrm{C}^{\mathrm{H}}$ & 180 days \\
\hline & $\mathrm{Sr}$ & laken trost above & $\mathrm{PH}<2, \mathrm{CDOl} 44^{\circ} \mathrm{C}$ & 580 days \\
\hline & Total acitvity & Taken from above & $\mathrm{pH}<2, \mathrm{CoOl} 4^{\circ} \mathrm{C}^{\prime r}$ & I 80 days \\
\hline Trup blenks & Volathle organies & (3) 40 -mL VOA vals & Pre-preserved & 14 days \\
\hline Freld blanks & Volate organics & (3) 40 -mL VOA vials & Pre-preserved & 14 days \\
\hline
\end{tabular}

"Total metals include Al, As, Sb, Ba, Be, B, Ca, Cd, Cr, Co, Cu, Fe, Pb, Mg, Mrt Hg, Nı, K, Na, Se, Si, Ag. T1, V, ard Zn Holdmig ume for mercury is 28 days

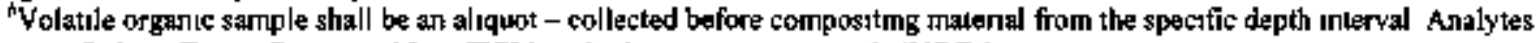
lo be quantJied are Target Compound List (TCL)-volatile organic conspounds (VOCs)

"Analy les lo be quantified are TCL-semı volatile organic compounds (SVOCs) A-glass - anber glass

"Holding hme is 14 days lo extrachon and 40 days from extracuon lo molystes

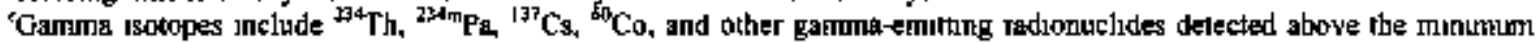
deteclable activity Urailum-235 shall be quanlitjed by bolh alpha and gamma spectroseopy

'Preservation requrtement for waler samples for volatile onganic compound analysis is addation of $\mathrm{HCl}$ to $\mathrm{pH}<2$ and cool $4^{\circ} \mathrm{C}$

* Holding time is 7 days lo extract won and 40 days from extraction to andalyses

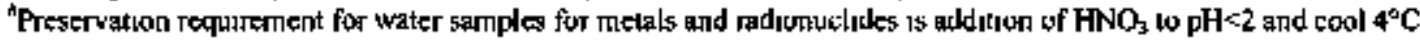

PCB = polychlonnated biphenyl

VOA - volatile organic analysis (or analyte) 


\section{B.6. ANALYTICAL REQUIREMENTS}

Analytical protocols for the analyte groups specified for the samples collected under this SAP are indicated in Table B.6.1. Samples for chemical analyses will be measured by the relevant SW-846 Methods (EPA 1993). Uranium isotopes will be analyzed by alpha spectroscopy except that ${ }^{235} \mathrm{U}$ will also be measured by gamma spectroscopy. Thorium isolopes will be analyzed by alpha spectroscopy; however, ${ }^{234}$ Th will be measured by gamma spectroscopy. Transuranic isolopes may be measured by alpha or gamma spectroscopy as appropriate. Scintillation counting will be used for quantitation of ${ }^{89} \mathrm{Sr}$, ${ }^{90} \mathrm{Sr}$ and ${ }^{0,5} \mathrm{Te}$.

Table B.6.1. Analytical requiremegts for the K-1251 soil sampies

\begin{tabular}{|c|c|}
\hline Parameters of concern & Analytical protoreole \\
\hline Tolal metals ${ }^{a}$ & $6010 \mathrm{~B}$ \\
\hline Mercury & 7471 \\
\hline Total volatile organics & $8260 B$ \\
\hline $\begin{array}{l}\text { Total semivivilatile } \\
\text { organics }\end{array}$ & $8270 \mathrm{C}$ \\
\hline PCBs (Atoclors) & 8082 \\
\hline${ }^{228} \mathrm{~Tb},{ }^{230} \mathrm{Th}$, and ${ }^{332} \mathrm{Th}$ & Alpha spectroscopy \\
\hline Uranium isotopes & Alpha spectroscopy \\
\hline${ }^{735} \mathrm{U}$ & Gamma spectroscopy \\
\hline Gamma-emitting isotopes & Gamma spectroscopy \\
\hline$\varphi_{T c}$ & Beta scintillation counting \\
\hline${ }^{90} \mathrm{Sr}$ & Beta scintillation counting \\
\hline Pụ Isotopes & Alpha spectroscopy \\
\hline${ }^{241} \mathrm{Am},{ }^{27} \mathrm{~Np}$ & Alpha spectroscopy \\
\hline Total alphabeta activity & Radiochemical counting method \\
\hline Total gamma activity & $\begin{array}{c}\text { Gamma scan mon-destructive, spectrum } \\
\text { method }\end{array}$ \\
\hline
\end{tabular}

- Total melals include Al, As, Sb, Ba, Be, B, Ca, Cd, Cr, Co, Cu, Fe, Pb, ME, Mr, $\mathrm{Hg}, \mathrm{Ni}, \mathrm{K} . \mathrm{Na}, \mathrm{Si}, \mathrm{Se}, \mathrm{Ag}, \mathrm{Tl}, \mathrm{V}$, and $\mathrm{ZH}$.

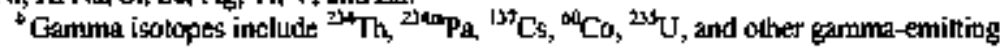
[adioruclides detected above the mínimum delextable activity.

RCB = polyctilorinated biphenyl.

Detection limits for chemical analytes of concern are those specified within the relevant SW-846 Method (EPA 1993). Minirnum detectable activities for the various radiomuclides that must be met by the analytical laboratory are specified in Table B.6.2. Additional analytical quality assurance/quality control and reporting requliements are provided in Appendix A. 
Tahle B.6.2. Potential target radionurlides and reporting requirements

\begin{tabular}{|c|c|c|c|}
\hline Anslysis & Method & $\begin{array}{c}\text { MDL } \\
\text { Water } \\
\text { (pCilL) }\end{array}$ & $\begin{array}{c}\text { MDL } \\
\text { Sorl, sludge, } \\
\text { floor } \\
\text { sweeplngs } \\
\text { (pCij/g) }\end{array}$ \\
\hline${ }^{3} \mathrm{H}$ & Radiochemical separation/liquid scintillation counting & 580 & 1100 \\
\hline${ }^{14} \mathrm{C}$ & Radichemical separationbeta count & 31 & 270 \\
\hline${ }^{50} \mathrm{Co}$ & Gamma spectrometry & 0.25 & 0.0045 \\
\hline Total & Radiochemical separalionfbeta count & 0.085 & 1.4 \\
\hline radioactive $\mathrm{Sr}$ & & & \\
\hline $\mathrm{Tc}$ & Radiochemical separationbela count & 3.4 & 57 \\
\hline${ }^{157} \mathrm{Cs}$ & Gamma spectrometry & 0.15 & 0.1 \\
\hline${ }^{208} \mathrm{Ac}$ & Gamma spectrometry & I & 1 \\
\hline${ }^{27} \mathrm{Th}$ & Radiochemical separation/alpha spectrometry & 0.021 & 0.1 \\
\hline${ }^{2+0} \mathrm{Th}$ & Radiochemical separation/alpha spectrometry & 0.13 & 0.1 \\
\hline${ }^{932} \mathrm{Th}$ & Radiochemical separation/alpha spectrometry & 0.25 & 0.1 \\
\hline${ }^{23 \mathrm{a}} \mathrm{Tb}$ & Gamma specttometry & i & 1 \\
\hline${ }^{2}+4 \mathrm{~m} \mathrm{~Pa}$ & Gamma spectrometry & 1 & 1 \\
\hline${ }^{24} \mathrm{U}$ & Radiochemical separation/alpha spectrometry or TI/MS & 0.11 & 0.1 \\
\hline${ }^{235} \mathrm{U}$ & Radiochemical separationdalphe spectrometry or TI/MS & 0.1 & 0.05 \\
\hline${ }^{2 \pi k} \mathrm{q}$ & Radiochemical separation/alpha spectronetry or TI/MS & 0.077 & 0.1 \\
\hline${ }^{237} \mathrm{~Np}$ & Radiochenical separation/alpha spectromerty & 0.016 & 0.091 \\
\hline${ }^{23.6} \mathrm{Pu}$ & Radiochemical separation/alpha spectrometry & 0.016 & 0.27 \\
\hline${ }^{239} \mathrm{Pu}$ & Radiochenical separation/alpha spectrometry & 0.015 & 0.25 \\
\hline$\left.{ }^{34}\right|_{\mathrm{Am}}$ & Radiochemical separation/alpha spectrometry & 0.015 & 0.22 \\
\hline Total activity & $\begin{array}{l}\text { Liquid scintillation } \\
{ }^{x} \mathrm{Te} \text { calibration }\end{array}$ & 10 & 10 \\
\hline
\end{tabular}

MDL = method detection limit.

MS - mass spectrometry.

$\mathrm{pCi} / \mathrm{L}$ - picocuries per liter.

Tc $=$ techretium.

TT = thermal ionization

\section{B.7. DATA MANAGEMENT AND REPORTING}

Data obtained from this sampling event shall be managed in accordance with the requirements of the Data Monagement Implementation Plan for the Reindustrialization Program. Oak Rladge, Temmessee (BJC/OR-865, Rev, 2). Results will be provided to the U. S. Environmental Protection Agency, Region 4, and to the Tennessec Department of Environment and Conservation U. S. Department of Energy-Oversight Office.

\section{B.8. REFERENCES}

BJC (Bechtel Jacobs Company LLC) 2006. Data Manogement Implementation Plan for the Reindustrialization Program, Oak Ridge, Tennessee, BJCJOR-865, Rev. 2, Oak Ridge, TN, Augusi. 
EPA (U.S. Envitonmental Protection Agency) 1993. Test Methods for Evoluating Solid Waste, Physical/Chemical Methods SW-\$46, Third Edition (November 1986; Rev. 1, July 1992; Rev. 2, November 1992; and Update 1, August 1993), Office of Solid Waste, Washington, D.C., August. 


\section{APPENDIX A \\ ADDENDUM TO THE \\ BASIC ORDERING AGREEMENT ATTACHMENT 1 \\ STATEMENT OF WORK \\ MINIMUM REQUIREMENTS FOR RADIOCHEMISTRY \\ FOR \\ BECHTEL JACOBS COMPANY, LLC \\ REINDUSTRIALIZATION PROJECT}

09 May 2007 


\section{A.1. INTRODUCTION}

It is the purpose of this addendum to supplement the technical requirements in the Bechtel Jacobs Company, LLC Sample Management Office (BJC SMO) Analytical Suppott Agreement to provide guidance for radiological anslyses on air filter, soil, sludge, floor sweepings, vegetation, animal tissue, and water samples for the Bechtel Jacobs Company, LLC Reindustrialization Project (BJCRP). These samples will be analyzed for the presence of the radionuclides listed in the Target Radionuclide List (TRL) Tables J, 2, and 3 (Attachment I of this addendum) found at the end of this addendum. BJC \$MO retains sole responsibility and authority for authorization/requesting of services. The Subcontractor will be responsible for all authorized/requested analytical activitjes. The Subcontractor shall expect to receive samples starting FY 2001 .

The Subcontractor shall provide the analytical services described above in the context of work elements. These elements, as further explained below, include: radiochenistry analyses, sample accountability and integrity, results reporting, quality assurance/quality control (QA/QC) programs, audits, and technology transfer. These elements and individual activities identified in connection with them are subject to revision to reflect any changes in regulatory or programmatic requirements during the course of contract performance.

\section{A.2, SCOPE}

The subcontractor laboratory shall provide analytical services for the determination of radionuclide constituent activities in the following media: air filter, soil, sludge, floor sweepings, vegetation, animal tissue, and water samples. A project-specific TRL is found in Tables 1,2 , and 3 (Attachment I of this addendum) at the end of this addendum. BJCRP reserves the right to amend the TRL at any time during the period of performance.

Throughout this Addendum, the term shall indicates a requirement, should indicates a recommendation, and may indicates an acceptable practice (neither a recuirement, nor a recommendation). The bidder shall explicitly accept all requirements, or list all exceptions to any requirements of this addendum.

The sampling team will appropriately identify all samples and will submit chain of custody (COC) and analytical request forms with the samples. Because samples may contain radioactive materials, project personnel will perform radiological field surveys of all samples. Any samples 
that show elevated radiation exposure rates will be identified on individual sample tags. No samples that violate U.S. Department of Transportation (DOT) or U.S. Department of Energy (DOE) regulations will be shipped. In addition, any sample containing greater than $70 \mathrm{~Bq}$ per gram of all radionuclides shall be clearly classified, packaged, and shipped according to DOT regulations.

\section{A.3. ORDER RELEASES AND DELIVERY OF RESULTS}

The sample management office (SMO) will place all order releases for sample analyses, under any resulting subcontract by using an appropriate Request for Analysis form. Samples will be delivered or shipped, freight prepaid, to the subcontract laboratory. Analysis results shall be provided to SMO and Science Applications International Corporation (SAIC) within the applicable determination and reporting time. Final data packages shall be provided within 21 calendar days from sample receipt based on tom around time needs and interim stans reports shall be provided within 11 calendar days respectively of sample receipt. Analysis results shall be sent to the attention of both:

Ms. Robin Crabtree

J05 Mitchell Road Suite 202

Oak Ridge, TN 37831
Ms. Teresa Yearwood/

Ms. Tammy Presley

SAlC

301 Laboratory Road

Oak Ridge, TN 37831

\section{A.4. RADIOLOGICAL ANALYSIS ANALYTICAL SUPPORT SERVICES}

This section of the addendum addresses the processing of air filter, soil, sludge, floor sweepings, vegetation, animal tissue, and water samples for the BJCRP. Processing encompasses sample handling, storage, analysis, data review, and reporting.

In support of site investigation activities being conducted by BJCRP, radioanalytical services are being requested through the ICPT and this addendum. These services will include the following:

- COC receipt retum and management of samples and results according to an approved QA program for all laboratory analytical facilities;

sample preparation capabilities for soils and floor sweepings before sample interim storage and sample analysis; 
- radiological analyses for all sample media to include radionuclide-specific analyses and spectral analyses as described in this addendum;

- post-analysis sample storage and proper waste material disposition; and

hard copy and electronic transmittal by disk of analysis results in accordance with specified format and QA requirements. Further details on the analytical and QA requirements in support of this effort are provided below.

\section{A.4.1 ANALYTICAL SERYICES}

The laboratory will be approved by BJCRP for participation under this addendum. BJCRP approval will be given based on results of a procedure review and gamma spectrometry radionuclide library review of SMO certified laboratories. The laboratory needs to provide a copy of all technical procedures and the proposed gamma spectrometry radionuclide library for this review prior to award of subcontract.

Follow the guidance found in Sect. 1.1 of Attachment $J$ to "Basic Ordering Agreement Attachment 1 Statement of Work Minimum Requirements for Radiochemistry" with the addition of the following. Analyses identified in the TRL (Tables 1, 2, and 3, Attachment I of this addendum) shall be conducted in accordance with the specified EPA-600/4-80-032 Prescribed Procedures for Measterement of Radioactivity in Drinking Water, August 1980; EPA SW-846 Test Methods for Evaluating Solid Waste Physical/Chemical Methods, December 1987; EPA 520/5-84-006 Eastem Environmental Radiation Facility Radiochemistry Procedures Manual, August 1984; EML HASL-300 Environmental Measurements Laboratory Procedure Manual, $26^{\text {th }}$ or $27^{\text {th }}$ editions; LA-10300-M Health and Environmental Chemistry: Analytical Techniques, Data Management, and Quality Assurance, October 1996; ISBN-157477-021-7 DOE Methods for Evaluating Environmental and Waste Management Samples - 1997 edition; any appropriate ASTM methods; or any additional project-approved methods. Maximum holding times, QC measures, detection limits, preservation of samples, and data reporting shall comply strictly with those found in Sect. A.4.2 and in Tables 1, 2, and 3 (Attachment I of this addendum). All laboratory analyses must be performed within the allowable bolding times established by the applicable analytical procedure and the addendum.

All results for soil and sediment samples will be reported on a dry-weight basis. The percent moisture will be reported for all solid samples replacing Sect, 1.6 .2 of Attachment $\mathrm{J}$ to Basic 
Orfering Agreement Attachment I Statement of Work Minjmum Requirements for Radiochemistry.

The sample preparation method to be used for this project is total sample dissolution for all analyses except for gamma spectrometry which the samples will be analyzed as is, replacing Sect. 1.6.2 of Attachment $J$ to "Basic Ordering Agreement Attachment 1 Statement of Work Minimum Requirements for Radiochemistry,"

This paragraph replaces Sect. 3.1.2.2 of the "Basic Ordering Agreement Attachment 1 Statement of Work Laboratory Analytical Services." Upon receipt at the laboratory, the samples will be examined immediately to deteninine damage or loss during transport. If problems with samples are determined, this shall be noted on the COC form; otherwise, the COC form shall be marked "RECEIVED IN GOOD CONDITION." The sample condition will be indicated on a Sample Receiving Report (SRR). If samples are damaged or otherwise compromised, the laboratory immediately shall notify Ms. Crabtree by phone (865)241-1368. The samples will be logged in and appropriately maintained in the laboratory until submitted for analyses. After the appropriate laboratory information and required signatures have been added to the $\mathrm{COC}$ and SRR, within 5 working days the laboratory will retum signed copies to BJC SMO to the Project Data Coordinator, and the Project QAOs. In addition, a laboratory-generated report including project sample number, laboratory sample number, and analyses to be performed must be provided with the COC documentation (see also Sect. A.4.3.4 of this addendum). The COC form will be accompanied by an analyses request form.

Upon written notification from the SMO at the end of the project, the laboratory will return copies of all original documentation (excluding magnetic tape) generated as part of the project. All project documentation will be neatly inventoried, listed, page numbered, and boxed.

This paragraph replaces \$ect, 3.1.3.4 of the "Basic Ordering Agreement Attachment I Statement of Work Laboratory Analytical Services." Samples will be archived for 6 months from the submittal of the laboratory analytica] report. If storage beyond this timeframe is necessary it will be communicated to the laboratory prior to samples disposal. 


\section{A.4.2 QUALIYY CONTROL AND DATA REDUCTION REQUIREMENTS}

The following is a description of the minimum QC requirements for laboratory analyses. In this document, "batch" is defined as the group of samples processed at one time in the same area of the laboratory, using the same method. The number of samples in a batch shall not exceed 20 samples. The number of samples in a data package also shall not exceed 20 samples.

\section{A.4.2.1 Holding Times and Preservative Requirements}

(In addition to Sect. 1.2 of Part 1 of Attachment $\mathrm{J}$ to "Basic Ordering Agreement Attachment 1 Statement of Work Minimum Requirements for Radiochemistry.")

Holding time is the time between sample collection and sample analysis. Technical requirements for sample holding times and preservatives have been established. Preservatives are required for water but not for soil matrices. Holding times and preservative requirements for water and soil matrices are as follows:

- Tritium solutions: 6 months, cool to $4^{\circ} \mathrm{C}$ with no preservative and stored in glass.

- Cesium: 6 months; water matrices, preserved to $\mathrm{pH}<2$ in hydrochloric acid

- Plutonium: 6 months, water matrices, when preserved in $2 \mathrm{M}$ nitric acid.

- Other radionuclides: 6 months; water matrices, preserved to $\mathrm{pH}<2$ in nitric or hydrochloric acid.

In addition the maximum sample holding time shall not exceed five half-lives of an unsupported nuclide of interest when five half-lives are shorter than 180 days. Sample specific guidance/requirements may be provided by the SMO for specific isotopes or for very short-lived isotopes.

\section{A.4.2.2 Calibration}

(In addition to the calibration section of Parts 2,3,4, and 6 of Part $l$ of Attachment $J$ to "Basic Ordering Agreement Attachment 1 Statement of Work Minimum Requirements for Radiochemisty.") 
Calibrations and routine system checks are to be petformed according to the following schedule:

1. Initial and Continuing Calibration

a) Alpha and Gamuna Spectroscopy Measurements

Energy versus channel calibration shall be established for spectroscopy systems quarterly or when the daily performance check indicates an unacceptable change in energy gain or zero offșet.

Resolution versus energy calibration shall be established fot gamma spectroscopy systems quarterly or when the daily performance check indicates an unacceptable change in system resolution.

Spectroscopy systems shall be efficiency calibrated for each applicable counting geometry annually or when the daily performance check indicates an unacceptable change in system efficiency. Efficiency verșus energy curves shall be established for ganma spectroscopy systems for the energy region of interest. Single efficiency values may be used for alpha spectroscopy systems for alpha energies between 4.0 and $6.0 \mathrm{MeV}$.

Spectroscopy system backgrounds shall be establișbed quarterly or when the routine performance check indicates an unacceptable change in system background.

\section{b. Gas Flow Proportional and Other Gross Counting Measurements}

The gross counting systems must be efficiency calibrated for each alpha and beta counting geometry at least annually or when the daily performance check indicates an unacceptable change in system efficiency. Self-absorption curves must be developed at least annually, or if the absorption correction is included in an efficiency curve, a new curve must be developed when the dejly performance check indicates an uracceptable change in system efficiency. A plateau curve and alpha/beta cross-talk factors must be established, and a performance check must be made after each P-10 counting gas bottle change. If an unacceptable change has occurred due to the new counting gas, then the new gas must be replaced. 
If, out of necessity, counting is petformed using undesirable counting gas, a special calibration must be performed for that gas.

The counter background must be established quarterly or when the routine performance check indicates an unacceptable change in instrument background. If desired, matrix or batch blanks may be used for background subtraction rather than counter background.

\section{c. Liquid Scintillation Spectrophotometer}

Efficiency quench curves must be established for the liquid scintillation spectrophotometer for each radionuclide to be counted at least annually or when the daily performance check indicates an unacceptable change in system efficiency. Instrument high voltage, gain, energy calibration, or quench indicator calibration must be adjusted using standard instrument calibration sources prior to calibration and routinely (usually daily) thereafter in order to maintain valid quench calibrations over the year. An efficiency calibration is not required when comparative measurement or intercal standardization is used. However, calibration verification shall be performed.

The counter background must be established quarterly or when the noutine performance check indicates an unacceptable change in instrument background. Background quench curves must be established for each radionuclide to be counted unless matrix or batch blanks are used for background subtraction. 


\section{Routine Calibration Verification}

a) Spectroscopy Systems

The energy, resolution, and efficiency calibration shall be checked using a check source each day that the system is used. The check source shall have both low- and high-energy peaks, and the centroid energy, full width at half maximum, and nel counts under each calibration peak (corrected for decay) shall be recorded and should be plotted on a control chart daily.

The counter background shall be checked 1 of every 20 counting periods or daily, whichever is less frequent. The net count rate in each background peak (gamma) or region (alpha) shall be recorded, and should be plotted on a control chart, and shall be compared to the established background spectra used for background subtraction. Acceptable tolerances shall be established for each background peak or region. When tolerance limits are exceeded, or when new background peaks are identified, a new background shall be established for the system.

Acceptable tolerances shall be established for each control chart based on system performance and analytical requirements. When tolerance limits are exceeded, recalibration shall be performed.

b. Gas Flow Proportional and Other Gross Counting Measurements

The efficiency calibration of gross counting systems must be checked using alpha and beta (if applicable) check sources each day that the system is used. The net alpha and beta counts (corrected for decay) and the alpha/beta cross-talk must be recorded and should be plotted on a $Q C$ chart daily.

The counter background must be checked each day that the system is used. The background alpha and beta counts must be recorded and should be plotted on a QC chart daily.

Acccptable tolerances must be established for each QC chart based on system performanee and analytical requirements. Maximum tolerance 
limits of $\pm 10 \%$ of the value determined at time of calibrition are recommended for efficiency verification control charts; otherwise, tolerance limits of \pm 3 standard deviations are recommended. When tolerancc limits are exceeded, recalibration is required.

\section{c. Liquid Scintillation Spectrophotometers}

The efficiency of liquid scintillation spectrophotometers must be checked using a calibration source each day that the system is used. The net counts (corrected for decay) must be recorded and should be plotted on a QC chart daily.

The counter background must be checked each day that the system is used. The background alpha and beta counts must be recorded and should be plotted on a QC chart daily.

Acceptable tolerances must be established for each QC chart based on system performance and analytical requirements. Maximum tolerance limits of $\pm 10 \%$ of the value determined at time of calibration are recommended for efficiency verification control charts; otherwise, tolerance limits of \pm 3 standard deviations are recommended. When tolerance limits are exceeded, recalibration is required.

\section{A.4.2.3 Blanks \\ (Replaces Sect. 2.3.1 of Part 1 of Attachment $J$ to "Basic Ordering Agreement Attachment 1 Statement of Work Minimum Requirements for Radiochemistry.")}

A method blank shall be prepared by the Jaboratory and analyzed with each batch of samples or at a frequency of $5 \%$ of the total samples in the batch, whichever is the higher frequency. The blank shall be introduced into the analytical process before any physical or chemical processing. The results of all method blanks shall be recorded and should be plotted on a control chart daily for each method. Acceptable tolerances shall be established for each control chart based on system performance and analytical requirements.

If the method blank is not used for background subtraction, it shall be used in the following manner in all analyses to ascertain whether sample concentrations reflect contamination: 
- If the absolute value of the concentration of the blank is less than or equal to the associated uncertainty, no correction of sample results is performed.

- If any radionuclide activity concentration in the blank is above the associated uncertainty, the lowest concentration of that radionuclide in the associated samples must be 5 times the blank concentration. Otherwise, all samples associated with the blank that have a radionuclide activity concentration less than 5 times the blank concentration and above the associated uncertainty must be reported (on Form 2 in Attachment II or equivalent) or djscussed in the Case Narrative.

\section{A.4.2.4 Sample Specific Chemical Recovery}

(Replaces Sect. 2.4 of Part 1 of Attachment J to "Bașic Ordering Agreement Attachment I Statement of Work Minimum Requirements for Radiochemistry.")

Laboratory performance on individual samples subject to chemical processing and separation shall be established by spiking each sample with tracer quantities of other radioisotopes of the same element, or carrier quantities of the inactive isotope of the same, or a chemically similar element for all methods possible. Table 4 contains a list of acceptable tracers for use with this project. For all methods possible, samples shall be spiked before both physical and chemical processing. Sample recoveries should be within 10-100\%, but regardless of the recovery the quantity of tracer material used shall be adeçuate to provide a maximum of $10 \%$ uncertainty at the $95 \%$ confidence level in the measured recovery. Each chemical tracer percent recovery shall be reported (on Form 3 in Attachment II or equivalent) and should be plotted on a control chart for each radionuclide and method and should fall within the prescribed limits.

The laboratory shall not comect for any recovery greater than $100 \%$. In case of recovery greater than $100 \%$, the laboratory shall report the sample-specific chemical recovery as determined, but only correct results to $100 \%$. An exception to this requirement may be granted when certified value alpha tracers are used and the laboratory only performs an approximately efficiency caljbration (perhaps not in the exact geometry as the samples or not using a certified standand) only for purposes of calculating the tracer recovery (the tracer serves as the calibration). 
Table 4: Acceptable Tracers or Carriers for Sample-Specific Chemical Recovery

\begin{tabular}{|c|c|}
\hline Radlonuclide of Interest & Acceptable Tracer or Carrier \\
\hline Total Radioactive Sr & ${ }^{85} \mathrm{Sr}$ or Inert Sr \\
\hline${ }^{99} \mathrm{Tc}$ & ${ }^{96} \mathrm{Tc}$ or ${ }^{9511} \mathrm{Tc}$ \\
\hline${ }^{228 / 2306232} \mathrm{Th}$ & ${ }^{234} \mathrm{Th}$ or ${ }^{329} \mathrm{Th}$ \\
\hline${ }^{234 / 235 / 238} \mathrm{U}$ & ${ }^{232} \mathrm{U}$ \\
\hline${ }^{237} \mathrm{~Np}$ & ${ }^{239} \mathrm{~Np}$ \\
\hline${ }^{238 / 239 / 240} \mathrm{Pu}$ & ${ }^{242} \mathrm{Pu}$ or ${ }^{236} \mathrm{Pu}$ \\
\hline${ }^{241} \mathrm{Am}$ & ${ }^{243} \mathrm{Am}$ \\
\hline
\end{tabular}

\section{A.4.2.5 Laboratory Control Sample}

(Replaces Sect. 2.3.2 of Part 1 of Attachment $\mathbf{J}$ to "Basic Ordering Agreement Attachment 1 Statement of Work Minimum Requirements for Radiochemistry.")

The laboratory control sample (LCS) serves as a monitor of the overall performance of all steps in the analysis, including the sample preparation. The LCS concentration shall be greater than 10 times the detection limit activity. At least one sample per batch, or $5 \%$ of the total number of samples, shall be an LCS, whichever is the greater frequency. All LCS results must be within the control limits of $80-120 \%$ for aqueous LCS's and 70-130\% for solid LCS's recovery of the standard value. All LCS results shall be recorded and should be plotted on a control chart according to sample type and radionuclide and shatl fall within the prescribed limits. The LCS may be purchased or prepared by the subcontractor in a similar matrix as the samples being analyzed.

All LCS results and LCS percent recovery (LCS \%R) shall be reported (on Form 4 Attachment II or equivalent). If the results for the LCS fall outside the LCS $\% R$ control limits of 80-120\% for aqueous LCS's and 70-130\% for solid LCS's, the analyses must be terminated, the problem corrected, and the samples associated with that LCS reanalyzed, including redigestion if necessary.

\section{A.4.2.6 Matrix Spike Sample Analysis}

(Replaces Sect. 2.3.4 of Part 1 of Attachment $J$ to "Basic Ordering Agreement Attachment I Statement of Work Minimum Requirements for Radiochemistry,") 
The matrix spike sample analysis provides information about the effect of each sample matrix on the digestion and measurement methodology. \$amples identified as field QC samples cannot be used for spiked sample analysis. When analyses do not hove sample-specific chemical recovery mechanisms (Sect. A.4.2.4), at least one sample per batch, or $\$ \%$ of the total number of samples. shall be a matrix spike, whichever is the greater frequency. Matrix spike sample percent Jecovery (MSS \%R) must be within the limits of 70-130\%. However, spike recovery limits do not apply when the sample concentration exceeds the spike concentration by a factor of 4 or more. The MSS \%R of the matrix spike shall be recorded and plotted on a control chart and shall fall within the prescribed limits.

Under "MSS $\% \mathrm{R}$," the value (to one decimal place) is entered for the percent recovery for all spiked analytes, computed according to the following equation:

$$
\begin{aligned}
& M S S \% R=\frac{(S S R-S R)}{S A} \times 100 \% \\
& \text { where: } \\
& \text { SSR }=\text { Spiked Sample Result } \\
& \text { SR }=\text { Sample Result } \\
& \text { SA }=\text { Spike Added }
\end{aligned}
$$

MSS \%R must be reported, whether it is negative, positive, or zero.

The values for SSR, SR, and SA must be exactly those reported (on Form 5 Attachment II or equivalent). A value of zero must be used for SSR or SR if the radionuclide value is less than zero (0).

In the instance where there is more than one spike sample per matrix and concentration per method per batch, if one spike sample recovery is not within contract criteria, all of the samples of the same matrix, level, and method in the batch must be flagged.

The units (i.e., pCi/L for aqueous and pCi/g dry-weight basis for solid) for reporting spike sample results will be identical to those used for reporting sample results (on Form 1 in Attachment II of this addendum or equivalent). 


\section{A.4.2.7 Duplicate Analysis Samples}

(Replaces Sect. 2.3.3 of Part $\mathrm{I}$ of Attachment $\mathrm{J}$ to "Basic Ordering Agreement Attachment 1 Statement of Work Minimum Requirements for Radiochemistry.")

Duplicate analyses are indicators of laboratory precision. Samples identified as field QC samples cannot be used for duplicate sample analysis. At least one sample per batch, or $5 \%$ of the total number of samples, shall be a duplicate, whichever is the greater frequency. The duplicate samples shall be created by the laboratory after physical processing and mixing and before the chemical processing.

The duplicate error ratio (DER), which is the ratio of the difference between the duplicate results to the propagated 2 standard deviations uncertainties for the sum of the duplicate results, shail be recorded and should be plotted on control charts and shall fall within the control limit set at 1.29.

The relative percent difference (RPD), which is the ratio of the difference between the duplicate results to the average of the duplicate results multiplied by $100 \%$ shall be recorded and should be plotted on control charts and shall fall within the control limits set at $\pm 30 \%$.

The DER and RPD for all radionuclides detected in either the sample or the duplicate are computed according to the following equations:

$$
\begin{aligned}
D E R & =\frac{\mid S-D}{\sqrt{\left(2 \sigma_{s}\right)^{2}+\left(2 \sigma_{0}\right)^{2}}} \\
R P D & =\frac{(S-D)}{\left(\frac{(S+D)}{2}\right)} \times 100 \%
\end{aligned}
$$

where:

$$
\begin{aligned}
& S=\text { First Sample Value } \\
& D=\text { Second Sample Value } \\
& 2 \sigma_{S}=\text { First Sample Uncertainty } \\
& 2 \sigma_{D}=\text { Second Sample Uncertainty }
\end{aligned}
$$

The duplicate analyses results shall be in agreement when either of the DER or RPD criteria are met. The duplicate analyses results shall be reported on Form 6 or equivalent (Attachment II of this addendum). 


\section{A.4.2.8 Method of Calculating Minimum Detection Limits (MDLs)}

(Replaces Sect. 2.6 of Part 1 of Attachment J to "Basic Ordering Agreement Attachment 1 Statement of Work Minimum Requirements for Radiochemistry.")

Required MDLs are given in Tables 1, 2, and 3 Attachment I. MDL is defined below. All samples shall be analyzed using aliquot sizes and counting times that will provide an MDL equal to or less than the required MDL based on a priori calculations. Analyses having an a priori calculated MDL not meeting the required MDL specifications shall be desctibed in the case narrative.

The detection level is an a priori estimate of the smallest quantity that can be measured so that the probabilities for false detection and false nondetection are both $5 \%$. The MDL assumes no interfering nuclide. The MDL is determined according to the following formula':

$$
M D L=k_{a} s_{o}+k_{b} s_{D}
$$

where:

$k_{a}=L .645=$ the value for the upper percentile of the standardized normal vatiate corresponding to the 0.05 risk probability for concluding falsely that activity is present.

$k_{b}=1.645=$ the value for the upper percentile of the standardized normal vaniate corresponding to the $95 \%$ confidence level for detecting the presence of activity.

$S_{0}=$ the standard deviation of the net sample activity when the sample contains none of the constituent of interest at the MDL level.

$S_{D}=$ the standard deviation of the net sample activity when the sample contains the constituent of interest at the MDL.

$S_{\rho}$ and $S_{D}$ may be estimated from the standard deviation of a number of determinations of blanks $\left(\mathrm{S}_{\mathrm{b}}\right)$. When this is done, the $\mathrm{k}_{\mathrm{a}}$ and $\mathrm{k}_{\mathrm{b}}$ shall be replaced by the $\mathrm{t}$ factor appropriate for the number of determinations from the standard Student's $t$ Table. Therefore, the MDL equation reduces to:

\footnotetext{
'Currie, L. A., "Limits for Qualitative Detection and Quantitative Detennination." Analytical Chemistry 40,
} No. 3, (March 1968) p. 589. 


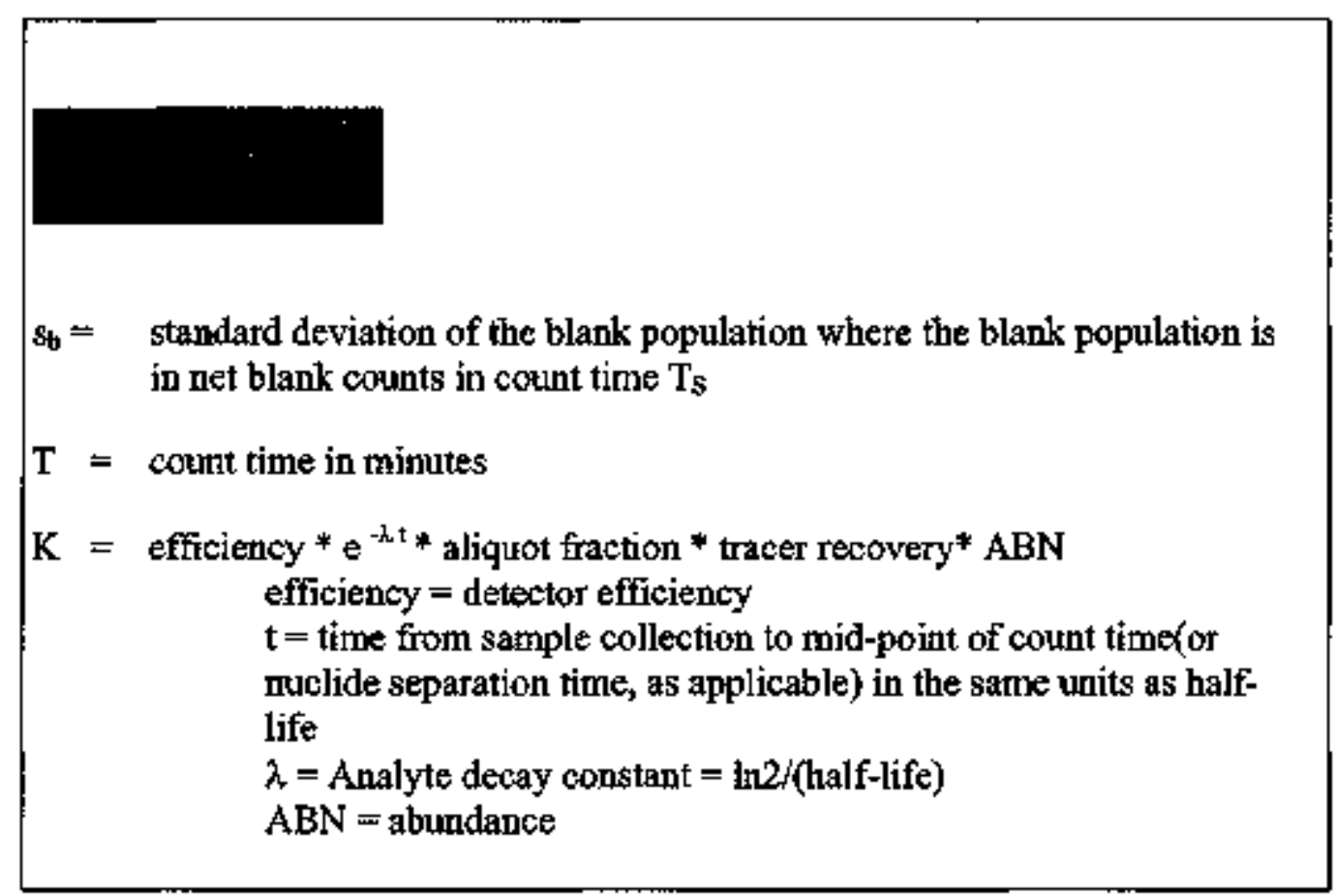

The squuare root of the background shall not be used as an estimate of the standard deviation of the blank.

\section{A.4.2.9 Method of Determining if a Radionuclide is Detected}

The following equation is to be used determine the decision level that will be used for the detection status of a radionuclide of interest:

$$
D L=1.65 \times T P U_{R}
$$

where: $\mathrm{DL}=$ decișion level (dpm/unit)

TPU $U_{R}=$ total propagated uncertainty of the result, $R$ (dpm/urit)

If the radionuclide of interest reported result is less than the decision level (i.e., $1,65 \times T_{\mathrm{TPU}}$ ) for sample flag the result as undetected (U) (on Form 1 in Attachment II or equivalent). 


\section{A.4.2.10 Target Radionuclide List Identiflcation (Gamma Spectroseopy)}

The TRL contains those radionuclides for which a quantitative analysis is required as defined in Table 3 (Attachment I). Therefore, net quantitation with uncertainties shall be provided for all TRL radionuclides whether or not the radionuclide is identified in the peak search and identification. This net quantitation is accomplished by determining the net area in the region associated with the radionuclide when the radionuclide is not detected by the peak search routine. When a peak is detected for the radionuclide, positive identification is achieved through the use of the following criteria:

- Target radionuclide energy must be within $2 \mathrm{keV}$ of the observed peak.

- Gamma spectra of the sample radionuclide must contain $55 \%$ of total gamma abundance of the standard radionuclide library.

\section{A.4.2.11 Tentatively Identified Radionuclides (Gamma Spectroscopy)}

Gamma spectra peaks in radionuclide analyses that are not TRL isotopes are potential tentatively identified radionuclides (TIRs). TIRs must be identified by a radionuclide spectra library search. The identified TIRs shall be quantitated and reported in a peak search nuclide identification repors, but not included on Form 1 .

1. Identified radionuclide energy must be within $2 \mathrm{keV}$ of the observed peak.

2. Gamma spectra of the sample radionuelide and the standard radionuclide library must match according to the following criteria:

a. $55 \%$ of total abundance listed in the standard radionuclide library must be present in the sample spectrum.

b. The sampling-to-count time must not be greater than 10 half-lives of the identified radionuclide.

3. Radionuclide concentrations present in the gamma spectra must be consistent with related radionuclides (e.g., when daughter radionuclides are expected to be in equilibrium with parents, detection of both provides confirmation of identification). 
4. All peaks greater than 3 standard deviations of the background identified radionuclides spectrum should be considered and identified if possible.

5. Guidclines for tcntative identification are as follows:

a. Peaks present in the sample spectrum but not in the reference spectrum shall be reviewed for possible background contamination or interference.

b. When the above criteria are not met, but the gamma spectral interpretation specialist judges the identification to be correct, the identification may be reported.

c. If the gamma spectral interpretation specialist judges the identification to bc uncertain or there are extenuating factors affecting radionuclide identifications, the TIR result may be reported as "unknown."

\section{A.4.3 REPORTING REQUIREMENTS}

\section{A.4.3.1 Radionuclide Quantitation}

(Replaces Sect. 2.5 of Part I of Attachment $J$ to "Basic Ordering Agreement Attachment 1 Statement of Work Minimum Requirements for Radiochemistry.")

Analytical uncertainties shall be reported with all results to qualify the data. For all radionuclide analyses, the result shall be reported as the actual measurement result, whether positive or negativc, with its assocjated $2 \sigma$ unccrtainty. Reporting results as "less than" or as "not detected" is not acceptable. The reported uncertainty shall include all uncertainties associated with the analysis (i.e., total propagated or combined standard uncertainty). So that the number of significant figures reported for results reflect the precision of the analytical technique, the laboratory shall report two significant figures for the uncertainty and the result shall be reported to the same decimal place as the uncertainty.

\section{A.4.3.2 Reporting TImes}

Routine analytical service turnaround, including QA documentation, shall be 21 calendar days, beginning the day of sample receipt at the laboratory and ending the day of data package receipt at the SMO. Dates of receipt and shipment shall be documented by the laboratory. 


\section{A.4.3.3 Data Package}

(In addition to Sect. 2.3.4 of Part $\mathrm{l}$ of Attachment 1 to "Basic Ordering Agreement Attachment $\mathrm{l}$ Statement of Work Data Package Components.")

The laboratory will deliver a complete data package consistent with QC requirements specified in this addendum. All results will be reported on a dry-weight basis for soils and floor sweepings. The percent moisture will be reported for all solid samples. For all requested analyses, the subcontractor laboratory shall provide completed reporting forms (Attachment II of this addendum) and other deliverables as specified in the data packige checklist (Attachment III of this addendum). Although the data forms attached are just example forms, their content shall be required to be in the data package for review.

All paper copy reports shall be certified by the Laboratory QAO and must be signed and dated stating that verification was performed. The paper copy shall be transmitted to BJC SMO using document control procedures (e.g.r transmittal and receipt forms). Before receiving the first. samples, a standard operating procedure shall be developed by the laboratory (and approved by the SMO) that will ensure that the paper copy is correct and that describes document revision procedures once the deliverables are sent to the SMO. The following statement, signed by the Laboratory QAO, shall be included with the report narrative:

\footnotetext{
"The laboratory certifies that all methods and performance criteria used were those described in the applicable SOW developed by BJCRP specifically for this project. Furthermore, that all data outside the project performance criteria has been approved by the Project QAO for this project and that he or she has received a satisfactory (as determined by the Project QAO) explanation."
}

Supporting QC data for these analyses shall be reported for QC analyses required by the addendum and reported on forms supplied by Project Management (Attachment II in this addendum). These QC data shall include all data required by the addendum.

Documentation shall be included with all results to associate the project sample identification number and the laboratory sample identification number to the specific analyses performed for each of these sample identification number combinations. For each reported value, the subcontractor laboratory shall include in the data package all raw data used to obtain that value. The data packages, including the forms in Attachment $D$ of this addendum, and a copy of all raw data shall be provided to the SMO no later than 21 calendar days following sample receipt. The 
raw data (Attachment II) shall include standard, QC, and sample instrument output; lab logbooks sheets; preparation log sheets; sample logging data; external and internal COC sheets; standard preparation logs; run logs; calibration data; calibration veriffeation data, and/or control charts. Instrument output shall include spectral channel counts or spectral peak search and nuclide identification reports. Calibration verification data and/or control charts for background, resolution, energy, and efficiency shall be provided and can be delivered on a project basis. All laboratory QC sample analyses (blanks, spikes, etc.) will be cross-referenced to the applicable environmental and field sample analyses.

Initial calibration and calibration verification on day of initial calibration information shall be provided prior to the shipment of the first samples. Whenever a new intitial calibration is performed, a copy of the new initial calibration and calibration verification information shall be delivered to the project in the same manner as a data package (see Sect. A.3 of this addendum).

The laboratory shall provide a summary status report to the SMO at 11 calendar days after sample receipt. The report will include the number of samples received, the number of analyses and samples completed, the number of analyses in progress and remaining, and any nonconformances or problem areas noted.

\section{A.4.3.4 Chain of Custody}

All $\mathrm{COC}$ forms will be compared with the sample labels on the containers received at the laboratory. An SRR shall be prepared and sent to Project QAO that describes any differences in the COC forms and the sample labels or tags. Other deviations, such as broken or otherwise damaged containers, must be noted on the receiving report. The signed copy of the COC form shall be returtied to the Project Data Coordinator within 5 working days, along with a laboratorygenerated report which includes the project sample number, laboratory sample number, and analyses to be performed (Sect. A.4.1, paragraph 5 of this addendum).

\subsection{CORRECTIVE ACTIONS}

The subcontractor labotatory shall be responsive to corrective actions recommended by BJCRP through the SMO. The laboratory must present a final report to the SMO detailing all corrective actions taken to resolve the deficiencies identified under the performance evaluation. Corrective actions shall be perfomed within 30 days from receipt of a conective action report at the subcontractor laboratory. Failure to correct deficiencies may result in, but not be limited to, the following actions: 
- reduction in the number of samples sent under the addendum;

- suspension of sample shipment;

- additional audits or evaluations; or

- subcontract and/or addendum temination.

Nonconformance Reports (NCR) may be issued to the laboratory and must be either closed or a written response prepared within the negotjated period identified in the NCR. Nonconformances or deficiencies in data deliverables must be resolved before work is accepted. Conected and resubmitted data shall be clearly identified as such by acceptable procedure, which will include, at a minimum, "AMENDED," the NCR number, laboratory manager signature, and date.

NCRs will be cited on all nonconformances, including those identified on SRRs, COCs, and other deliverables. The laboratory shall have a specified period in which to resolve each NCR.

\subsection{RECORDS RETENTION}

The subcontract laboratory shall have a records management program for all record material and data generated by the processes necessary to perform the radiochemical analyses. The records management program shall have, at a minimum, the following:

- written procedures for bandling laboratory records and data throughout their life cycle;

- a system for rapid retrieval of requests for records;

- written records retention and disposition schedules that reflect Federal, State, and local legislative and regulatory requirements;

- criteria for identifying $Q A / Q C$ records and encapsulating $Q A / Q C$ records procedures within the overall records management program.

The subcontract laboratory shall stipulate which record series shall be created and then manage in accordance with the records' life cycles. These records shall, at a minimum, include the following:

- program and policy manuals;

- implementing procedures;

- equipment calibration and maintenance;

- $\quad$ results of all QC performance checks; 
- audit case files, including records management and QA audits; and

- data used in the determination of sample results.

Documentation and records generated by the Subcontract Laboratory for this contract shall be retained on-site by the Subcontract Laboratory for a period not to exceed five calendar years. Records may be sent to BJC SMO at mutually agreed upon intervals. Request for copies of records over and above a reasonable number may be made and will be considered as added scope. No record shall be disposed of by the Subcontract Laboratory at any time during the contract performance without the concurrence of BJC SMO. 


\section{Attachment I}

\section{Target Radionuclide List with Minimum Detection Limits}




\section{Table 1}

Potential Alpha Emitting Target Radionuclides and Reporting Requirements for 21 Calendar Days Turn Around Times"

\begin{tabular}{|c|c|c|c|}
\hline Analysis & Method & $\begin{array}{c}\text { MDL } \\
\text { Water } \\
(\mathrm{pCi} / \mathrm{L})\end{array}$ & $\begin{array}{c}\text { MDL' } \\
\text { Soil, } \\
\text { Sludge, } \\
\text { Floor } \\
\text { Sweepings } \\
\text { (pCi/g) }\end{array}$ \\
\hline${ }^{218} \mathrm{Th}$ & Radiochemical Separation/Alpha Spectrometry & 0.021 & 0.1 \\
\hline${ }^{230} \mathrm{Th}$ & Radiochemical Separation/Alpha Spectrometry & 0.13 & 0.1 \\
\hline${ }^{232} \mathrm{Th}$ & Radiochemical Separation/Alpha Spectrometry & 0.25 & 0.1 \\
\hline${ }^{234} \mathrm{U}$ & Radiochemical Separation/Alpha Spectrometry or TLMS & 0.11 & 0.1 \\
\hline${ }^{235} \mathrm{U}$ & Radiochemical Separation/Ajpha Spectrometry or TI/MS & 0.1 & 0.1 \\
\hline${ }^{238} \mathrm{U}$ & Radiochemical Separation/Alpha Spectrometry or TI/MS & 0.077 & 0.1 \\
\hline${ }^{237} \mathrm{~Np}$ & Radiochemical Separation/Alpha Spectrometry & 0.016 & 0.091 \\
\hline${ }^{238} \mathrm{Pu}$ & Radiochemical Separation/Alpua Spectrometry & 0.016 & 0.27 \\
\hline${ }^{239} \mathrm{Pu}$ & Radiochemical Separation/Alpha Spectrometry & 0.015 & 0.25 \\
\hline${ }^{2 \pi 1} \mathrm{Am}$ & Radiochemical Separation/Alpha Spectrometry & 0.015 & 0.22 \\
\hline
\end{tabular}

${ }^{2}$ MDLs for air filters, Vegetation, and animal tissue will be provided on a case-by-case basis.

bMDLs are based on the availability of $200 \mathrm{~g}$ sample size for soil. 


\section{Table 2}

Potential Beta Emitting Target Radionnclides and Reporting Requirements for 21 Calendar Days Turn Around Times"

\begin{tabular}{|c|l|c|c|}
\hline & & $\begin{array}{c}\text { MDL } \\
\text { Soil, } \\
\text { MDL } \\
\text { Water } \\
\text { Analysis }\end{array}$ & $\begin{array}{c}\text { Mludge, } \\
\text { Floor } \\
\text { Sweepings } \\
\text { (pCi/g) }\end{array}$ \\
\hline${ }^{3} \mathrm{H}$ & $\begin{array}{l}\text { Radiochemical } \\
\text { Separation/Liquid } \\
\text { Seintiliation Counting }\end{array}$ & 580 & 1100 \\
\hline $\begin{array}{c}\text { Total } \\
\text { Radioactive } \\
\text { Sr }\end{array}$ & $\begin{array}{l}\text { Radiochemical } \\
\text { Separation/Beta Count }\end{array}$ & $\mathbf{0 . 0 8 5}$ & $\mathbf{1 . 4}$ \\
\hline${ }^{99} \mathrm{Tc}$ & $\begin{array}{l}\text { Radiochemical } \\
\text { Separation/Bets Count }\end{array}$ & 3.4 & 57 \\
\hline
\end{tabular}

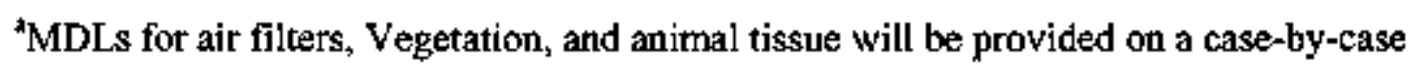
basis.

bMDLs are based on the availability of $200 \mathrm{~g}$ sample size for soil. 
Table 3

Potential Gamma Emitting Target Radionuclides, Gross Anslyses, and Reporting Requirements for 21 Calendar Days Turn Around Times

\begin{tabular}{|c|c|c|c|}
\hline Analysis & Method & $\begin{array}{c}\text { MDL } \\
\text { Water } \\
\text { (pClL) }\end{array}$ & $\begin{array}{c}\text { MDL }^{6} \\
\text { Soil, } \\
\text { Sludge, } \\
\text { Floor } \\
\text { Sweepings } \\
\left(\mathrm{pCl}^{2}\right)\end{array}$ \\
\hline \multicolumn{4}{|c|}{ Gamma Emitters } \\
\hline${ }^{197} \mathrm{Cs}$ & Gammn Spectrometry & 0.15 & 0.1 \\
\hline${ }^{228} \mathrm{Ac}$ & Gamma Spectrometry & 1 & 1 \\
\hline${ }^{234} \mathrm{Th}$ & Gamma Spectrometry & 1 & 1 \\
\hline${ }^{234+m} \mathrm{~Pa}$ & Gamma Spectrometry & $I$ & I \\
\hline \multicolumn{4}{|c|}{ Gross Analvses } \\
\hline $\begin{array}{c}\text { Total } \\
\text { Activity }\end{array}$ & $\begin{array}{l}\text { Liquid Scintillation } \\
{ }^{99} \mathrm{Tc} \text { Calibration } \\
\end{array}$ & 10 & 10 \\
\hline
\end{tabular}

"MDLs for air filters, Vegetation, and animal tissue will be provided on a case-by-case basis.

bMDLs are based on the avaitability of $200 \mathrm{~g}$ sample size for soil.

'The subcontract laboratory shall resolve and quantify unknown mixtures of gammaemitting radionuclides. The nuclides and MDLs listed shall be interpreted as minimum capability; the subcontract laboratory shall detect and quantify unspecified gamma-emitting radjonuclides with a detection limit commensurate with its photon yield and energy, related to the Cs-137 MDL. Project Management may relax the MDLs for individual nuclides in mixtures if requested and justified by the subcontract laboratory. 


\section{Attachment II}

\section{Radiochemical Analysis Data Reporting Forms}




\section{ENVIRONMENTAL SURVEY \\ COVER PAGE \\ RADIOMETRIC DATA ANALYSIS PACKAGE}

Lab Name:

Method Type:
Case No.:

SDG No:

Matrix:

\section{Sample Numbers}

Client ID

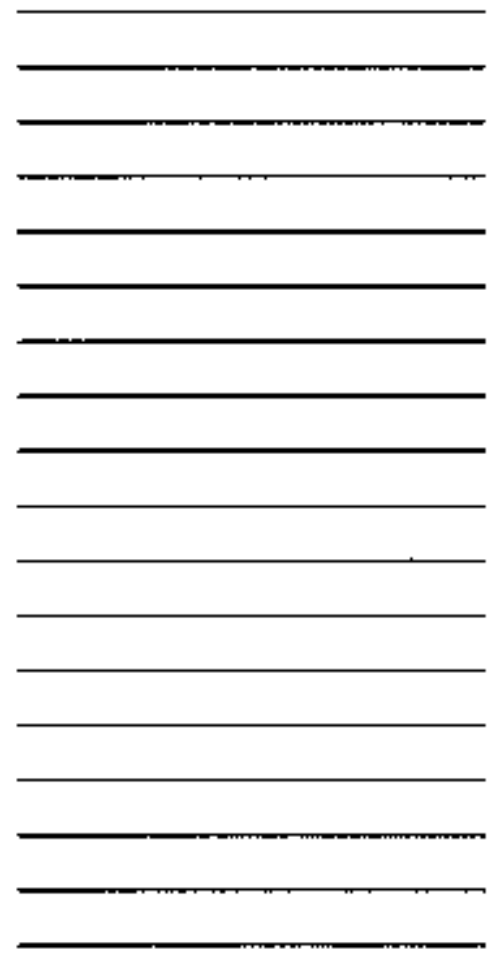

Lab ID No.

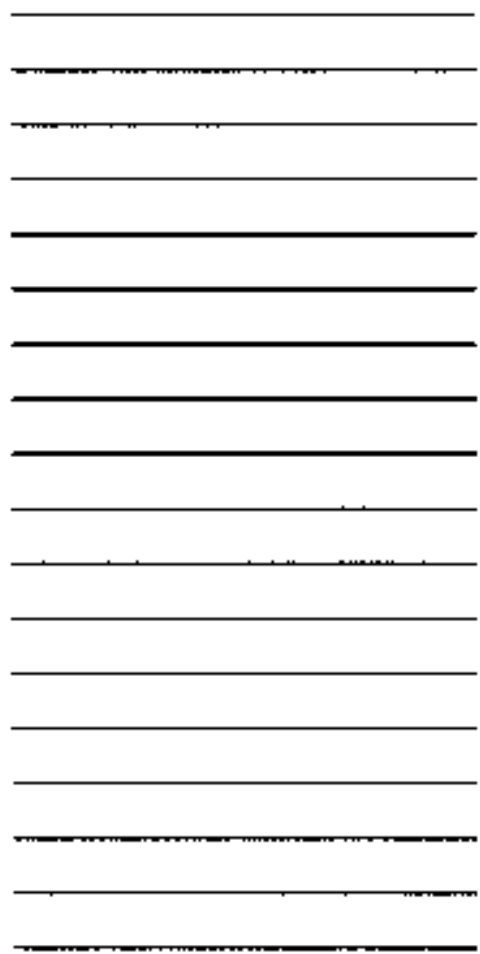

Comments:

Release of the data contained in this data package has been authorized by the laboratory manager or the manager's designee, as verified by the following signature:

Manager, Radjological Laboratory

Date: 


\section{FORM 1}

Date:

Lab Name:

Case No:

Method Type:

SDG No.

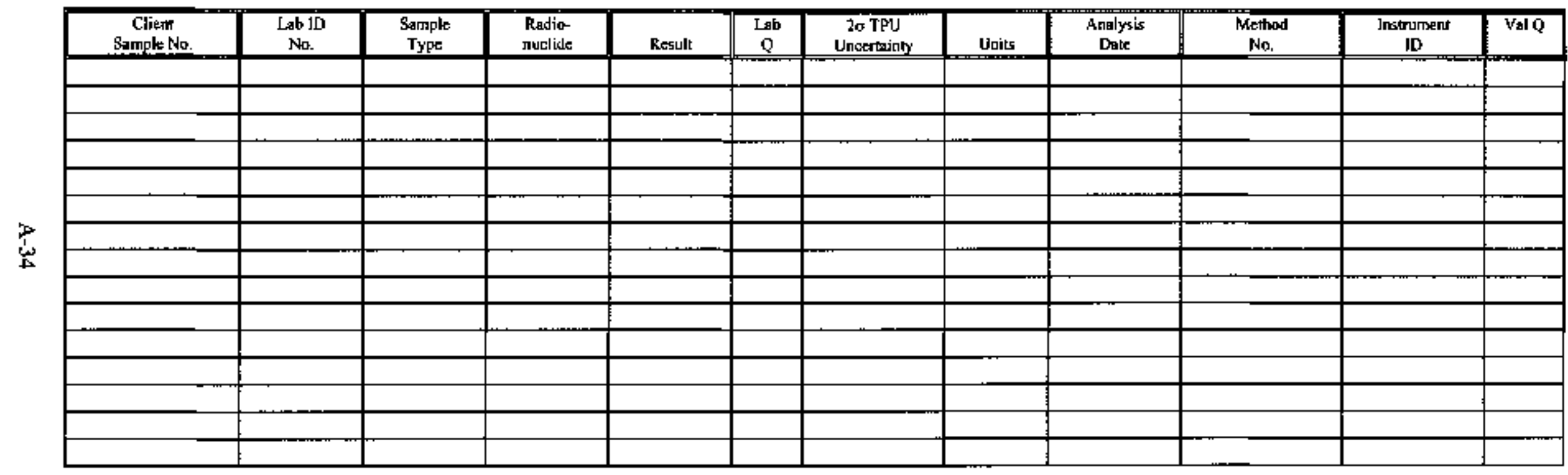

Legend shall be attached.

Comments: 


\section{BLANK SUMMARY \\ FORM 2}

Lab Name:

Lab Sample:

Blank Matrix (soil/water):
Contract:

SDG No.;

Case No.:

Concentration $\mathrm{U}$ gits ( $\mathrm{pCi} / \mathrm{L}$ or $\mathrm{pCi} / \mathrm{g}$ ):

\begin{tabular}{|c|c|c|c|c|c|c|}
\hline $\begin{array}{l}\text { Radjochemical } \\
\text { Determintiation }\end{array}$ & $\begin{array}{l}\text { Method Blank } \\
\text { Result }\end{array}$ & $\begin{array}{l}\text { Method Blank } \\
\text { 2o Uncertainty }\end{array}$ & $\begin{array}{l}\text { Field Blark } \\
\text { Result }\end{array}$ & $\begin{array}{l}\text { Field Blank } \\
\text { 2o Uncentaingy }\end{array}$ & $\begin{array}{c}\text { Trip Blank } \\
\text { Result } \\
\end{array}$ & $\begin{array}{c}\text { Trip Blark } \\
\text { 2a Uncertainly }\end{array}$ \\
\hline & & & & & & \\
\hline & & & & & & \\
\hline & & & & & & \\
\hline & & & & & & \\
\hline & & & & & & \\
\hline & & & & & & \\
\hline & & & & & & \\
\hline & & & & & & \\
\hline & & & & & & \\
\hline & & & & & & \\
\hline & & & & & & \\
\hline & & & & & & \\
\hline & & & & & & \\
\hline & & & & & & \\
\hline & & & & & & \\
\hline & & & & & & \\
\hline
\end{tabular}

Comments: 


\section{CHEMICAL RECOVERY FORM 3}

Lab Name:

Radiochemical Determination;

Sample Matrix (soil/water):
Contract:

SDG No:

Case No.

$$
\mathrm{CT} \% \mathrm{R}=\frac{\mathrm{CT}_{\text {Found }}}{\mathrm{CT}_{\text {True }}} \times 100
$$

Spike Units (pCi or mg) 


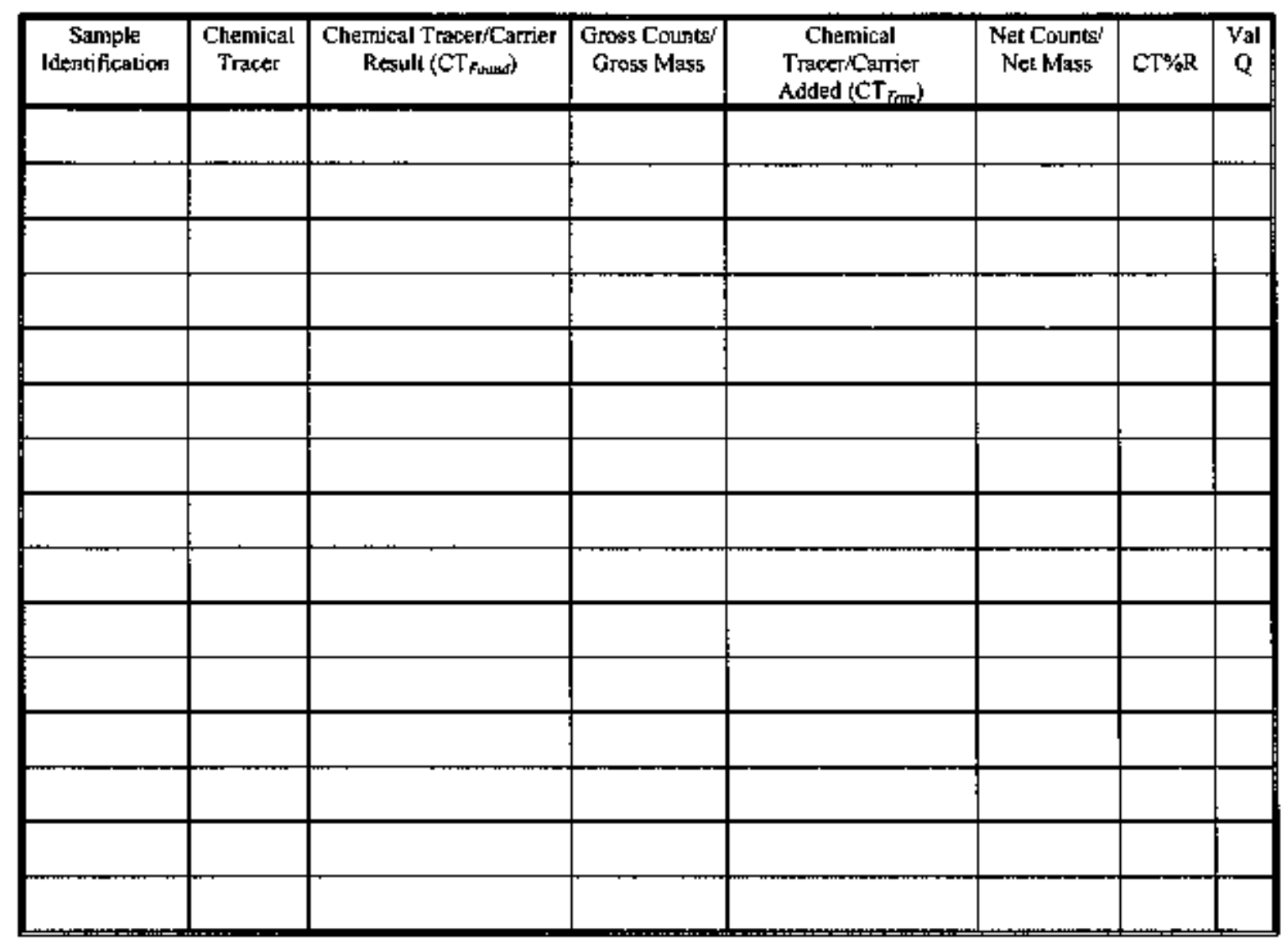

Comments: 


\section{LABORATORY CONTROL SAMPLE FORM 4}

Lab Name:

Lab Sample ID:

Solid LCS Source:

Aqueous LCS Source:
Contract:

Case No:

SDG No:

$$
\mathrm{LCS} \% \mathrm{R}=\frac{\mathrm{LCS}_{\mathrm{Finut}}}{\mathrm{LCS}_{\text {Trxe }}} \times 100
$$

\begin{tabular}{|l|l|l|l|l|l|l|}
\hline \multirow{2}{*}{$\begin{array}{l}\text { Radiochemical } \\
\text { Determination }\end{array}$} & \multicolumn{3}{|c|}{ Aqueous (pCi/L) } & \multicolumn{3}{c|}{ Solid (pCi/g) } \\
\hline & True & Found & LCS \% & True & Found & LCS \%R \\
\hline & & & & & & \\
\hline & & & & & & \\
\hline & & & & & & \\
\hline & & & & & & \\
\hline & & & & & & \\
\hline & & & & & & \\
\hline & & & & & & \\
\hline & & & & & & \\
\hline & & & & & & \\
\hline & & & & & & \\
\hline & & & & & & \\
\hline & & & & & & \\
\hline & & & & & & \\
\hline & & & & & & \\
\hline
\end{tabular}

Comments: 


\section{MATRIX SPIKE SAMPLE RECOVERY \\ FORM 5}

SAMPLE NO.

Lab Name:

Contract:

Lab Sample 1D:

Case No:

Matrix (soil/water):

SDG No.

\% Solids for Sample:

$$
\mathrm{MSS} \% \mathrm{R}=\frac{(\mathrm{SSR}-\mathrm{SR})}{\mathrm{SA}} \times 100
$$

Concentration Units $(\mathrm{pCi} / \mathrm{L}$ or $\mathrm{pCi} / \mathrm{g})$ :

\begin{tabular}{|c|c|c|c|c|c|}
\hline $\begin{array}{l}\text { Radiochemical } \\
\text { Determination }\end{array}$ & $\begin{array}{l}\text { Spiked Sample } \\
\text { Result (SSR) }\end{array}$ & $\begin{array}{l}\text { Sample Result } \\
\text { (SR) }\end{array}$ & $\begin{array}{c}\text { Spike } \\
\text { Added (SA) }\end{array}$ & $\begin{array}{l}\text { MSS } \\
\% R\end{array}$ & $\begin{array}{c}\text { Val } \\
Q\end{array}$ \\
\hline & & & & & \\
\hline & & & & & \\
\hline & & & & & \\
\hline & & & & & \\
\hline & & & & & \\
\hline & & & & & \\
\hline & & & & & \\
\hline & & & & & \\
\hline & & & & & \\
\hline & & & & & \\
\hline & & & & & \\
\hline & & & & & \\
\hline & & & & & \\
\hline & & & & & \\
\hline & & & & & \\
\hline
\end{tabular}

Comments: 


\section{DUPLICATES}

FORM 6

SAMPLE NO.

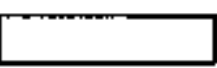

Lab Name:

Lab Sample ID:

Matrix (soil/water);

$\%$ Solids for Sample:

$$
D E R=\frac{|S-D|}{\sqrt{\left(2 \sigma_{5}\right)^{2}+\left(2 \sigma_{D}\right)^{2}}}
$$

\section{Contract:}

Case No:

SDG No:

$\%$ Solids for Duplicate:

$\mathrm{RPD}=\frac{|\mathrm{S}-\mathrm{D}|}{\left(\frac{\mathrm{S}+\mathrm{D}}{2}\right)} \times 100 \%$

\begin{tabular}{|c|c|c|c|c|c|c|c|}
\hline $\begin{array}{l}\text { Radiochemical } \\
\text { Delermination }\end{array}$ & $\begin{array}{c}\text { Sample } \\
\text { Result (S) }\end{array}$ & $\begin{array}{c}\text { Sample } \\
\text { Uncertainty } \\
\left(2 \sigma_{s}\right)\end{array}$ & $\begin{array}{l}\text { Duplicate } \\
\text { Resull (D) }\end{array}$ & $\begin{array}{c}\text { Duplicate } \\
\text { Uncertainty } \\
\left(2 \sigma_{D}\right)\end{array}$ & DER & RPD & $\begin{array}{c}\mathrm{Val} \\
\mathrm{Q}\end{array}$ \\
\hline & & & & & & & \\
\hline & & & & & & & \\
\hline & & & & & & & \\
\hline & & & & & & & \\
\hline & & & & & & & \\
\hline & & & & & & & \\
\hline & & & & & & & \\
\hline & & & & & & & \\
\hline & & & & & & & \\
\hline & & & & & & & \\
\hline & & & & & & & \\
\hline & & & & & & & \\
\hline & & & & & & & \\
\hline & & & & & & & \\
\hline & & & & & & & \\
\hline
\end{tabular}

\section{Comments:}




\section{PREPARATION LOG \\ FORM 7}

Lab Name:

Case No:

Method:
Contract:

SDG No:

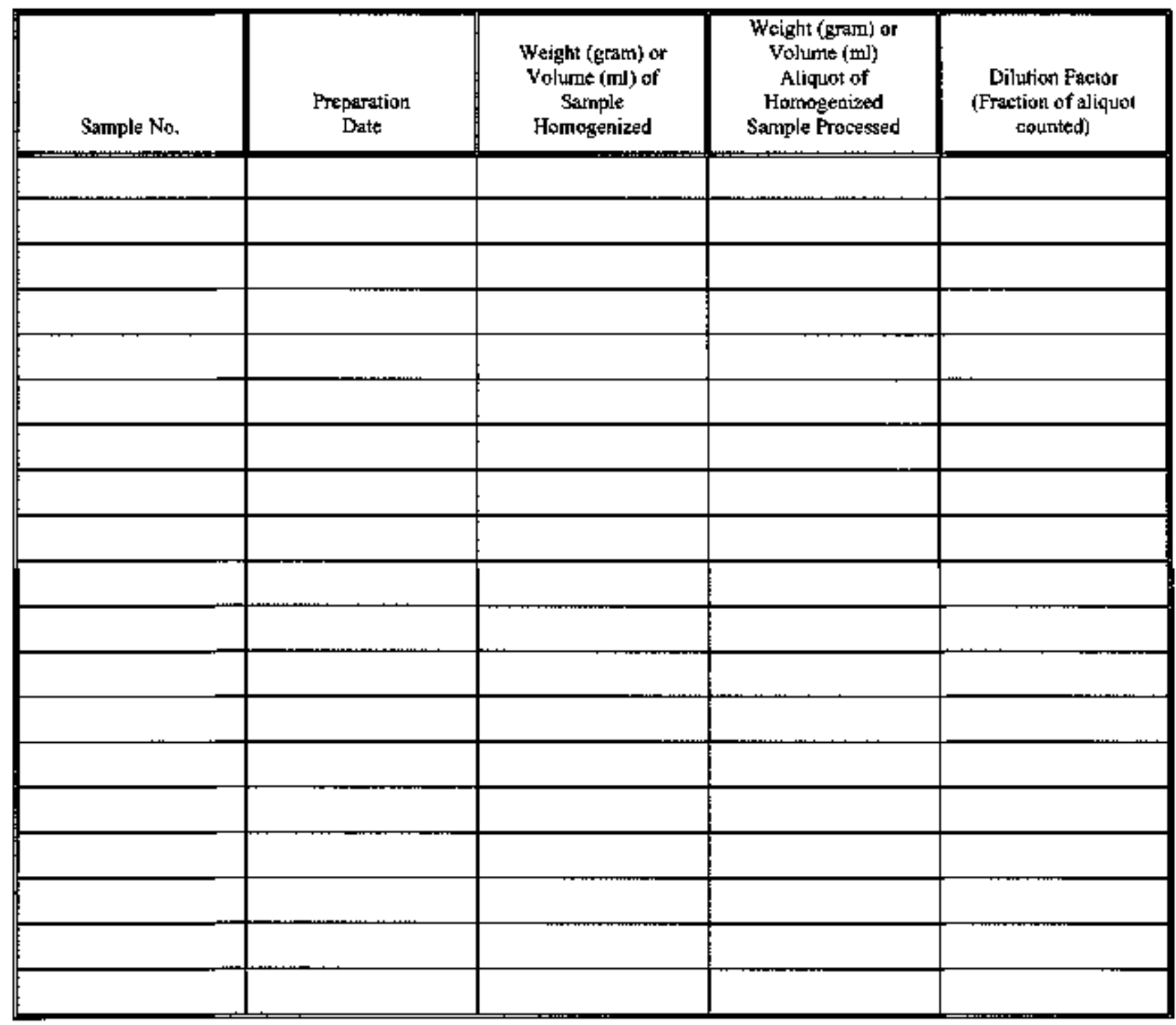

Comments: 


\section{Attachment III}

\section{Radiochemical Analysis Data Package Checklist}




\section{GENERAL INFORMATTON ANALYSES}

DATA PACKAGE CHECKLIST

\begin{tabular}{|c|c|c|c|}
\hline Reportable Item Description & Level C. & Level D & CK \\
\hline $\begin{array}{l}\text { Case Narrative: The case narrative shail discuss what samples } \\
\text { were analyzed along with customer and laboratory identification } \\
\text { aumbers. lt also should contain information on sample matrix, } \\
\text { sample preparation method description, sample chemical method } \\
\text { description, any analysis problems, and any other unusual } \\
\text { characteristics or notations during analysis. }\end{array}$ & $\mathrm{X}$ & $\mathrm{X}$ & \\
\hline $\begin{array}{l}\text { Lab logbooks shects, Preparation log sheets, Run logs, and Sample } \\
\text { logejig data; }\end{array}$ & & $\mathrm{x}$ & \\
\hline Chain of Custody (luteruad and Exterual) & $\mathrm{X}$ & $\mathrm{X}$ & \\
\hline \multicolumn{4}{|l|}{$\begin{array}{l}\text { FORMS (Not all of the forms listed below are applicable } \\
\text { for all analyses. Use only the appropriate forms } \\
\text { for the analyses that were performed.) }\end{array}$} \\
\hline $\begin{array}{l}\text { 1. Form I's: The Analytical Results Form contains the customer } \\
\text { identification, laboratory identification, sample matrix, SDG } \\
\text { number, case number, sample mass or volume used in the } \\
\text { analysis, sample type, sample receipt date, sample anaiysis date, } \\
\text { batch identification, analyle, analytical method, net result, total } \\
\text { propagated uncertainty, MDA, urits, laboratory data qualifier, } \\
\text { and instrument identification. }\end{array}$ & $\mathrm{X}$ & $\bar{x}$ & \\
\hline $\begin{array}{l}\text { 2. Form 2*s: The Blank Summary Form contains blank } \\
\text { identification, biank matrix, SDG number, case number, the net } \\
\text { result, and the associated total propagated uncertainty for each } \\
\text { analysis type for each blsnk sod blank type in the package, snd } \\
\text { units. }\end{array}$ & $\mathrm{X}$ & $\bar{X}$ & \\
\hline $\begin{array}{l}\text { 3. Form 3's: Sample Specific Chemical Recovery Summary Form } \\
\text { contains the customer identification, laboratory identification, } \\
\text { sample matrix, SDG number, case number, chemical tracer } \\
\text { used, amount of chemical tracer added, chemical tracer result } \\
\text { and associated total propagated uncertainty, chemical tracer } \\
\text { percent recovery, units, and laboratory qualifier. For isotopic } \\
\text { tracers: gross counts of tracer and net counts of tracer. For } \\
\text { gravimetric carriers: tare weight for canrier, gross weight for } \\
\text { carrier, and net weight for canier. }\end{array}$ & $\mathrm{X}$ & $\mathrm{X}$ & \\
\hline $\begin{array}{l}\text { 4. Form 4"s: The Laboratory Control Sample Summary Form } \\
\text { contains laboratory control sample identification, SDG number, } \\
\text { case number, laboratory control sample is true value (not } \\
\text { process average value), laboratory control sample is true value } \\
\text { associated error, the laboratory control sample result and } \\
\text { associated total propagated uncertainty, laboratory control } \\
\text { sample matrix, and laboratory control sample percent recovery. }\end{array}$ & $\mathbf{X}$ & $\mathrm{X}$ & \\
\hline
\end{tabular}




\begin{tabular}{|c|c|c|c|}
\hline Reportable Item Description & TSCA & $\begin{array}{l}\text { ENVIRO } \\
\text { CARE }\end{array}$ & CK \\
\hline $\begin{array}{l}\text { 5. Form 5's (if applicable): The Malrix Spike Sample Summaty } \\
\text { Form contains matrix spike sample identification, SDG number, } \\
\text { case number, radionuclide of inlerest, matrix spike added, } \\
\text { original sample result and its associated total propagated } \\
\text { uncertainty, matrix spike sample result and its associated total } \\
\text { propagaled uncertainty, matrix spike sample percent recovery. } \\
\text { units, and laboratory qualifier. (1f there is sample specific } \\
\text { chemical recovery used in the analysis, a MSS is not } \\
\text { required for that analysis.) }\end{array}$ & $\mathrm{X}$ & $\mathrm{X}$ & \\
\hline $\begin{array}{l}\text { 6. Form 6's: The Duplicate Summary Form contains duplicale } \\
\text { sample identification, SDG number, case number, radionuclide } \\
\text { of interest, original sample result and associated total } \\
\text { propagaled uncertainty, duplicate sample result and associated } \\
\text { total propagated uncertainty, sample matrix, and laboratory } \\
\text { qualifier. Calculate DER and RPD. }\end{array}$ & $\mathrm{X}$ & $\mathrm{X}$ & \\
\hline $\begin{array}{l}\text { 7. Form 7's: The Preparation Log Form contains sample } \\
\text { identification, preparation date, preparation method, sample } \\
\text { mass or volume homogenized, Aliquot mass or volume of } \\
\text { homogenized sample processed, dilution factor of aliquol } \\
\text { analyzed. }\end{array}$ & $\mathrm{x}$ & $x$ & \\
\hline \multicolumn{4}{|l|}{ STANDARDS AND TRACERS } \\
\hline $\begin{array}{l}\text { 1. Standard, LCS, MS, and Tracer Certifications showing NIST } \\
\text { tracesbility. }\end{array}$ & & $\bar{x}$ & \\
\hline $\begin{array}{l}\text { 2. Laboratory Standard, LCS, MS, and Tracer Solutions dilution } \\
\text { information showing NIST traceability. }\end{array}$ & & $\mathrm{X}$ & \\
\hline 3. Standard, LCS, MS, and Tracer Solutions Calculation Sheets. & & $\mathrm{X}$ & \\
\hline \multicolumn{4}{|l|}{ CALIBRATION } \\
\hline $\begin{array}{l}\text { L. Initial Calibration results: original calibration counting results, } \\
\text { calibration curve plots and data points, and calibration } \\
\text { uncertainty. }\end{array}$ & & $\bar{X}$ & \\
\hline $\begin{array}{l}\text { 2. Initial count of the continuing calibration check standard and } \\
\text { continuing calibration data and/or continuing calibration control } \\
\text { charts. }\end{array}$ & & $\mathrm{X}$ & \\
\hline
\end{tabular}




\section{ALPHA SPECTROMETRY ANALYSES}

\section{DATA PACKAGE CHECKLIST}

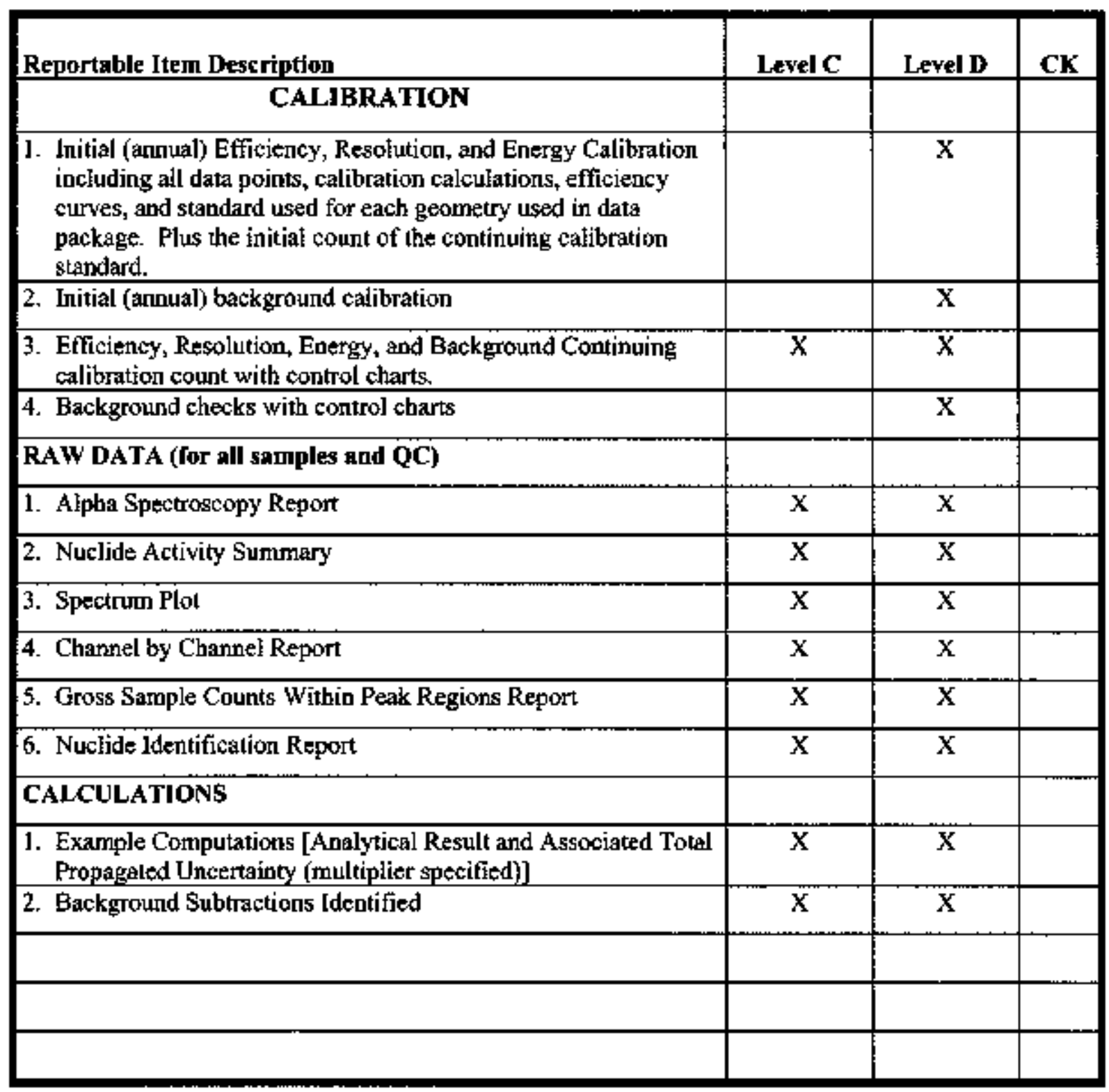




\section{GAMMA SPECTROMETRY ANALYSES}

\section{DATA PACKAGE CHECKLIST}

\begin{tabular}{|c|c|c|c|}
\hline Reportable Item Description & Level C & Level D & CK \\
\hline \multicolumn{4}{|l|}{ CALIBRATION } \\
\hline $\begin{array}{l}\text { 1. Initial (annual) Efficiency, Resolution, and Energy Calibration } \\
\text { including all data points, calibration calculations, efficiency } \\
\text { curves, and standaro used for each geometry used in data } \\
\text { package. Plus the initial count of the continuing colibration } \\
\text { standard. }\end{array}$ & & $\mathrm{X}$ & \\
\hline 2. Inilial (anmual) background calibration & & $\mathbf{X}$ & \\
\hline $\begin{array}{l}\text { 3. Efficiency, Resolution, Energy, and Background Continuing } \\
\text { calibration count with control charts. }\end{array}$ & $\bar{x}$ & $\mathrm{X}$ & \\
\hline 4, Background checks with control charts & & $\mathrm{X}$ & \\
\hline \multicolumn{4}{|l|}{ RAW DATA (for all samples and QC) } \\
\hline I. Peak Search Report & $\mathrm{X}$ & $\mathrm{X}$ & \\
\hline 2. Background Corrected Peak Search Report & $\mathrm{X}$ & $\mathrm{X}$ & \\
\hline 3. Unidentified Energy Line Report & $\mathrm{X}$ & $\mathrm{X}$ & \\
\hline 4. Summary of Nuclide Activity Report & $\mathrm{X}$ & $\mathrm{X}$ & \\
\hline 5. Nucliote Line Activity Report & $\mathrm{X}$ & $\mathrm{X}$ & \\
\hline 6. Summary of Nuclide Activity Report & $\mathrm{X}$ & $\mathrm{X}$ & \\
\hline 7. Rejected Report & $\mathrm{X}$ & $\mathrm{X}$ & \\
\hline 8. Full Combined Activity-MDA Report & $\bar{x}$ & $\mathrm{X}$ & \\
\hline 9. Spectrum Plot & $\mathrm{X}$ & $\mathrm{X}$ & \\
\hline $\begin{array}{l}\text { 10.Channel by Channel Report: Note: If the energy range of the } \\
\text { spectra is provided and the discriminator settings are set below } \\
\text { the energy range, the chanuel by channel teport is not needed. }\end{array}$ & $\mathrm{X}$ & $\mathrm{X}$ & \\
\hline \multicolumn{4}{|l|}{ CALCULATIONS } \\
\hline $\begin{array}{l}\text { 1. Example Computations [Analytical Resull and Associated Total } \\
\text { Propagated Uncertainty (multiplier specified)] }\end{array}$ & $\overrightarrow{\mathrm{x}}$ & $\mathrm{X}$ & \\
\hline 2. Background Subtracions Identified & $\mathrm{X}$ & $\mathrm{X}$ & \\
\hline & & & \\
\hline & & & \\
\hline
\end{tabular}




\section{GAS FLOW PROPORTIONAL COUNTING ANALYSES}

\section{DATA PACKAGE CHECKLIST}

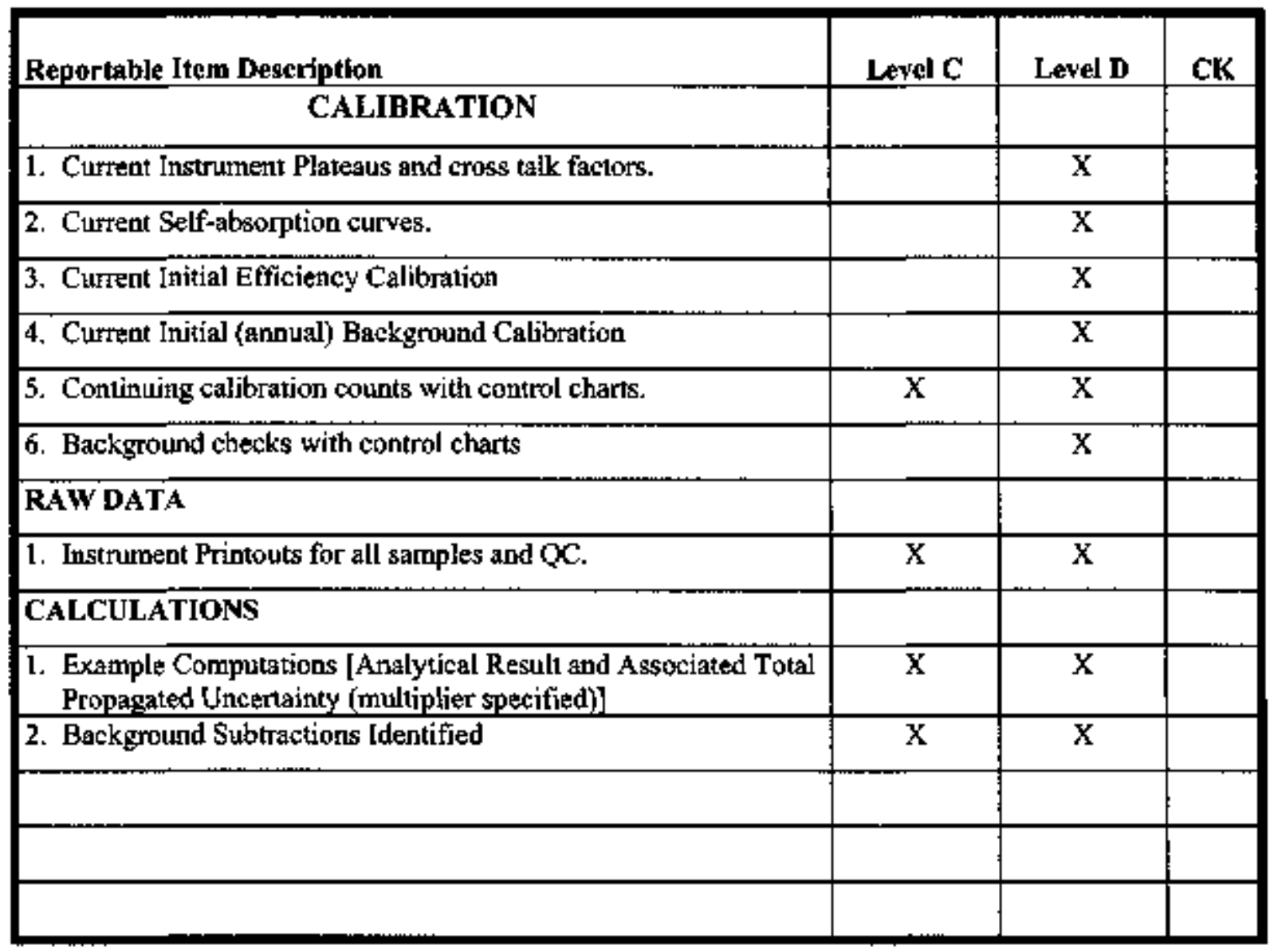




\section{LIQUID SCINTILLATION COUNTING ANALYSES}

\section{DATA PACKAGE CHECKLIST}

\begin{tabular}{|c|c|c|c|}
\hline Reportable Item Description & Level C & Level D & $\mathbf{C K}$ \\
\hline \multicolumn{4}{|l|}{ CALIBRATION } \\
\hline $\begin{array}{l}\text { 1. Efficiency and Background Quench Curves complete with } \\
\text { acceptance timits. }\end{array}$ & & $\mathrm{X}$ & \\
\hline 2. Continuing calibration counts with control charts. & $\mathrm{X}$ & $\mathrm{X}$ & \\
\hline 3. Background checks with control charts & & $\mathrm{X}$ & \\
\hline \multicolumn{4}{|l|}{ RAW DATA } \\
\hline 1. Instrument Printouts & $\mathrm{X}$ & $\mathrm{X}$ & \\
\hline 2. Spectrum Plot & $\bar{X}$ & $\mathrm{x}$ & \\
\hline \multicolumn{4}{|l|}{ CALCULATIONS } \\
\hline $\begin{array}{l}\text { 1. Example Computations [Analytical Result and Associated Total } \\
\text { Propagated Uncertainty (multiptier specified)] }\end{array}$ & $\bar{X}$ & $\bar{X}$ & \\
\hline $\begin{array}{l}\text { 2. Background Subtractions ldentified. If background quench } \\
\text { curves are used they must be provided complete with } \\
\text { acceptance Iirnits. }\end{array}$ & $\mathrm{X}$ & $\bar{X}$ & \\
\hline & & & \\
\hline & & & \\
\hline & & & \\
\hline
\end{tabular}


BJC/OR-2813

\section{DISTRIBUTION}

File-EMEF DMC-RC 


\section{APPENDIX C \\ RADIOLOGICAL SURVEY PLAN FOR THE K-1251 BARGE FACILITY}




\section{C.1. AREA TO BE SURVEYED}

The land parcel to be surveyed consists of approximately 2 acres of land comprising the former K-1251 barge unloading facility at the East Tennessee Tectnology. Park (ETTP). This tract is bounded to the west by the Clinch River. A gravel drive extends on the east side to Bear Creek Road The tract is enclosed by a fence except for the access road that leads form Bear Creek Road. Refer to Fig. C.I for the complete footprint of the survey area.

\section{C.2. HISTORY OF THE AREA}

The land parcel consists of the former K-1251 barge-unloading facility. Historically, the site was used for the storage of uranium hexafluoride $\left(\mathrm{UF}_{6}\right)$ cylinders. Barges carrying loads of $\mathrm{UF}_{6}$ cylinders on the Clinch River would be unloaded and the cylinders stored in an area adjacent to the riverbank. The site is currently inactive and al! equipment, including a large crane, has been removed. Existing documentation indicates that the tract had mimimal involvement with site operations but may have become contaminated via material transfer from the site.

\section{C.3. EXISTING SURVEY AND SAMPLING DATA SUMMARY}

A search of the Bechtel Jacobs Company LLC (BJC) Radiation Control (RADCON) electronic survey data collected between 1996 and 2006 showed one characterization survey, performed during this time frame, associated with the K-1251 facility. The survey, performed in 2000 (200002 ]6KA36147001), consisted of an area survey with a sodium iodide (NaI) detector. The survey results revealed all areas to be less than twice background. Only two locations were time counted. The highest count rate was obtained in the ditch on the north and east sides of the fenced area where a count rate of 10,000 counts per minute $(\mathrm{cpm}$ ) was obtained (background was $5400 \mathrm{cpm}$ ). No other radiological survey data were found.

A seatch of the Oak Ridge Environmental Information System (OREIS) database showed data are available from only one historical soil sample within the $\mathrm{K}-1251$ footprint. The sample from station RAD436 was collected in 1994 and quantified for radionuclides. The results are showa in Table C.l. All detected radionuclide results were below their respective background yalues.

\section{C.4. DATA QUALITY OBJECTIVES PURPOSE}

The purpose of this survey plan is to obtain radiological survey data to detemine the presence of residual contamination in the area through the use of a scoping survey. The data gathered, combined with the process knowledge, will be used to support the lease of the K-[25] facility. The data quality objectives (DQOs) are detailed in the Design of Radiological Surveys (DRS) document ${ }^{t}$ found in Appendix A.

\footnotetext{
${ }^{1}$ Design of Radiological Survey and Sampling to Support Tite Thansfer or Lease of Propertv an the Department of Energy Oath Ridge Resenvation, BJCIOR-554-RI, August 2006.
} 


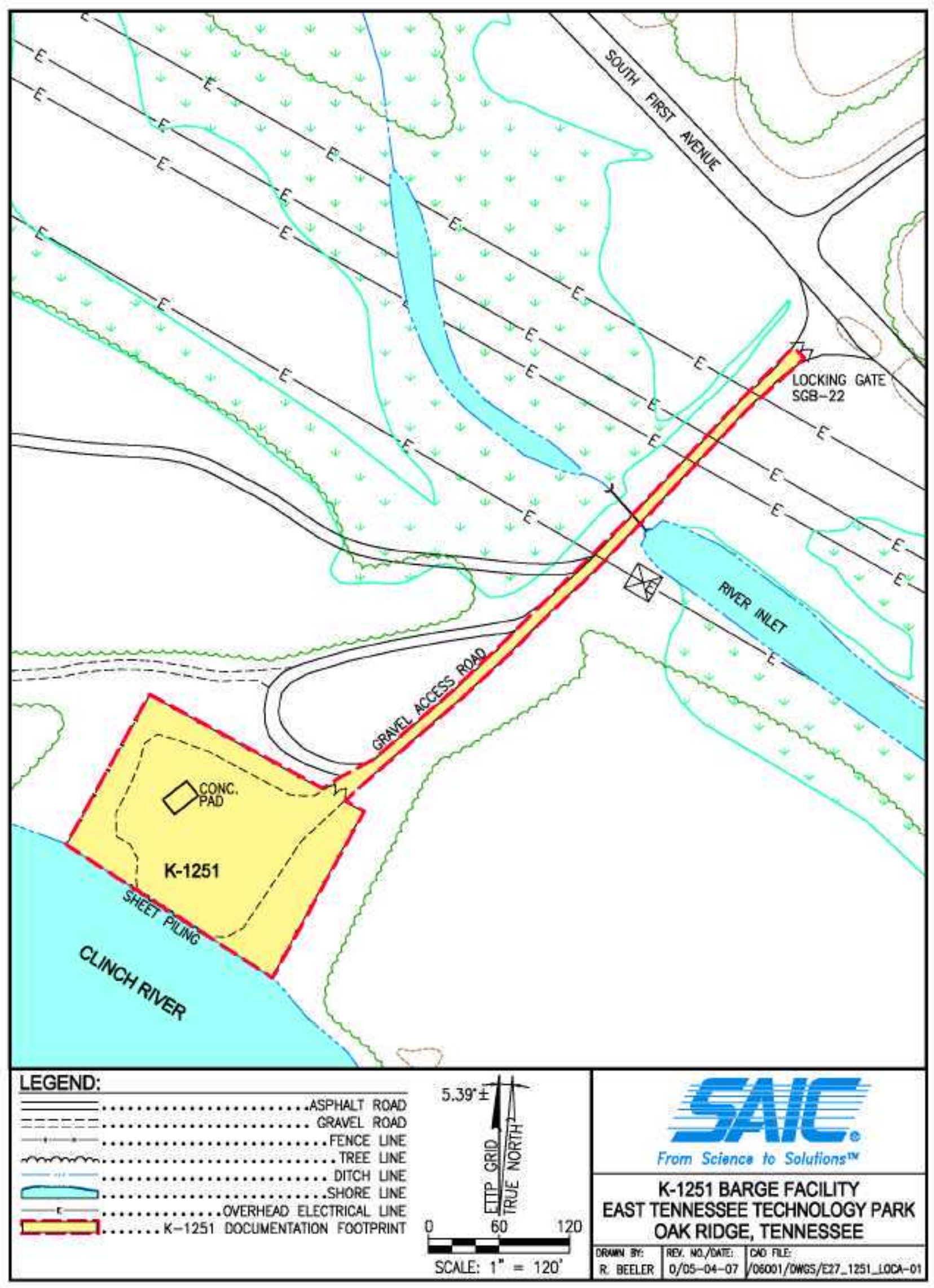

Fig. C.1. K-1251 parcel footprint.

C- 4 


\begin{tabular}{|c|c|c|c|c|c|c|c|c|c|c|c|c|c|c|c|c|}
\hline Sample ID & $\begin{array}{c}\text { Sumple } \\
\text { dept: (ft) }\end{array}$ & $\begin{array}{l}241_{\mathrm{Am}} \\
(\mathrm{pCO} / \mathrm{g})\end{array}$ & 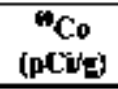 & $\begin{array}{c}{ }^{137} \mathrm{Cs} \\
\text { (pClde) }\end{array}$ & $\begin{array}{l}{ }_{\mathrm{Np}} \\
\mathrm{pCl \textrm {C }})\end{array}$ & $\begin{array}{c}{ }^{20} \mathrm{Pm} \\
\text { (pCig) }\end{array}$ & 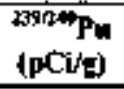 & $\begin{array}{c}{ }^{n} R a \\
\text { (pClg) }\end{array}$ & 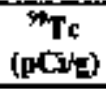 & $\begin{array}{c}\text { 1HTh } \\
\text { (pCWE) }\end{array}$ & $\begin{array}{c}\text { (1)Th } \\
\text { (pCVE) }\end{array}$ & $\begin{array}{c}{ }^{10} \mathrm{Th} \\
\text { (pCWg) }\end{array}$ & $\begin{array}{c}34 \mathrm{Th} \\
\text { (pCitg) }\end{array}$ & $\begin{array}{c}{ }^{2 H} \mathrm{U} \\
(\mathrm{pCi} \cdot \mathrm{g})\end{array}$ & $\begin{array}{c}235 \mathrm{U} \\
\text { (pCUg) }\end{array}$ & 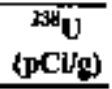 \\
\hline RAD436 & $0-0 \leqslant$ & NA & $0004 \mathrm{U}$ & 0397 & $002 \mathrm{U}$ & $000 \mathrm{U}$ & $0000 \mathrm{U}$ & 021 & $000 \mathrm{U}$ & 0268 & 095 & 0309 & $044 \mathrm{~V}$ & 0303 & 0091 & 032 \\
\hline
\end{tabular}

$N A=$ daca not asalable

Bold = detected vahue exceeds radronuclide background data set Backeround concentratron as defined by Bechtel Jacobs Coinpany LLC in DOE 2003 The background data set thas the

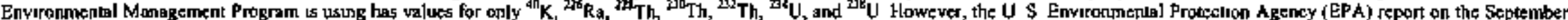

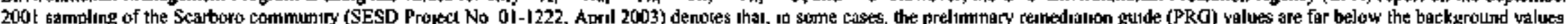

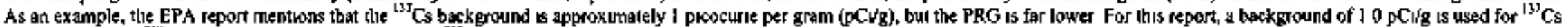

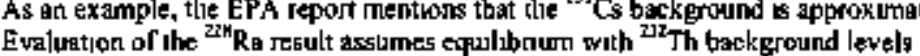

Vatudacion qualifier definttions

Jenotes the agralyte was positivcly identified, the associaled result s the approxinnale concentrabor of the analyte m the sarnple

U denoter the analyie was analyzed for, bul was nor detected above the reported sample quimitualion lumil

UJ depotes the analyte was not detecred above the reported detectron lant, which is approximated duc to quality deficicncy 


\section{C.5. MEASUREMENT TECHNIQUES/SURVEY APPROACH}

\section{C.5.1 RADIONUCLIDES OF CONCERN}

Process history of the ETTP site indicates that uranium (natural, depleted, and/or enriched) would be the most prominent radiological contaminant potentially present in the K-125l land pareel due to contamination from the $\mathrm{UF}_{6}$ cylinders. Urarium-235 entichment levels expected from operations since the early $1960 \mathrm{~s}$ would be anticipated to be between 0.2 to $5.0 \%$. Most cylinders would have potentially contained enrichments of less than $3 \%$.

Other radionuclides $\left({ }^{60} \mathrm{Co},{ }^{137} \mathrm{Cs},{ }^{8990} \mathrm{Sr},{ }^{237} \mathrm{~Np},{ }^{99} \mathrm{~T} \mathrm{c}\right.$, and $\left.{ }^{2382396240} \mathrm{Pu}\right)$ bave also been detected on-site at ETTP. These other radionuclides originated from the introduction of contaminated materials from Oak Ridge National Laboratory andior from the Hanford and Savannab River reactor returns uranium reprocessing program. These radiomuclides are nomally expected to be found in much lower quantities than uranium in process areas. However, transuratics may concentrate it the heal of $\mathrm{UF}_{6}$ cylinders due to their lower volatility and, therefore, contamination at the K-1251 site may have lower uranium to transuranics ratios (U:TRU) than is typical for process buildings. The process building weighted average ${ }^{2}$ ratios are 1140:1 for U:TRU and 350:1 for uranium to technetium-99 (U: $\left.{ }^{.99} \mathrm{Tc}\right)$.

\section{C.5.2 DETERMINATION OF THE RESIDUAL RADIOACTIVITY LIMITS}

The overall goal of this survey is to show that residual contamination exceeding the release criteria is not present in each of the survey units. As shown by modeling, the dose and risk obtained from exposure 10 radioactivity at the U.S. Department of Energy (DOE) surface contamination limits, as set forth in Title 10 Code of Federal Regulations $835^{3}$ and also in DOE Order $5400.5{ }^{4}$ is less that that from the dase and risk criteria, as explained in the design documents. As a result of this modeling, the derived concentration guideline levels (DCGLs) for this survey will be set at the DOE contammation limits for uranium (see Table C.2), which is the dominant contaminant present on-site. For volurnetric or mass measurements such as those commonly seen in water and soil matrices, the DOE Order 5400.5 mandates that the generic guidelines for thorium and radium will be used. Guidelínes for other radionuclides are to be basted on specific survey unit modeling at the $10^{-5}$ risk level while using an industrial worker stenario assurning the unity rule for all radioisotopes based on an established isotopic ratio. A separate limit for the maximum allowable contanination that is concentrated in a smaller area, the derived concentration guideline level elevened measurences somparase (DCGL obtained from an area determined by the number of samples taken in the survey unit and the spacing between them. However for surface contamination measurements, the $\mathrm{DCGL}_{\mathrm{EMC}}$ will be set to three times the appropriate contamination limit, which equates to the contamination averaging criteria as set forth by DOE in 5400.5 for an elevated reading within a 1 square meter $\left(\mathrm{m}^{2}\right)$ maximum size area. For volume contamination, the DCGLemc will be established based on the size of the contaminated area (A) and area factors equal to $\left(100 \mathrm{~m}^{2} / \mathrm{A}\right)^{69}$.

\footnotetext{
I Contracled Health Physcas Techrnician Traning handouts, K-25 \$1te, 1993.

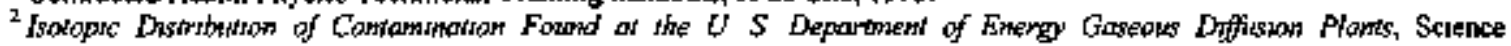
Applications Intemalsonal Copporalien, BJC/OR-257, October 1999.

${ }^{3}$ (CFR I999) 10 Cade of Federat Regutations, entiled Occupatronal Radiatson Protection; the values are taken from Appendix D, "Surface Radioactuvity Valucs."

${ }^{4}$ DOE Order $\$ 400.5$ is entitled Radratron Protection of the Putble and the Erwromment, the values ure taken from Pig IV.1. "Surface Contarmnation Guldelines."
} 
Table C.2. Contaminatton limits (DCGLs) for all survey units

\begin{tabular}{lcc}
\hline & DCGL $\left(\mathrm{dpm} / 100 \mathrm{~cm}^{2}\right)$ & DCGL \\
\hline Total alpha & $($ dpm/area $)$ \\
Removable alpha & 5,000 & 15,000 \\
Total beta-gamma & 1,000 & $\mathrm{~N} / \mathrm{A}$ \\
Removable beta-gamma & 5,000 & 15,000 \\
\hline
\end{tabular}

DCGL = derived concentration gujdeline level.

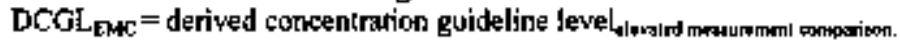

N/A = not applicabte.

\section{C.5.3 IDENTIFICATION OF SURVEY UNITS AND CLASSIFICATIONS}

Under the DRS protocols that are based on Multi-Agency Radiation Survey and Site Investigation Manual (MARSSIM) guidance, artas are classified as cither Class 3, 2, or 1 basted upon historical data and process knowledge. Survey units must be of the same or similar material type-for example, a survey unit cannot contain both asphalt and soil. It would be divided into a survey unit of asphalt and another survey unit of soil. Refer to the design documents for complete descriptions of the different classifications of survey units. An area will be considered to be a Class 3 survey unit if it is not expected to have residual radioactivity levels above $25 \%$ of the DCGL [ 1250 disintegrations per minute per 100 square centimeters (dpm/100 $\mathrm{cm}^{2}$ ) total activity or $250 \mathrm{dpm} / 100 \mathrm{~cm}^{2}$ removable activity]. A Class 2 survey unit is expected to have, or has had, residual radioactivity levels less than the DCGL. A Class 1 survey unit is expected to have, or has had, residual radioactivity levels above the DCGL.

The K-1251 parcel will consist of one land survey unit (LSU) and one exterior survey unit (ESU), as shown in Table C.3. The LSU will be a Class 2 survey unit and consist of the area enclosed by the fence adjacent to the Clinch River and the access road. Historical documentation indicates this area was once utilized as a UF, cylinder storage area. There are no data indicating that spills or accidental releases occurred in this area; thus, contamination levels are not expected to exceed the DCGL. The ESU will be Class 2 survey unit and consist of the concrete pad. Historical knowledge indicates that this area may have once been posted as a radiological contamínation area. However, since it has been downposted, no residual contamination in excess of the DCGL is expected.

Table C.3. Survey undts

\begin{tabular}{lcc}
\hline & Survey Unit & Class \\
\hline LSU I & & Class 2 \\
ESU I & & Class 2 \\
\hline
\end{tabular}

ESU = Exterior survey unit.

LSSU $\sim$ Lattd survey utut

\section{C.5.4 INSTRUMENTATION SELECTION AND SURVEY TECHNIQUES}

Refer to the DRS in Appendix A for details on insirumentation selection. Nal meters and Bicton MicroRem meters will be used for land surveys, as specificd in this survey plan. For exterior surface surveys, alpha scintillation and beta-gamma Geiger-Müeller (GM) detectors, or equivalent, will be attached to scalar rate meters and will bave minimurn detectable activities less than $25 \%$ of the DCGL. Removable contamination surveys (i.e., smear surveys) will be conducted at all locations where exterior surface fixed/total measurements ate taken. All temovable contamination survey smears will be counted on a gas-proportional couster calibrated to detect both alpha and beta-ganna radiations. 
The Waikover team should be equipped with the following:

- Field notebook and writing instruments.

- Maps showing the LSU and assessment locations.

- Global Positioning System (GPS) instument for in-field locating of the assessment locations and for docurnenting locations of notable field observations.

- Survey pin-flags.

- Alpha scintillation and beta-gamma GM detectors, or equivalent, attached to scalas rate meters for exterior surface surveys.

- A Bicron MicroRem meter.

- A 2-in.-diameter by 2-mm-thick Nal detector for surveying assessment locations and possible anthropogenic features, and sediment collection area. If a 2-in.-diameter by 2-mm-thick NaI detector is not available, a 2-in. by 2 -in. $\mathrm{NaI}$ detector may be substituted.

If necessary, the visual inspections and location of assessment points using a GPS unit may be perforned by a separate team prior to the survey measurements. If so, the assessment points and any other locations to be measured (anthropogenic, groundwater runoff, and sediment collection areas) will need to be marked in such a way that the locations can be found by the survey team.

For the Class 2 LSU, systematic Nal walkover survey scans will be performed and will provide $30 \%$ coverage of the area. Any anthropogenic, groundwater runoff, and sediment collection areas recognized during the Nal walkover, and any scan areas determined to have elevated readings, will be marked and timed, fixed-NaI and dose-rate measurements taken at the specifically identified locations of highest scan reading. A fixed $\mathrm{NaI}$ and dose-rate measurements will also be taken al systematic points with a random start location based on a supplied grid.

For the Class 2 ESU, systematic alpha and beta/garuma survey scans will be performed and will provide $50 \%$ coverage of the area. $\mathrm{NaI}$ and dose-rate measurements will also be taken. Any areas recognized during the scan to bave elevated readings will be marked and additional fixed, timed measurements are to be taken at these specifically identified bocations. Timed measurements will also be performed at predetermined, randomly generated points based upon a supplied grid. A dose rate measurement will be perfomed at the center of the area and at any point where other measurements exceed twice background.

All surveys will be perfonmed in accordance with established BJC RADCON procedures (e.g., scan rate, probe distance, and source checks).

\section{C5.5 AREA PREPARATION}

All areas will be surveyed in an "as-found" condition. Materials may be rearranged or moved to allow for survey access to areas covered by material and/or equipment. 


\section{C.5.6 REFERENCE COORDINATE SYSTEM FOR SURVEY}

Class 2 survey units require a sample grıd with systematic measurements taken based upon a random starting point. These survey gnds are based upon the survey unit's area and number of systematic sample measurements required in each.

\section{C.6. SURVEY DESIGN}

\section{C.6.1 QUANTIFY DATA QUALITY OBJECTIVES}

The null hypothesis $\left(\mathrm{H}_{0}\right)$ for each survey unit is that the residial contamination exceeds the DCGL. The alternative hypothesis $\left(\mathrm{H}_{b}\right)$ is that the survey unit meets the DCGL. Decision error levels, as set forth in the design document, are 0.05 for Type $1(\alpha)$ errors and 0.10 for Type Il ( $\beta$ ) errors in all survey units. The Lower Bound of the Gray Region (LBGR) is initjally set to one-balf of the DCGL. These parameters apply to all survey units, regardless of their classification (see Table C.4). The design documents discuss the DQO process in greater detail.

Table C.4. Parameters for computing number of sagoples

\begin{tabular}{|c|c|}
\hline Parameter & Survey design document \\
\hline Type I error rate $(\alpha)$ & 0.05 \\
\hline Type I[ error rate ( $\beta$ ) & 0.50 \\
\hline Non-parametrical stahstical test & Signn' \\
\hline LBGR & $2500 \mathrm{dpm} / 100 \mathrm{~cm}^{2}$ \\
\hline Number of data pounts per survey unit & II \\
\hline
\end{tabular}

\section{C.6.2 DETERMINATION OF THE NUMBER OF DATA POINTS}

There are no bistorical survey results available to use to detennine a standard deviation for this property. However the number of data points for timed NaI and dose measurements will be based on the number of data points required for soil sampling. Because the detection limits expected to be achieved by the laboratory measurements are low relative 10 the DCGL, it is estimated that an LBGR oqual to one-half of the DCGL can be achieved for survey measurements for this project and that a $\Delta / \sigma$ value (also known as the "relative shift") of 3 can be obtained, where $\Delta$ is the DCGL - LBGR, the LBGR is $50 \%$ of the DCGL, and $\sigma$ is the standard deviation of the data. ${ }^{* 0}$ (Note: This is true for survey data but does not apply to sample results from soil.) The Sign test was uilized, as the residual contanination present within the survey units should be at a very small fraction of the DCGL. The MARSSM ${ }^{7}$

\footnotetext{
${ }^{5}$ The WRS staustical test is for usage when the primary coniaminants are found $\mathrm{m}$ background The Sigr test is wo be used when the contaminant is not found in background or when the contaminants and in beckground, but at a small fraction of the DCGL The Signt test witl be used for this survey

"(NRC 1997a). Nuclear Regulatory Commission, Nuclear Regulatory Gulde (NUREG)-1 505, A Propased Nonparanuatrical Stafistical Methodology for the Desigh and Anatysis of Fmat Staftus Decommissoning Surweys, Final Edtion, December 1997.

' (NRC 1997b) Nuclear Regulatory Comminsion, NUREG-1575, Mutt-Agency Radiation Survey and Stie Invexfrgafion Manual (MARSSM), Fina' Editron, December 1997.
} 
recommends that the relative shiff be between 1 and 3. Due to the lack of sampling data associated with the K-125I faelity, a relative shift of 3 was assumed. Therefore, the number of data points per survey unit will be based upon the upper-bound relative shift of 3.0 , and a minimurn of eleven locations (see Table C.4) will be required to characterize each survey unit in the $\mathrm{K}-125 \mathrm{I}$ area.

\section{C.6.3 SURVEY PROCEDURES}

All surveys are to be performed in accordance witb this survey plan, the design documents, and BJC RADCON procedures: ${ }^{k}$ Note: Survey technique is covered in the design doeuments and will not be repeated in this plan. However, variations or clarifications of the design documents will be included.

lin any area in which the survey indicates activity exceeding $5000 \mathrm{dpm} / 100 \mathrm{~cm}^{2}$, direct aipha and beta-garmma measurements will be made following the eslablishment of a $1 \mathrm{~m}^{2}$ grid to obtain data applicable to the DOE Order 5400.5 release critera BJC RADCON procedures will be followed for posting of the immediate area. In addition, any contamination survey location found in excess of two times the DCGL will also have a dose-rate measurement taken at a distance of $3 \mathrm{ft}$.

Any activity in excess of the DCGL, (when averaged over $1 \mathrm{~m}^{2}$ ) will requre that a Class $2 \mathrm{SU}$, or sections thereof, be reclassified as Class 1 and surveyed appropriately.

Many of the radionuclides found on the Oak Ridge Reservation have natural background concentrations. Therefore, background subtraction will be required for all direct field measurements. Some comparison to background levels will also be reguired for the scanning because only a gross signal will be measured. Material-specific backgrounds might be necessary for materials such as tile, brick, and cinderblock because these materials contain elevated levels of naturally occurring radionuclides. For example, the background is $1716 \mathrm{dpm} / 100 \mathrm{~cm}^{2}$ total betaugamma above ambient background for a glazed clay-tile floor, $1103 \mathrm{dpm} / 100 \mathrm{~cm}^{2}$ total beta-gamma above ambient background for a red-clay brick, and $142 \mathrm{dpm} / 100 \mathrm{~cm}^{2}$ total beta-gamna above ambient background for a concrete block using a GM detector. ${ }^{9}$ This level of radioactivity is within that of the nenurally occurring radioactive material contained in the glazed clay-tile/brick/concrete block matrix and will be subtracted from the net ambient readings for these materials before deternining if the result is greater than $25 \%$ of the DCGL or the DCGL.

A summary of the survey requirements for each type of survey unit is found in Table C.5.

\section{C.6.3.1 Exterior Survey Units}

\section{C.6.3.1.1 Class 2 exterior survey units}

The concrete pad is classified as a Class 2 ESU. The Class 2 survey protocols are as follows: The concrete pad will be scan-surveyed using hand-held ajpha scintillation meters and gas-proportional meters and with a NaI meter with $50 \%$ scan coverage. The survey measurement locations for fixed, timed measurements will be systematically chosen per survey grid (see Fig. C.2). In addition, smears and direcl readings will be obtained from locations of the highest contamination with resuls grealer than $25 \%$ of the

\footnotetext{
BPnmanly EH-4516, "Radıacuve Conlamuation Contol and Monilonng." found in BJC-EH-4000, Radhatton Protechost Pragram Descruptan for Bechtel Jacobs Company LLC. Dak Ruder, Tenthesset

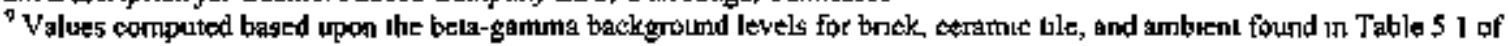
NUREG-1507, Mimmum Defectable Concentrations with Typacat Ractatron Survey Instruments for Variows Contaminamts and Freld Condstrons, December 1997 (NRC 1997b). and an average beta-gamma Geiger-Mueller cortextuon Jactor of 34 (dpm/100 $\left.\mathrm{cm}^{2}\right)$ / $\mathrm{cpm}$ for a planar radjatıon source.
} 
Table C.5. Summary of survey ubit requirements

\begin{tabular}{|c|c|c|c|}
\hline $\begin{array}{c}\text { Survey untt } \\
\text { type }\end{array}$ & Class 3 & Cless 2 & Class 1 \\
\hline Exterioy & & 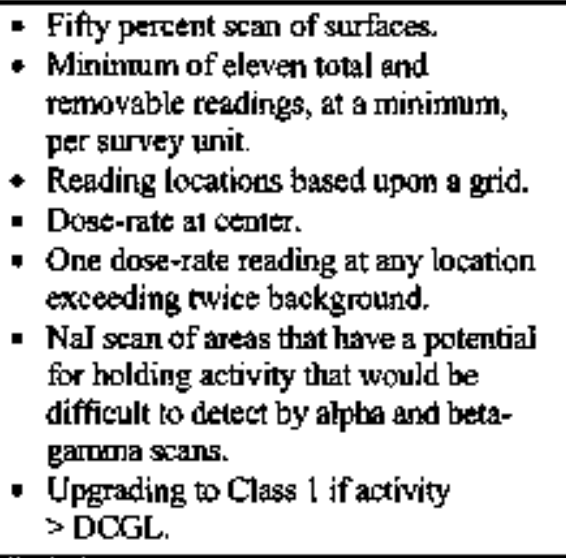 & 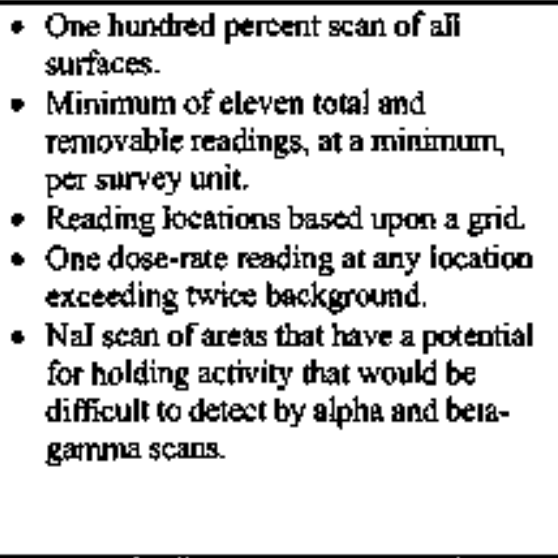 \\
\hline Land & & $\begin{array}{l}\text { Minimum of eleven total timed Nal } \\
\text { coutnts, at a minimum, per survey unit } \\
\text { at systematic points. } \\
\text { - Reading locations based upon a grid. } \\
\text { - Nal walkover survey injon each } \\
\text { survey unit with coverage equal to } \\
30 \% \text { generol areas and lo0\% of } \\
\text { suspect areas. } \\
\text { - Pin flag and make additional timed, } \\
\text { fixed Nal and dose-rate } \\
\text { megsurements at any point found to } \\
\text { be greater than } 3 \text { times ithe } \\
\text { background (or other trigger point) } \\
\text { during the NaI walkover survey. } \\
\text { - One dose-rate reading per every grid } \\
\text { point. } \\
\text { - Upgrade to Class } 1 \text { if activity } \\
>\text { DCGL. }\end{array}$ & $\begin{array}{l}\text { - Minimum of eleven total timed Nal } \\
\text { counts, at a minimum, per servey unit } \\
\text { at systematic points. } \\
\text { - Reading locations based upon a grid } \\
\text { to be determined, as needed. } \\
\text { - Nal walkover survey in/on each } \\
\text { survey unit with lo0\% coverage. } \\
\text { - Pin flag and make additional timed. } \\
\text { fixed Nal and dose-rate } \\
\text { measurements at any point foumd to } \\
\text { be greater than } 3 \text { times the } \\
\text { background during the Nal walkover } \\
\text { survey. } \\
\text { - One dose-rate reading per every grid } \\
\text { point. }\end{array}$ \\
\hline
\end{tabular}

DCGL $=$ derived concentration guideline level.

DCGL, as indicated by the scanning surveys for each borizontal and vertical surface. Any two areas that exceed the DCGL will be reclassified as Class 1 areas and surveyed accordingly. All reclassified areas will be discussed in an addendum to this survey plan that will be issued and included in the survey report and in the facility's baseline environmental condition documentation.

\section{C.6.3.1.2 Class 1 exterlor survey units}

Although there are curently no Class 1 exterior ateas, the potential exists for having a Class 2 area upgraded to a Class 1. Class 1 SUs follow the Class 2 survey protocols, with the exception that $100 \%$ of the surfaces will be scanned. 


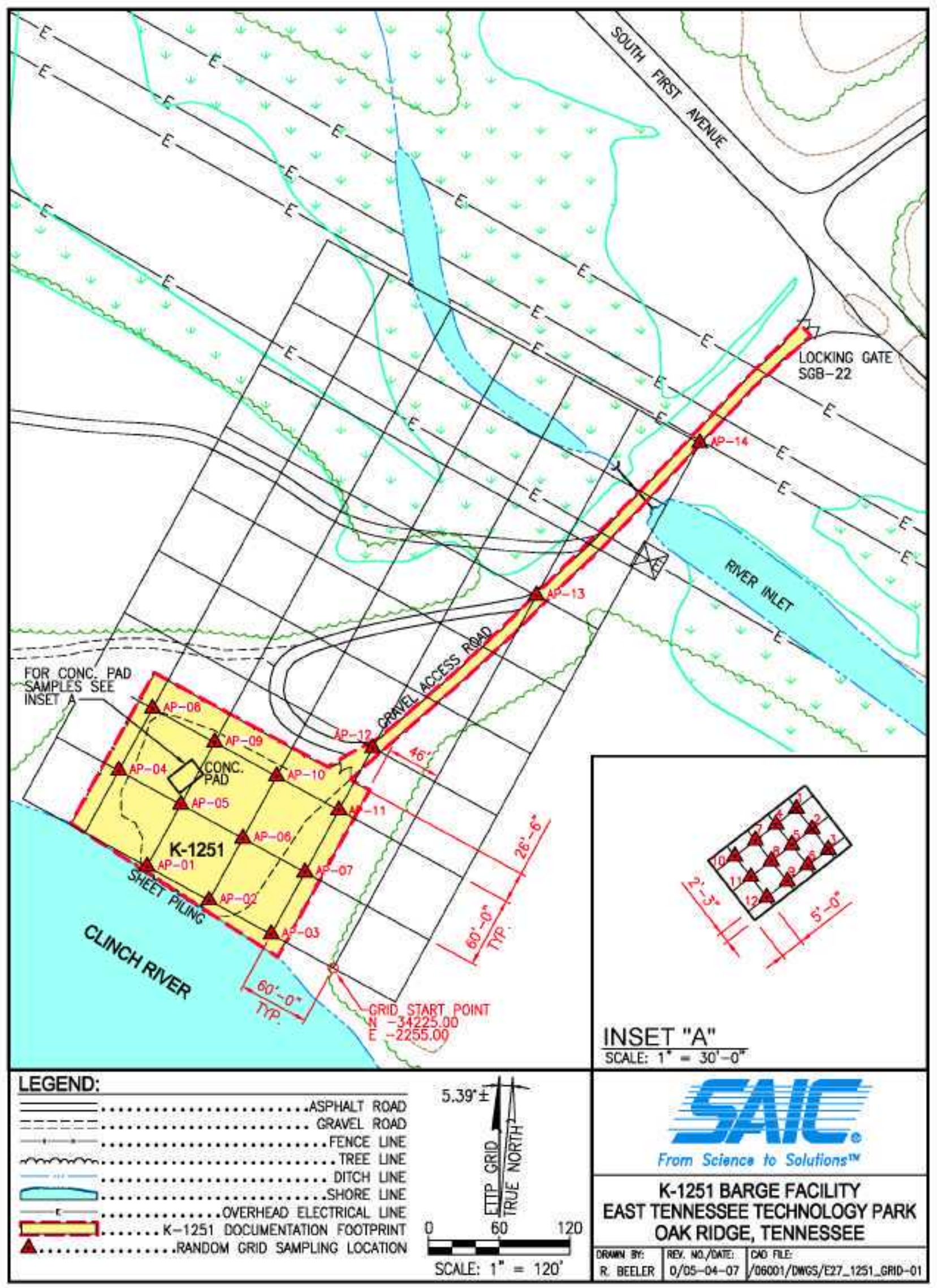

Fig. C.2. K-1251 assessment point locations.

C- 12 


\section{C.6.3.2 Land Survey Units}

A separate sampling plan is being prepared to evaluate soil contamination. Locations of biased sampling for laboratory analysis will be identified and pin flagged by the $\mathrm{NaI}$ walkover survey as described below.

\section{C.6.3.2.1 Closs 2 land survey undts}

Class 2 survey unit survey protocols are as follows. NaI walkover survey judgment scans will be performed with $30 \%$ coverage of the general land areas. Scan with $100 \%$ coverage suspect areas and atcas that are deemed to bave the potential for elevated contamination levels based on professional judgment. Emphasis will be placed on road bed areas, suspect areas of soil or vegetation discoloration, and other areas based on professional judgment. NaI survey measurements will be performed at the fixed grid assessment points, any anthropogenic, groundwater runoff, and sediment collection areas recognized during the $\mathrm{NaI}$ walkover, and any $8 \mathrm{con}$ areas determined to have elevated readings. (Sediment accumulation areas are those areas where overland flow and surface drainage gradients decrease and sediment may accumulate. These aceumulation areas will generally be flat or low-lying areas that would tend to accumulate run-off and any sediments.) The static survey measurement locations will be systernatically chosen per survey grid. A 10 -ft-diameter surface area will be scanned at each of these points with the $\mathrm{NaI}$ detector, and the location of the highest reading will be counted for 1 minute and the results recorded. Locations for collection of biased samples for laboratory analysis will be pin flagged for any location that has a timed $\mathrm{NaI}$ survey reading greater than three times the establisbed background. The basis for the "three times rule" stems from the fact that natural backgrounds vary by up to a factor of three, depending on geology, topography, and other geometric factors. However, the data for each LSU will be reviewed to determine if other areas exist where there is a clear elevation in count rate as compared to surrounding areas but less than three times the establisbed background. Professional judgment will be used to evaluate if the specific geology, topography, and matrix (e.g., rock outcroppings, pavement, severe slopes, and brick buildings) could bave caused the elevated readings. (f a background specific to the geology and topography for the area can be obtained, a lower trigget level (e.g. two times the background or the $99 \%$ decision level for the Nal meter) nay be used based on professional judgrnent.

The measurements at each point will include fixed, timed $\mathrm{NaI}$ and dose-rate measurements. Any Class 2 areas that exceed the DCGL will be reclassified as Class 1 areas and surveyed accordingly. All reclassified areas will be discussed in the survey report and the Baseline Environmental Analysis Report (BEAR) Chap. 6, "Survey Results."

\section{C.6.3.2.2 Class 1 land survey units}

Although there are currently no Class 1 land areas, the potential exists for having a Class 2 area upgraded to a Class 1 . The Class 1 survey units follow the Class 2 survey protocols, with the exception that $100 \%$ of the accessible surface will be scanned with the NaI meter.

\section{C.6.A SPECIFICATION OF SAMPLING LOCATIONS}

Systematic assessment points will be based on the survey grid as shown on Fie. C.2. The ESU assessnent points are at a distance relative to the eorrer of the concrete pad. For LSU assessment points, the state plane system coordinates and longitude/latitude for each assessment point for LSU I are shown in Table C.6. In addition, the walkover inspection team will identify anthropogenic, groundwater nunoff, and sediment accumulation areas, and any otber areas scanmed above background in the LSUs, as biased assessunent points. 
Table C.6. Assessment point Jocatlons for LSE 2

\begin{tabular}{|c|c|c|c|c|c|c|}
\hline $\begin{array}{c}\text { Assessment } \\
\text { point } \\
\text { number }\end{array}$ & $\begin{array}{c}\text { Oak RHge } \\
\text { administrative } \\
\text { grid } \\
\text { easting }\end{array}$ & $\begin{array}{c}\text { Oak Ridge } \\
\text { administrative } \\
\text { grfd } \\
\text { northing } \\
\end{array}$ & $\begin{array}{c}\text { Tennessee } \\
\text { State grind } \\
\text { Easting }\end{array}$ & $\begin{array}{l}\text { Tennessee } \\
\text { State grtd } \\
\text { northing }\end{array}$ & Latitude & Lanpitude \\
\hline$A P-0 l$ & -2413.0467 & -34138.8534 & 2443365.164 & 578002.8507 & 84.396362 & $35.91054 \mathrm{l}$ \\
\hline$A P=02$ & -2360.3645 & $-34167, \$ 690$ & 2443420.685 & 577980.1209 & 84,396176 & 35,910476 \\
\hline$A P-03$ & -2307.6822 & -34196.2845 & 2443476.207 & 577957.3913 & 84.395990 & 35.910412 \\
\hline$A P-04$ & -2437.0135 & -34057.4557 & 2443332.372 & 578081.1019 & 84.396469 & 35.910758 \\
\hline$A P-05$ & .2384 .3312 & -34086.1712 & 2443387.894 & 578058.3723 & 84,396283 & 35.910693 \\
\hline AP॰06 & .2331 .6490 & $-341 \mid 4.8867$ & 2443443.415 & 578035.6426 & 84,396096 & 35.910628 \\
\hline $\mathrm{AP}\lrcorner 07$ & -2278.9667 & -34143.6022 & 2443498.937 & 578012.9129 & 84.395910 & 35.910563 \\
\hline$A P-08$ & -2408.2979 & -34004.7734 & 2443355.102 & $\$ 78136.6236$ & 64.396389 & 35.910909 \\
\hline AP- 09 & -2355.6157 & -34033.4890 & 2443410,623 & 578113.8938 & 84396203 & 35.910844 \\
\hline AP- 10 & -2302.9335 & -34062.2045 & 2443466.145 & 578091.1641 & 84.396017 & 35.910779 \\
\hline$A P-11$ & -2250.2512 & -34090.9200 & 2443521.666 & 578068.4345 & 84,395830 & 35.910714 \\
\hline AP. 12 & .2221 .5357 & -34038.2377 & 2443544,396 & 578123.9561 & 84,395750 & 35.910866 \\
\hline AP- 13 & -2082.7069 & -33908.9065 & 2443668.107 & 578267.7912 & 84395325 & 35.911255 \\
\hline AP-14 & -1943.8781 & -33779.5753 & 2443791.817 & $5784 J 1.6264$ & 84.394899 & 35.911645 \\
\hline
\end{tabular}

LSU $\times$ a land survey unit.

\section{C.7. DOCUMENTATION}

Survey data will be documented in accordance with the procedures and revicws required by the DOE Contractor. A report will be prepared, describing the survey methods, results, and evaluation. The report will include the findings of the assessment, describe the materials surveyed and their condition, and justify the contamination potential classification assigned. The data evaluation will be included, along with the assessment of the quality assurance/quality control $(\mathrm{QA} / \mathrm{QC})$ documentation. This report, of a summary of the report, will also be included and referenced in the facility's baseline environmental conditions documentation.

\section{C.8. QUALITY ASSURANCE}

All appropriate QA/QC reviews to ensure the quality of the data gathered will be performed and documented.

Survey instruments and metbods specified in applicable RADCON operating and technical procedures have been documented as to their ability to provide a $95 \%$ confidence level in detection of surface contamination at levels that meet the requirements of this protocol. Supporting data ase provided on each survey form.

Radiological Control Technicians not involved in the execution of this protocol will repeat approximately $5 \%$ of the direct and removable activity measurements on items destined for unrestricted release for verification. The results most confum the initial findings for acceptance as satisfying release criteria. 
A DOE Contractor RADCON-Certified Health Physicist, or another designated health physicist, will review, evaluate, and validate the survey results, including assessment of the $Q A / Q C$ information and data, prior to generalion of the radiologicat survey report. The final radiological survey report will include the details of this assessment It will be provided to the DOE Contractor project QA manager, project manager. and site project health physicist for approval prior to its inclusion into the BEAR. 
APPENDIX D

WALKOVER INSPECTION PROTOCOL 


\section{CLASS 3 AND CLASS 4 SOIL UNIT WALKOVER INSPECTION PROTOCOL}

\section{Purpese}

The DVS defines a Class 3 SU as an eren of land at ETTP that:

- is, or was, impacted;

- has no or very low potential for COC concentrations to exceed remediation levels (RLs), tisk. based levels, or be a source of groundwater contanination; and

- there is insufficient evidence to support a no-action decision. inpacts.

The DVS defines a Class 4 SU as an area of lend at ETTP that has no evident antoropogenic

The pirpose of the Class 3 and Class 4 SU walkover inspections will be to visually inspect Class 3 and Class 4 SUs to collect observations and screening tata to support the no-ation decision. The inspections will fociss on jdentifying any anthropogenic features delineating the boundaries of the features and detemining if sampling of the feature is warranted. Surface water run-off and sediment accumulation areas will also be identified for sampling by the inspection teams.

\section{Personoel}

Walkover Inspection Personnel. A minimurn of two people will conduct each geophysical investightion. One or both of these peopie will, at a minimum:

- bave knowledge of ETTP site activities;

- be trained in the use of a field notebook for reconfing observations;

- have the background and experience necessary to identify anthropogenic features such as soil or rubble deposits;

- be trained in the use of global positioning system (GPS) instruments; and

- be trained in the use of the FDLER radiation detestor.

Sample Collection Persannel. A minimum of two people will collect soil samples from selected areas identified during the watkover inspection. One or both of these people will, at a minimum:

- be trained in collection of soil saraples;

- be trained in the use of a fietd notebook for recording observations; and

- be trained in the use of GPS instruments.

Equiprent. The walkover tean will be equipped with the following:

- field notebook and writing instruments;

- maps andor aerial photographs showing the SU to be inspected and the assessment locations;

- GPS instrument for in-field locating of the walkover inspection team, assessment locations, and for documenting locations of notable field obiservations;

- survey pin-flags;

- compass or other directional device; and

- FIDLER radiation detector for surveying assessment locations and possible anthropogenic feakures; and 
- appropriate personal protection equiptnent (PPE) as specified in a prepered safaty and health plan (SHP) and its activity hezards analysis (AHA).

The sompling team will be equipped with all of the necessary equipment for coltecting soil samples from the depth interval of 0 to 32 inches below ground surface (bgs) as specified in projectapproved soll sampie collection procedures and as described in project-specific work plans.

\section{Special Congiderattoss.}

1. All work will be conducted in a safe manner consistent with a prepared SHP and its AHA.

2. Walkover investigations and sample collection should be condweied besween mid-fall and early spring when vegetation is at a minimum. This will entance safety and maximize the ability to make observations and use GPS.

Procedure.

1. A technical tean, that includes one or more members of the field teams, will examine maps and aerial photographs of the Class 3 and Clnss 4 SUs to be inspected. A systematic grid, with random start location, will be caiculated with an average assessment location density of one location per acte. The grid will be overlain on field-ready maps of the SUs to be inspected.

2. Walkover maps should be annotated with state plane coordinates of the anticipated uransects. Coordinates should be reported in the same coordinate system used by the field GPS instrument.

3. An action level for the FIDLER detector will be determined prior to performing an assessment. A description of the action level and how it was determined will be presented in the project-specific work plans.

4. The walkover intpection tean will assemble all of its equipment and make sure the equipment is in proper worting order prior to taking it to the field.

5. Each day while in the fieid, but prior to beginning the walkover, the walkover team will:

- review the AHA for their work;

- calibrate their equipment;

- take three readings of the ambient radiation with the FIDLER detector and recond the average value of the three readings in the field notebook as the radiation backsround reading;

- recoed in the field notebook time, weather, and personnel present; and

- recoed in the field notebook any abservations that could influence the interpretation of the walkover survey.

6. The walkover inspection teasp will walk to each randomb selected assessment location. Upon reaching the location, the walkover inspection team will describe the area in the field notebook, making note of eny unusual or anthropogenic feanures. The walkover inspection tean will aiso survey a lo-foot diameter surface area at the location with the FIDLER detector and record the range of readings in the field notebook.

7. While traversing routes to assessment locations and at the assessment locations themselves, the walkover inspection tean wilt take note of any unusual or anthropogeric feantes, plant flags at locations selected for subsequent soil sampling associated with each feature, and survey each fenture with the FIDLER detector. The following information will be recorded in the field notebook for each such fenturo:

- description of the anthropogenic feature;

- coordinates of the feature boundary from the GPS instrument;

- range of survey readings teken from the FIDL.ER detector.

- a clear description of any parts of the feature whose FIDLER survey reading exceds the pre. determined action level; and

- any observations that may influence the interpretation of the visual and radiation surveys.

$$
\text { D. } 4
$$


8. The walkover inspection team will use professional jadgenent to select soil sampling locations and will take into account results fom the FIDLER survey, visible anthropogenic materials, soil staining or discoloration, and stressed vegetalion.

9. During the walkover inspection, the walkover inspection team will identify sediment accumulation ares in the Class 3 and Class 4 SUs. Sediment tecumulation areas are those areas where overland flow and surface drainege gradients decrease and sediment may accumulate. These accumulation areas will generally be flat or low lying areas that would tend to accumulate rum-off and any associated sedinents.

10. The walkover jospection team will select sample locations within the accumulation ereas that will provide representative matcrials for the areas, plant a fleg at ach selected sedinent accursulation aren sample location, recond the approximale beundary of the area on the map, determine and recond in the field notebook the coordinates of the selected sedimeat sample locations based on the GPS instrumetint, assign a sample location ID number according to the project protocol, and recerd that number on the sample location flag and in the field logbonk.

11. Following the walkover inspection, a sampling tean will retum to each soil sampling location, including sediment accumulation areas, and coltect sufficient sample mass at each location for analysis. Sampiling and analysis will follow projłect-specific work plans.

12. Soil samples will be transported to the appropriate laboratory as described in the project-specific work plan.

13. Following completion of field activities and retum of aralytical resulta, the BlC technical team will prepere documentation describjag the findings of the walkover inspection. The teport will include the reconded infonoation on each feature noted by the field tearn and the laboratory analytical results. Based on the findings of the technical team, a recommendation will be made as to whether the SUs, of any part of them, need to be reclassified. 


\section{APPENDIX E}

\section{RISK EVALUATION FOR THE K-1251 BARGE FACILITY}




\section{CONTENTS}

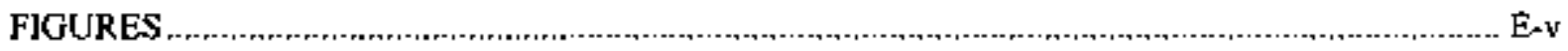

TABLES

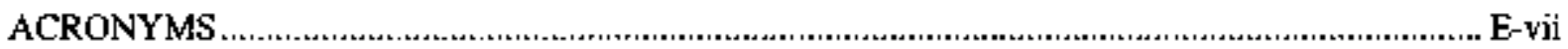

EXECUTIVE SUMMARY

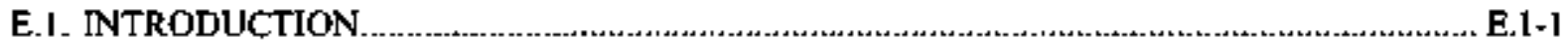

E.1.I RISK EVALUATION METHODOLOGY................................................................ E.\}-1

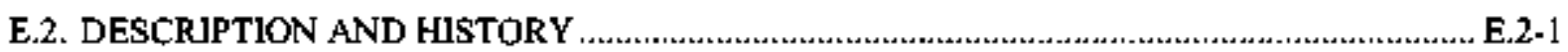

E.3. AVALLABLE DATA ..................................................................................................... E.3-1

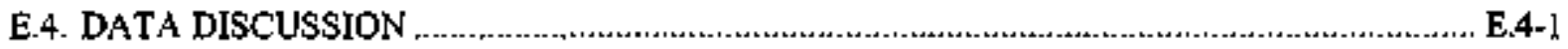

E.4.1 K-1251 BARGE FACILITY SOIL DATA …..................................................................... E.4-1

E.5. EXPOSURE ASSESSMENT ................................................................................

E.5.I EXPOSURE SCENARIO EVALUATION

E.5.1.I Industrial Scenario .............................................................................................. E.5-1

E.5.2 EXPOSURE PATHWAY IDENTIFICATION ……................................................. E.5-1

E.5.3 QUANTIFICATION OF EXPOSURE .....................................................

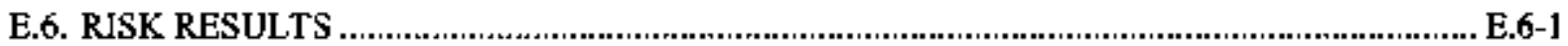

E.6.1 INDUSTRIAL SCENARIO ................................................................................ E.6-1

E.7. EVALUATION OF UNCERTAINTIES ….......................................................................... E.6-8

E.7.1 UNCERTAINTY IN THE SOURCE TERM ……................................................ . 7-1

E.7.2 UNCERTAINTY IN THE EXPOSURE ASSESSMENT …............................... E.7-2

E.7.3 UNCERTAINTY IN TOXICITY VALUES AND RISK PREDICTIONS ......................... E. 7-2

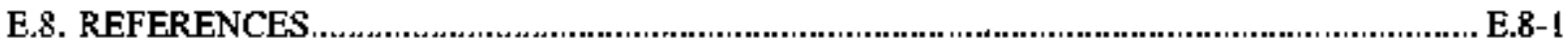

07-0985EM 102907 E-iii 


\section{FIGURES}

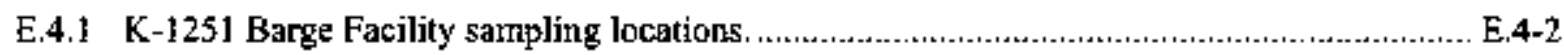

\section{TABLES}

E.6.1 Results of industrial risk screen for K-1251 Barge Facility soils....................................... E.6-2 


\section{ACRONYMS}

$\begin{array}{ll}\text { bgs } & \text { below ground surface } \\ \text { COPC } & \text { contaminant of potential concern } \\ \text { CPD } & \text { Clean Parcel Deternination } \\ \text { DOE } & \text { U. S. Department of Energy } \\ \text { EBS } & \text { Environmental Baseline Survey } \\ \text { EPA } & \text { U. S. Environmental Protection Agency } \\ \text { EPC } & \text { exposure point concentration } \\ \text { ETTP } & \text { East Tentesse Tochnology Park } \\ \text { HI } & \text { hazard index } \\ \text { HQ } & \text { hazard quotient } \\ \text { PRG } & \text { preliminary remediation goal } \\ \text { RAGS } & \text { Risk Assessment Guidonce for Superfund } \\ \text { RL } & \text { rentdial level } \\ \text { ROD } & \text { Record of Decision } \\ \text { TDEC } & \text { Tennessee Department of Environntent and Conservation }\end{array}$




\section{EXECUTIVE SUMMARY}

The goal of this risk evaluation is to determine the potential for adverse health effects associated with the K-1251 Barge Facility. The U. S. Department of Energy (DOE) is proposing to lease this facility to the Conmunity Reuse Organization of East Tennessee. Because the intended use of this area is as an industrial site, the risk evaluation seeks to determine if the land parcel is suitable for lease as an industrial facility.

The methodology followed in performing this risk evaluation included sereening the site data against nationally available preliminary remediation goals (PRGs) to provide screening-level risk estimates and detennine the need for a full risk calculation. The full risk calculation is conducted only when the screening-level risk estimates of constiments exceeding PRGs indicate the potential for elevated risks [cumulative screening-level risks exceeding E-04 or a hazard index (HI) above 1], or where no nationally recognized PRGs are available for the exposure scenario being considered. Additionally, although $\mathrm{K}-\mathrm{I} 25 \mathrm{I}$ is not within Zone 1 or Zone 2, sampling results were also compared with remediation levels (RLs) developed for the East Tennessee Technology Park (ETTP) Record of Decision (ROD) for either Zone lor Zone 2 soils, for informational puposes.

The U. S. Environmental Protection Agency has established a generally acceptable target risk range of E-04 10 E-06 (also expressed as $10^{-1}$ to $10^{-6}$ ) and a genterally acceptable $\mathrm{HI}$ of $\mathrm{t}$. The risk estimate is a value that represents the excess cancer incidence that might be expected due to the exposure scenario evaluated. The $\mathrm{HI}$ is a value that represents the potential for toxic effects to an exposed individual.

The screening-level risk estimate for the K-125I Barge Facility indicated the curnulative risks were below $1 E-04$ and the HI associated with site-related constituents did not exceed 1 ; therefore, a full risk calculation was not necessary. As stated above, because the risks did not exceed the generally acceptable upper risk level of E-04 or exceed an $\mathrm{HI}$ of 1, the risk evaluation was considered indicative of the low likelihood of adverse health effects associated with industrial exposure to the K-125l Barge Facility soils. The facility, therefore, is considered suitable for lease. 


\section{E.1. INTRODUCTION}

The goal of this risk evaluation is to determine the potential for adverse health effects associated wilh K.1251 Barge Facility, which is proposed for lease by the U. S. Department of Energy (DOE). Specifically, the objectives of this evaluation are: ( 1 ) to determine exposure to constituents based on available data for site media, and (2) to use these data to provide an estimate of the potential for adverse effects to human health. The risk calculations utilized in this evaluation are based on the document Risk Assessment Guidance for Superfund (RAGS) [EPA 1989]. The following sections describe the process used to provide a quantitative analysis of the risks to human bealth from exposure to the $\mathrm{K}-125 \mathrm{I}$ Barge Facility.

\section{E.1.1 RISK EVALUATION METHODOLOGY}

The risk evaluation methodology utilizes a step-wise process in order to more efficiently determine if the property under consideration is suitable (from a bealth perspective) for lease. As detailed below, the site data are screened against trigger levels first to determine if further examination of the data is necessary. By virtue of the decision needed to be made when examining the data (i.e., health protection), the screening process is conservative.

The risk evaluation method to support the lease of the K-1251 Barge Facility includes analysis of soil exposures. A process agreed to by both DOE and the regulators [i.e., U. S. Environmental Protection Agency (EPA) and Teruressee Department of Environment and Conservation (TDEC)] is utilized in order to be consistent with oher programs (e.g., Environmental Management). Soil sampling results are compared with Preliminary Remediation Goals (PRGs) or site-specific remediation levels (RLs). PRGs are health-protective concentrations that have been developed by EPA Region 9 as a set of national standards. RLs are bealth-protective concentrations that have been established in the site Records of Decision (RODs).

PRGs are developed based on a specific exposure scenario (i.e. industrial) and exposure pathways (soil ingestion, inhalation, and/or dermal contact) for a given level of risk and hazard [i.e., risk of 1E-05 and bazard quotient (HQ) of 1]. The risk represents the estimated number of increased oancer incidences for the exposed population (i.e., risk of JE-05 means a 1-in-100,000 increased incidence). The HQ is a measure of the potential for toxic effects from an individual contaminart, and the surn of HQs for multiple constituents is referred to as the hazard index (HI). An HI that exceeds 1 indicates the possibility that toxic effects may occur in the exposed population. The RLs use site-specific data to develop health-protective concentrations for contaminants that are site-related and considered widespread. Because site-specific data are used to develop RLs, they are higher in concentration than the PRGs.

As indicated above, the evaluation of risk and hazards is based on comparing soil sample results with PRGs and/or RLs. If there are constituents with concentrations in excess of the PRGs or RLs, further evaluation is conducted. To ensure that cumulative risks are below $1 \mathrm{E}-04$ and the overall HI is below 1 for the facility, as a back-check, the media concentrations are divided by the PRG to calculate a risk and H] eslimate. If the estimale indicates the potential for elevated risks andor hazards, a full risk calculation is conducted. The full risk calculation is based on an exposure assessment and identified exposure parameters (e.g., soil ingestion rate, exposure frequency, body weight, etc.) for the anticipated receptors. The results of the full risk calculation are then compared to the acceptable risk and hazard levels to deternine the potential for adverse health effects associated with soils in order to detemine if the property is suitable for lease. 
The following sections describe the process used to provide a quantitative analysis of the risks to human health while occupying the K-1251 Barge Facility. 


\section{E.2. DESCRIPTION AND HISTORY}

A full description and history of K-125] Barge Facility, as well as site maps, are presented in Chaps. 1 through 4 of the draft Baseline Environmental Analysis Report (BEAR) for the K-1251 Barge Facility study area (DOE 2007, in progress). 


\section{E.3. AVAILABLE DATA}

The data available for the K-125I Barge Facility study area consist of results from four soil sampling locations and two concrete sampling locations. Chapter 6 of the EBS provides a detailed evaluation of all available data, which are summarized in the following section. 


\section{E.4. DATA DISCUSSION}

The available data for the K-125I Barge Facility are discussed in detail in Chap. 6 of the EBS and are summarized below. Duplicate analyses were conducted at some locations for quality assurance. For the rists assessment, duplicate analyses were reduced to a single result (for each location, sample depth, and sampling date) in order to avoid biasing the datiset toward locations with duplicate analyses available. Where the original sample and duplicate were both detections, the larger detection was selected as the representative result. Where both the original and duplicate were non-detections, the sample with the lower detection limit was selected as the representative result. Non-detected results in the dataset were evaluated at half the detection linit when calculating mean and exposure point concentrations (EPCs) for the risk evaluation.

\section{E.4.1 K-1251 BARGE FACILITY SOIL DATA}

Soil data were collected in August 2007 and generated soit analytical results from three locations. Samples were collected from five sample intervals from 0 to $10 \mathrm{ft}$ below ground surface (bgs) and analyzed for metals, organics, and radionuclides. Additionally, data collected in 1994 from one historical sample location (RAD436) were included in the evaluation.

\section{E.4.2 K-125I HARGE FACLITY CONCRETE DATA}

Two samples of the concrete pad were collected in August 2007 at the X-1251 Barge Facility. These samples, collected from the top 3 in. of the concrete surface, were analyzed for PCBs and indicated that A.roclot-1254 and Aroclor-1260 were detected at concentrations rangfog from 0.002 to $0.0067 \mathrm{mg} / \mathrm{kg}$. These concentrations are well below the established $\mathrm{RL}$ of $10 \mathrm{mg} / \mathrm{kg}$ for PCBs in Zone 1 of the ETTP and the industrial worker PRG. As previously mentioned, PCBs were commonly used for their heat-resistant properties in oils, paints, and other materials. The industrial nature of the activities conducted at the barge facility likely accounts for the presence of PCBs on the concrete pad. 


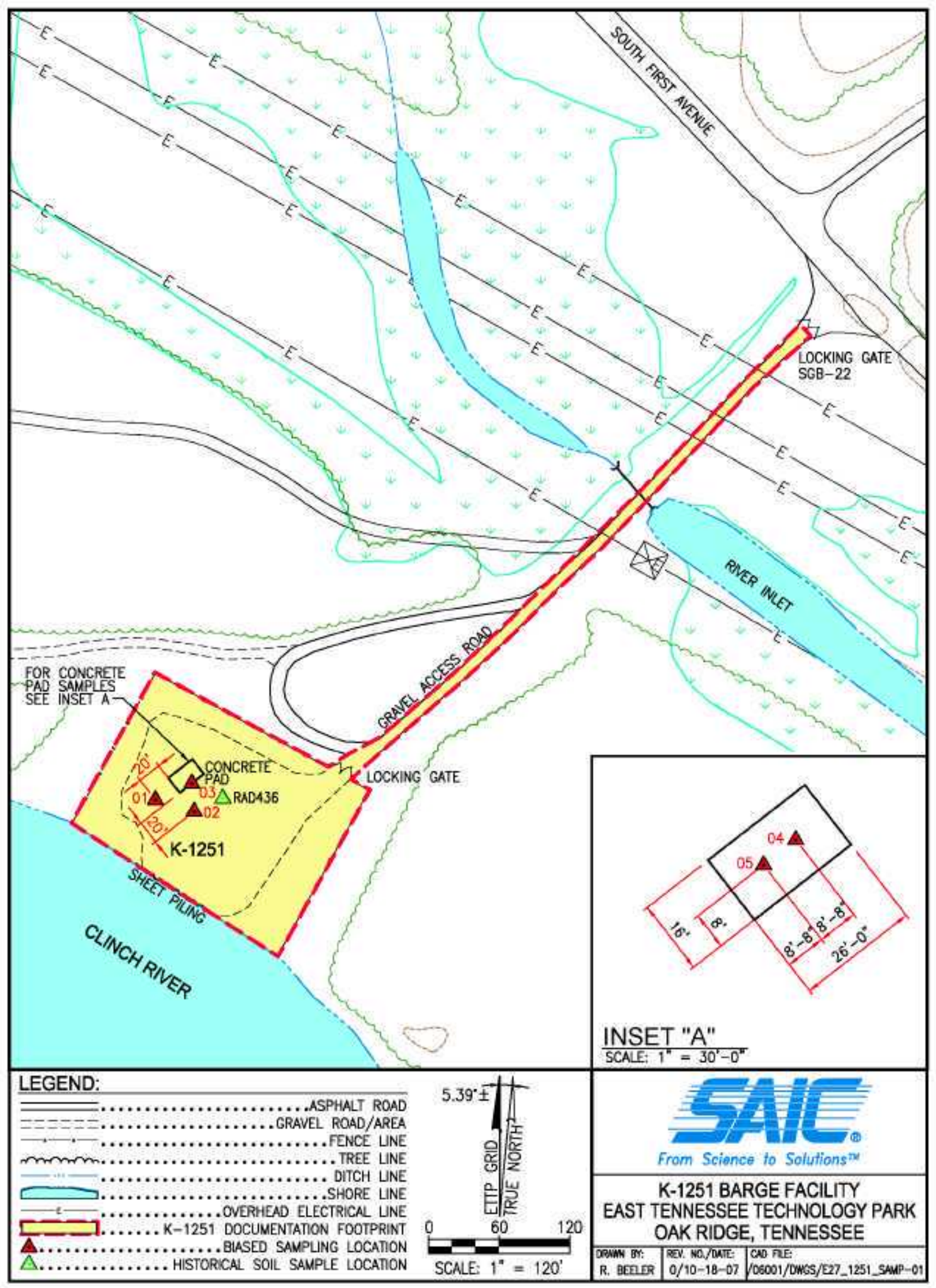

Fig. E.4.1. K-1251 Barge Facility soil sampling locations.

E. 4-2 


\section{E.5. EXPOSURE ASSESSMENT}

An exposure assessment combines information about sie characteristics and site-related data with exposure assumptions in order to quantify the intake of contaminants by a hypothetically exposed individual. The estimated exposure is based on the following:

- characterizing the exposure scenario based on site surveys,

- identifying complete exposure pathways based on assumed receptor activilies and site-specific information, and

- quantifying receptor exposure based on exposure assumptions and chemical-specific data

The steps in the exposure assessment are discussed in detail in the following sections.

\section{E.5.1 EXPOSURE SCENARIO EVALUATION}

Exposure scenarios are selected based on site surveys and anticipated uses of the K-1251 Barge Facility. The East Tennessee Technology Park (ETTP) area is being leased and transferred for industrial uses ranging from light to heavy industrial applications. Therefore, an industrial worker scenario was considered representative of current and future land use.

Exposures to the industrial worker, while spending time outside and within the lease area, were evaluated using soil sampling results. Exposure to concrete was not considered a likely exposure pathway since access to contaminants in the concrete matrix would require significant disturbance of the concrete pad, not included in the expected industrial activities. Uncertajnties associated with the exposure scenario evaluation are presented in Chap. E.7.

\section{E.5.1.1 Industrial Scenario}

The hypothetical industrial scenario assumes that an industrial worker may be present on the K-12\$1 Barge Facility currently and in the future. It is assumed that the industrial worker is exposed to soils from 0 to $10 \mathrm{ft}$ bgs, while working in the area. Details associated with this theoretical industrial scenario are presented in the following section.

\section{E.5.2 EXPOSURE PATHWAY IDENTIFICATION}

Evaluating the exposure pathways requires describing the mechanism by which an individual may become exposed to contaminants associated with K-1251 Barge Facility lease area soils. A complete exposure pathway requires the following:

- a source of contamination,

- a pathway of migration frem the source of contamination to the exposure point,

- a receptor present at the exposure point, and

- an exposure mechanism at the exposure point.

If any one component of a complete exposure pathway is missing, then the pathway is considered incomplete. Only complete exposure pathways were evaluated in the risk screen. 
Complete exposure pathways associated with K-1251 Barge Facility soils include ingestion, inhalation, dermal contact. and external exposure to ionizing radiation. The ingestion pathway is complete because contaminated media may be present, a receptor may be present on the parcel, and a receptor may contact and ingest contaminants from the media. The inhalation patbway is complete because contaminated media may be present, contaminants may become aitbome, a receptor may be present on the parcel, and an individual thay inhale contaminants in the air. The dermal pathway is complete because contaninated media may be present, a receptor may be present on the parcel, and a receptor may contact and demally absotb contaminants from the media. Extemal exposure to ionizing radiation is a complete exposure pathway because radionuclides may be present in media, ionizing radjation may be emitted, and a receptor may be present to absotb the radiation. The following section describes how each of these exposure pathways was quantified in the risk screen.

\section{E.5.3 QUANTIFICATION OF EXPOSURE}

Quantifying the exposure to the receptor requires the following:

- statistical evaluation of the representative dataset;

- selection of contaminants of potential concern (COPCs), based on comparison to PRGs;

- identification of the COPCs that bave available toxicity data and can be quantinatively evaluated;

- estimation of the exposure parameters appropriate to the exposure scenarios;

- selection of toxicity data appropriate for the receptor and exposure pathways; and

- calculation of the intake, risks, and bazards to the receptors based on the calculated exposure concentrations (Chap, E.6).

The ingestion, inhalation, dermal contact, and external exposure pathways were quantified using available data. The purpose of the quantification of exposures is to provide a conservative estimate of exposures related to the exposure seenarios evaluated. At each slep in the quantification process, assumptions are made in order to provide an upper-bound estimate of risk that is protective of human health.

The evaluation of the K-1251 Barge Facility was based on the following industrial worker exposure scenario:

- the industrial worker is exposed to K-1251 Barge Facility soils for 2 hours each week;

- the industrial worker ingests $100 \mathrm{mg} / \mathrm{d}$ of contaminated soil; and

- the industrial worker inhales $20 \mathrm{~m}^{3} / \mathrm{d}$.

As described in the risk evaluation methodology in Sect. E.1.1, for the K-1251 Barge Facility study urta soils, delected concentrations were compared with EPA Region 9 industrial PRGs al a risk level of $1 E-05$ and an $\mathrm{HQ}$ of $\mathrm{I}$, as well as site-specific RLs. Results of the risk evaluation are presented in Chap. E.6. 


\section{E.6. RISK RESULTS}

The risk estimate is a value that represents the excess cancer incidence that might be expected due to the exposure scenario evaluated. The EPA has established a generally acceptable target risk range of $\mathrm{E}-04$ to $\mathrm{E}-0.06$ (also expressed as $10^{-4}$ to $10^{-6}$ ) and a target Hil of 1 . The following sections present the risk results for the K-125] Barge Facility study area.

\section{E.6.I INDUSTRIAL SCENARIO}

Hypothetical industrial exposures associatcd with K-1251 Barge Facility soils may occur via ingestion, inhalation, demal contact, and external exposure. As discussed in the previous section, EPA Region 9 industrial PRGs and ETTP RLs were used to screen the soils as follows:

- each detected result was compared with EPA Region 9 PRGs for the industrial scenario at risk level $1 E-05$ and an $\mathrm{HQ}$ of 1 ;

- detected results were compared with the RLs developed for the ETTP ROD; and

- detected results were compared with background levels provided by Bechtel Jacobs Company LLC.

Table E.6.1 presents the results of the K-1251 Barge Facility risk evaluation based on industrial exposures. None of the chemical constituents exceed their respective PRGs. Of the site-related radiological constituents, only ${ }^{137} \mathrm{Cs}$ exceeded the PRGs calculated at the $1 \mathrm{E}-05$ ELCR level (Note that ${ }^{226} \mathrm{Ra}$, ${ }^{228} \mathrm{Th}$, and ${ }^{232} \mathrm{Th}$ have background levels that exceed their respective PRGs, and ${ }^{228} \mathrm{Ra}$ is considered to be in equilibrium with ${ }^{232} \mathrm{Th}$. These constituents are considered site-wide COPCs and ase extmpted from consideration for individual facilities per DOE2002a). The data also indicate that no detected concentrations exceeded maximum RLs, and all average detected concentrations were below average RLs.

As discussed in Sect. E.J.2, as a back-check, the results of the serten were tvaluated to determine if the generally acceptable upper risk level of $E-04$ (also expressed as $10^{-4}$ ) and $\mathrm{HI}$ of 1 were exceeded as follows:

- constituents with detected concentrations above the PRGs were evaluated to detemine if the average detected concentration would result in a tisk exceeding E-04 or an HI exceeding $\mathrm{l}$. These screning-level risk estimates are based on dividing average detected concentrations for each constituent by their respective PRGs where appropriate, and

- in the case of multiple constituents with detected concentrations above PROs, an evaluation was conducted to determine if the screening-level risk estimates based on average detected concentrations might exceed a risk of E-04 or an $\mathrm{Hl}$ of 1 .

The screening-level risk estimate indicated the cumulative risks from K-1251 Barge Facility soils were below $\mathrm{JE}-04$ and the HI was below 1. Because the risks did not exceed the generally acceptable upper risk level of $\mathrm{E}-04$ or $\mathrm{HI}$ of $\mathrm{I}$, no further evaluation was needed, and a full risk calculation was not conducted. The screening was considered indicative of the low likelihood of adverse health effects associated with industrial exposure to K-1251 Barge Facility soils. K-1251 Barge Facility is, therefore, considered suitable for lease. 


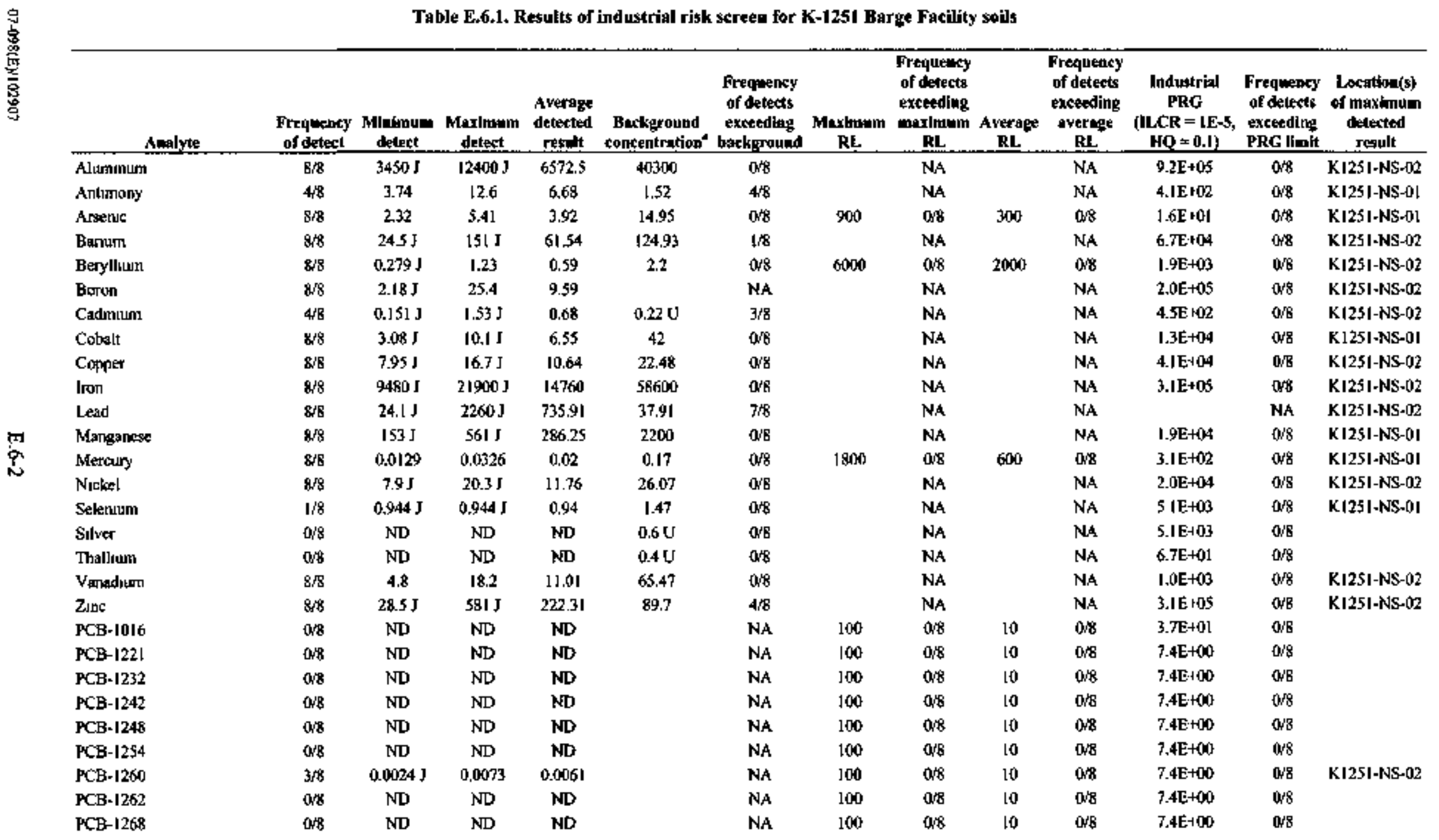


Table E.6.1. Results of industrial risk screen for K-1251 Barge Facility soiks (contipued)

\begin{tabular}{|c|c|c|c|c|c|c|c|c|c|c|c|c|c|}
\hline Analyte & $\begin{array}{c}\text { Frtipuency } \\
\text { of detect }\end{array}$ & $\begin{array}{c}\text { Minlmum } \\
\text { defect }\end{array}$ & $\begin{array}{c}\text { Maximam } \\
\text { detect }\end{array}$ & $\begin{array}{c}\text { Averate } \\
\text { detected } \\
\text { rebuh }\end{array}$ & $\begin{array}{l}\text { Beckgromend } \\
\text { coneentratlon }\end{array}$ & $\begin{array}{c}\text { Frequency } \\
\text { of detects } \\
\text { exceeding } \\
\text { bsckeround }\end{array}$ & $\begin{array}{c}\text { Masimum } \\
\text { RL }\end{array}$ & $\begin{array}{c}\text { Frequetcy } \\
\text { of detects } \\
\text { exeeteding } \\
\text { nesimnin } \\
\text { RL } \\
\end{array}$ & $\begin{array}{c} \\
\text { Average } \\
\text { RL }\end{array}$ & $\begin{array}{l}\text { Frequency } \\
\text { of detects } \\
\text { exceedint } \\
\text { avergge } \\
\text { RL }\end{array}$ & $\begin{array}{c}\text { Indestrial } \\
\text { PRG } \\
\text { (LCR = 1E-5, } \\
\text { HQ }=0.1)\end{array}$ & $\begin{array}{l}\text { Frequessy } \\
\text { of detects } \\
\text { crtcedling } \\
\text { PRC limí } \\
\end{array}$ & $\begin{array}{l}\text { Location(e) } \\
\text { of maxilnum } \\
\text { detected } \\
\text { resull }\end{array}$ \\
\hline Amenc|ाफाr-24| & $0 / 8$ & ND & ND & ND & & NA & & NA & & NA & $5.7 E+0$ 이 & 088 & \\
\hline Btsmuth-2I2 & 7 & 0,283 & 0.592 & 0.48 & & NA & & NA & & $\mathrm{NA}$ & $3.75+05$ & 07 & KI25I-NS-01 \\
\hline Cesiurtr137 & $7 B$ & 0.016 & 3.14 & 1.16 & I & $3 / 8$ & 20 & $0 / 8$ & 2 & $1 / 8$ & J.IE+W0 & $2 / 8$ & $\mathrm{~K} 1251-\mathrm{N} 5-02$ \\
\hline Coball-60 & $1 / 8$ & 0.0159 & 0.0159 & 0.02 & & NA & & NA & & NA & 6.0E-0l & 088 & $\mathrm{~K}|25|-N 5-02$ \\
\hline Leachli2 & $8 / 8$ & 0.385 & 1.21 & 0.72 & & NA & & $\mathrm{NA}$ & & NA & $6.1 E+04$ & 0.88 & K12S1-NS-02 \\
\hline Leact-214 & $8 / 8$ & 0.335 & 1.59 & 0.74 & & NA & & NA & & $\mathrm{NA}$ & $7.5 E+05$ & 068 & $\mathrm{~K} 1251-\mathrm{NS}-02$ \\
\hline Neplunsum-237 & 08 & ND & ND & ND & & NA & 50 & 008 & 5 & ONR & $2.7 \mathrm{E}+00$ & $0 / 8$ & \\
\hline Plulonum-238 & $0 / 8$ & ND & ND & ND & & NA & & $\mathrm{NA}$ & & $\mathrm{NA}$ & $1.7 \mathrm{E} \mid \mathbf{0 2}$ & $0 / 8$ & \\
\hline Plulordum-239 & $1 / 8$ & $0.17 \mathrm{~J}$ & $0.17 \mathrm{~J}$ & 0.17 & & NA & & NA & & $\mathrm{NA}$ & $1.5 \mathrm{E}+02$ & $0 / 8$ & $\mathrm{~K} 1251 \cdot \mathrm{NS} \cdot 02$ \\
\hline Radimm-226 & 88 & 0.362 & 1.46 & 0.65 & 1.25 & $1 / 8$ & 15 & ars & 5 & of 8 & $2.6 \mathrm{E}-0 \mid$ & $B / 8$ & $\mathrm{~K} 1251-\mathrm{NS}-102$ \\
\hline Radium-228 & 818 & 0.406 & 1.28 & 0.73 & & NA & & NA & & NA & $1.6 \mathrm{E}-02$ & $8+8 * 6$ & $\mathrm{~K} .1251-\mathrm{NS}-02$ \\
\hline Strontbutn-90 & $0 / 8$ & ND & ND & ND & & $\mathrm{NA}$ & & NA & & NA & ]. $1 E+02$ & $0 / 8$ & \\
\hline Technetsurn-99 & $0 / 8$ & ND & ND & ND & & NA & & NA & & NA & $8.9 \mathrm{E}-03$ & $0 / 8$ & \\
\hline Thallium-208 & $8 / 8$ & 0.116 & 0.382 & 022 & & NA & & NA & & NA & $3.7 \mathrm{E}+0 \mathrm{~S}$ & $0 / 8$ & Kl251-NS-02 \\
\hline Thonแm-228 & $8 / 8$ & $0.43 \mathrm{~J}$ & $1.37 \mathrm{~J}$ & 0.78 & 1.86 & $0 / 8$ & & NA & & $\mathrm{N}_{\mathrm{A}}$ & $1.6 \mathrm{E}-02$ & $848 * 6$ & $\mathrm{~K} 1251-\mathrm{NS}-12$ \\
\hline Thomum-230 & $8 \sqrt{8}$ & $0.496 \mathrm{~J}$ & $2.14 \mathrm{~J}$ & 0.97 & 1.2 & $1 / 8$ & & NA & & NA & $2.1 \mathrm{E}+02$ & $0 / 8$ & K1251-NS-02 \\
\hline Tlonum-232 & $8 / 8$ & 0.381 & $1,5 J$ & $0.7 B$ & 1.95 & ors & 15 & a/s & $s$ & ors & 1. $6 \mathrm{E}-02$ & $8 / 8^{* * * 3}$ & KI251-NS-02 \\
\hline Thonum-234 & 88 & 0.18 & 1.48 & 0.94 & & NA & & NA & & $\mathrm{N}_{\mathrm{A}}$ & $3.3 \mathrm{E}+04$ & os & $K 1251-N S-02$ \\
\hline Uгатиแтा-234 & $8 / 8$ & $0.431 \mathrm{~J}$ & $1.7 \mathrm{~J}$ & 0.97 & 1.47 & $2 \sqrt{8}$ & 7000 & $0 / 8$ & 700 & ors & $3.3 E+02$ & ors & K.1251-NS-02 \\
\hline Urantum-235 & $3 / 8$ & $0.0885 \mathrm{~J}$ & $0.265 \mathrm{~J}$ & 0.15 & & NA & 80 & $0 / 8$ & 8 & $\mathbf{b} / \mathbf{B}$ & $3.9 \mathrm{E}+00$ & ons & $\mathrm{K}: 251-N S-12$ \\
\hline Uramum-238 & $8 / 8$ & $0,565 \mathrm{~J}$ & $1.56 \mathrm{~J}$ & 0.91 & 1.47 & $1 / 8$ & solo & $0 / 8$ & 50 & $a r B$ & $1.8 \mathrm{E} \cdot 10 \mathrm{I}$ & $0 / 8$ & K1251-NS-02 \\
\hline 1,1-buphesulyl & a/s & ND & ND & ND & & NA & & NA & & NA & $2.3 E+104$ & $0 / 8$ & \\
\hline $1,2,4,5-T$ etruchloraberatze & org & ND & ND & ND & & $N_{A}$ & & NA & & NA & I. $8 \mathrm{E}+02$ & $0 / 8$ & \\
\hline 1,2,4-Trichlorabenzene & ats & ND & ND & ND & & NA & & NA & & NA & $2.2 \mathrm{E} 102$ & $0 / 8$ & \\
\hline 1.2-Dichlonbenzene & $0 / 8$ & ND & ND & ND & & NA & & NA & & $\mathrm{NA}_{\mathrm{A}}$ & $4.1 E+103$ & $0 / 8$ & \\
\hline 1,3-Drchlorobenzemse & $0 / 8$ & ND & ND & ND & & $\mathrm{NA}_{\mathrm{A}}$ & & NA & & NA & $2.1 \mathrm{E}+03$ & of 8 & \\
\hline 1,4-Drdldombenzene & 88 & $0.04026 \mathrm{~J}$ & $0.000859 \mathrm{~J}$ & $0.0005 ?$ & & NA & & NA & & NA & $7,9 \mathrm{E}+0 \mathrm{l}$ & $0 / 8$ & $\mathrm{~K} 1251-\mathrm{NS}-02$ \\
\hline 2,3,4,6-T trischloripheriol & ars & ND & ND & ND & & $N_{A}$ & & NA & & NA & $1.8 E+04$ & $0 / 8$ & \\
\hline 2,4,5-Tnchlorophenol & $0 / 8$ & ND & ND & ND & & NA & & $\mathrm{NA}$ & & NA & $6.2 \mathrm{E}-04$ & $0 / 8$ & \\
\hline 2,4,6-Techlorophenol & 08 & ND & ND & ND & & NA & & $N A$ & & NA & $6.2 \mathrm{E} \div 0 \mathrm{I}$ & $0 / 8$ & \\
\hline
\end{tabular}


Toble E.6.1. Reaulds of tudostrial risk screen fur K-1251 Barge Facilily soik (continued)

\begin{tabular}{|c|c|c|c|c|c|c|c|c|c|c|c|c|c|}
\hline Analyte & $\begin{array}{c}\text { Frequency } \\
\text { of detect }\end{array}$ & $\begin{array}{c}\text { Minlonom } \\
\text { detext }\end{array}$ & $\begin{array}{c}\text { Maximum } \\
\text { detect }\end{array}$ & $\begin{array}{c}\text { Avernge } \\
\text { detected } \\
\text { respult }\end{array}$ & $\begin{array}{l}\text { Bockground } \\
\text { censentration }\end{array}$ & $\begin{array}{l}\text { Frequency } \\
\text { of deftects } \\
\text { exceeding } \\
\text { buctseround }\end{array}$ & $\begin{array}{c}\text { Maximum } \\
\text { RL }\end{array}$ & $\begin{array}{c}\text { Frequency } \\
\text { of detects } \\
\text { exceeting } \\
\text { maximum } \\
\text { RL } \\
\end{array}$ & $\begin{array}{c}\text { Averase } \\
\text { RL }\end{array}$ & $\begin{array}{c}\text { Freyorncy } \\
\text { of detects } \\
\text { exceeding } \\
\text { average } \\
\text { RL } \\
\end{array}$ & $\begin{array}{c}\text { Industrial } \\
\text { PRG } \\
\text { (ILCR }=1 \mathrm{E}-5, \\
\text { HQ }=0.1 \text { ) }\end{array}$ & $\begin{array}{l}\text { Frequency } \\
\text { of detects } \\
\text { exceedlug } \\
\text { PRG Hind }\end{array}$ & $\begin{array}{c}\text { Locartion(s) } \\
\text { of maximam } \\
\text { detested } \\
\text { resulf }\end{array}$ \\
\hline 2,4-Drchlorophenol & ors & ND & ND & ND & & $\mathrm{NA}$ & & $\mathrm{NA}$ & & NA & ].8E +03 & ors & \\
\hline 2,4-Dirnethylphenol & $0 / 8$ & ND & ND & ND & & NA & & $\mathrm{NA}$ & & NA & $1.2 \mathrm{E}+04$ & ors & \\
\hline 2,4-Dinutrophenre] & 08 & ND & ND & ND & & NA & & NA & & NA & $1.2 \mathrm{E}+\mathbf{0} 3$ & o/s & \\
\hline 2,4-Duturtubluluene & $0 / 8$ & ND & ND & ND & & NA & & $\mathrm{NA}$ & & NA & 2.SE+0I & $0 / 8$ & \\
\hline 2,6-Dintrololuente & $0 / 8$ & ND & ND & ND & & $N_{A}$ & & $\mathrm{NA}$ & & $\mathrm{NA}$ & $2.5 \mathrm{E}+01$ & $0 / 8$ & \\
\hline 2-Clalorchaphthatene & $\mathrm{N} B$ & ND & ND & ND & & NA & & $\mathrm{NA}$ & & $\mathrm{NA}$ & $2.3 \mathrm{E}+04$ & ord & \\
\hline 2-Chloriphenoi & 048 & ND & ND & ND & & $N_{A}$ & & $\mathrm{NA}_{\mathrm{A}}$ & & $\mathrm{NA}$ & $2.4 \mathrm{E}-102$ & ars & \\
\hline 2-Methyl-4,6-dımLtrophenol & ors & ND & ND & ND & & NA & & $\mathrm{NA}$ & & NA & $6.2 \mathrm{E}+0 \mathrm{I}$ & ors & \\
\hline 2-Methylphenol & $0 / B$ & ND & ND & ND & & $\mathrm{NA}$ & & $\mathrm{NA}$ & & NA & $3.1 \mathrm{E}+04$ & $0 / 8$ & \\
\hline 2-Nutratenzenamume & $0 / 8$ & ND & ND & ND & & $\mathrm{NA}$ & & $\mathrm{NA}$ & & $\mathrm{NA}$ & $1.8 \mathrm{E}+03$ & or 8 & \\
\hline 3,3'-Drchlorabenarduse & $0 / 8$ & ND & ND & ND & & $N_{A}$ & & NA & & NA & $3,8 \mathrm{E}+01$ & $0 / 8$ & \\
\hline 3.N11robenzenaminge & 018 & ND & ND & ND & & NA & & NA & & $\mathrm{NA}$ & 1. $.8 E+02$ & $a / 8$ & \\
\hline 4-Chlorobenzestamine & ar & ND & ND & ND & & NA & & $\mathrm{NA}$ & & NA & $2.5 \mathrm{E}+03$ & $0 / 8$ & \\
\hline 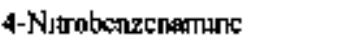 & 08 & ND & ND & ND & & $\mathrm{NA}$ & & $\mathrm{NA}$ & & NA & $8.2 \mathrm{E}+02$ & $0 / 8$ & \\
\hline Acenaphthene & $2 / 8$ & $0.0113 \mathrm{~J}$ & $0.0242 \mathrm{~J}$ & 0.02 & & NA & & $\mathrm{NA}$ & & NA & $2.9 E+04$ & ars & $\mathrm{K} 1251 \cdot \mathrm{N} 5 \cdot 03$ \\
\hline Anthracence & $3 / 8$ & $0.0187 \mathrm{~J}$ & $0.0655 \mathrm{~J}$ & 0.04 & & $N_{A}$ & & NA & & NA & $2.4 \mathrm{E}+05$ & ors & K1251-NS-03 \\
\hline Benzz(a)anthracenc & $3 / 8$ & $0.0592 \mathrm{~J}$ & $0.129 \mathrm{~J}$ & 0.19 & & NA & & $\mathrm{NA}$ & & $\mathrm{NA}$ & $2.1 \mathrm{E}+01$ & $0 / 8$ & K1251-NS-103 \\
\hline Befzizaldelyyde & $0 / 8$ & ND & ND & ND & & NA & & $\mathrm{NA}$ & & NA & $6.2 E+04$ & ors & \\
\hline Benzo(a)pyrene & $4 / 8$ & $0.0663 \mathrm{~J}$ & $0.139 \mathrm{~J}$ & 0.1 & & NA & & $\mathrm{NA}$ & & $\mathrm{NA}$ & $2.1 E+00$ & $0 / 8$ & K1251-NS-03 \\
\hline Benzog(b) flutranthente & $3 / 8$ & $0.0705 \mathrm{~J}$ & $0.213 \mathrm{~J}$ & 0.12 & & $\mathrm{NA}$ & & NA & & NA & $2.1 \mathrm{E} \perp \mathbf{0 I}$ & Ors & $\mathrm{K}[25]-\mathrm{NS}-02$ \\
\hline Beszo $(k)$ fluoranthene & $1 / 8$ & $0.0268 \mathrm{~J}$ & $0.0268 \mathrm{~J}$ & 0.03 & & NA & & NA & & $\mathrm{NA}$ & $2.1 \mathrm{E}+02$ & $0 / 8$ & K1251-NS-01 \\
\hline Biss(2-chlopethyl) ether & ord & ND & ND & ND & & $\mathrm{NA}$ & & NA & & NA & $5.8 \mathrm{E}-100$ & ors & \\
\hline Bes(2-ctlorolsopropyl) ether & $0 / 8$ & ND & ND & ND & & NA & & NA & & $\mathrm{NA}$ & $7,4 E+01$ & $0 / 8$ & \\
\hline B1s(2-ethylhexyl)phthalale & or & ND & ND & ND & & NA & & $\mathrm{NA}$ & & NA & $1.2 \mathrm{E}+03$ & ord & \\
\hline Butyl berizyl phathalate & of & ND & ND & ND & & NA & & NA & & NA & $12 \mathrm{E}+05$ & $0 / 8$ & \\
\hline Caprolactam & 018 & ND & ND & ND & & NA & & $\mathrm{NA}$ & & $\mathrm{NA}$ & $3.1 \mathrm{E}+0 \mathrm{~S}$ & $0 / 8$ & \\
\hline Carbazole & $1 / 2$ & $0.0553 \mathrm{~J}$ & $0.0553 \mathrm{~J}$ & 0.06 & & $\mathrm{NA}$ & & $\mathrm{NA}$ & & $\mathrm{NA}$ & $8.6 \mathrm{E}+02$ & $0 / 8$ & $\mathrm{~K} 1251-\mathrm{NS}-03$ \\
\hline Chrysere & $3 / 8$ & $0.0524 \mathrm{~J}$ & $0.119 \mathrm{~J}$ & 0.1 & & $\mathrm{NA}$ & & $\mathrm{NA}$ & & $\mathrm{NA}$ & $2.1 E+03$ & $0 \cos$ & $\mathrm{K} / 251 \cdot \mathrm{NS}-03$ \\
\hline Di-tr-budy] phatalale & 018 & ND & ND & ND & & NA & & NA & & $\mathrm{NA}$ & $6.2 \mathrm{E}+04$ & $0 / 8$ & \\
\hline DH-actylphthalate & 048 & ND & ND & ND & & NA & & NA & & NA & $2.5 \mathrm{E}+0.4$ & $2 / 8$ & \\
\hline
\end{tabular}


Tabje E.6.1. Results of Industrjal rlsk sereen for K-I251 Barge Facility solls (continued)

\begin{tabular}{|c|c|c|c|c|c|c|c|c|c|c|c|c|c|}
\hline Amalyte & $\begin{array}{c}\text { Frequency } \\
\text { of detect }\end{array}$ & $\begin{array}{c}\text { Min'mul } \\
\text { detept }\end{array}$ & $\begin{array}{c}\text { Moximum } \\
\text { detext }\end{array}$ & $\begin{array}{l}\text { Average } \\
\text { detected } \\
\text { resalt }\end{array}$ & $\begin{array}{l}\text { Background } \\
\text { concentration }\end{array}$ & $\begin{array}{l}\text { Frequency } \\
\text { af detects } \\
\text { exceeding } \\
\text { backgrournd }\end{array}$ & $\begin{array}{c}\text { Maxlmam } \\
\quad \mathrm{RL} \\
\end{array}$ & $\begin{array}{l}\text { Frequency } \\
\text { af deterts } \\
\text { exceeding } \\
\text { onnimam } \\
\text { Ra. }\end{array}$ & $\begin{array}{c}\text { Average } \\
\text { RL } \\
\end{array}$ & $\begin{array}{c}\text { Frequency } \\
\text { of deterts } \\
\text { erceeding } \\
\text { avermge } \\
\text { RL } \\
\end{array}$ & $\begin{array}{c}\text { Industrial } \\
\text { PRG } \\
\text { (ILCR }=1 \mathrm{E}-5,5 \\
\text { HQ }=0.1) \\
\end{array}$ & $\begin{array}{l}\text { Frequency } \\
\text { al detects } \\
\text { exceedting } \\
\text { PRC linit }\end{array}$ & $\begin{array}{c}\text { Location(s) } \\
\text { of maximum } \\
\text { defected } \\
\text { result }\end{array}$ \\
\hline Dibenz $(a, h)$ anthracene & $0 / 8$ & ND & ND & ND & & NA & & $N_{A}$ & & $\mathrm{NA}$ & $2.1 \mathrm{E}+00$ & $0 / 8$ & \\
\hline Dibenzoturan & o. 8 & ND & ND & ND & & $\mathrm{NA}$ & & $\mathrm{NA}$ & & $\mathrm{NA}$ & |.6E+03 & 088 & \\
\hline Dhethyl phuthalate & $0 / 8$ & ND & ND & ND & & NA & & $N_{A}$ & & $\mathrm{Na}$ & $4.9 E+05$ & $0+s$ & \\
\hline Dutmettyl phuthalale & ors & ND & ND & ND & & NA & & NA & & NA & $6.2 \mathrm{E}+06$ & $0 \%$ & \\
\hline Drphenylamine & $0+8$ & ND & ND & ND & & NA & & $\mathrm{NA}$ & & $N_{A}$ & $1.5 \mathrm{E}+04$ & $0 / \mathrm{h}$ & \\
\hline Fluspranthene & $7 / 8$ & $0.014 \mathrm{~J}$ & $0283 \mathrm{~J}$ & 0,08 & & NA & & $\mathrm{NA}$ & & $\mathrm{NA}$ & $2.2 E+04$ & 암요 & KI25I-NS -03 \\
\hline Fluorene & $2 / 8$ & $0.0133 \mathrm{~J}$ & $0.0301 \mathrm{~J}$ & 0.02 & & $\mathrm{NA}_{\mathrm{A}}$ & & NA & & NA & $2.6 \mathrm{E}+04$ & $0 / 8$ & KI23I-NS-03 \\
\hline Hexachlorobenzence & 0.8 & ND & ND & ND & & NA & & $\mathrm{NA}$ & & NA & I.JE-101 & 018 & \\
\hline Hexachlorobutadrene & ord & ND & ND & ND & & NA & & $\mathrm{NA}$ & & NA & $1.8 \mathrm{E}+02$ & $0+8$ & \\
\hline Hexachlonocyclopentadlene & ars & ND & ND & ND & & NA & & $\mathrm{NA}$ & & NA & $3, \pi \mathrm{E}+03$ & 08 & \\
\hline Hexachlotoelthane & $0 / 8$ & ND & ND & ND & & NA & & NA & & NA & $6.2 \mathrm{E}+02$ & ars & \\
\hline Indenic( $(1,2,3 \cdot c d)$ pyiste & $5+8$ & $0.128 \mathrm{~d}$ & $0.163 \mathrm{~J}$ & 0.14 & & NA & & $\mathrm{NA}$ & & $\mathrm{NA}$ & 2.1 $\mathrm{E}+0 \mathrm{l}$ & $0 / 8$ & K.125.I-NS-02 \\
\hline Isophorone & $0 / 8$ & ND & ND & ND & & NA & & NA & & $\mathrm{NA}$ & $5.1 \mathrm{E}+03$ & as & \\
\hline N-Nitroso-di-n-propylarniste & ors & ND & ND & ND & & NA & & NA & & $N_{A}$ & $2.5 \mathrm{E}-100$ & $O H$ & \\
\hline Naphthalente & $1 / 8$ & $0.0135 \mathrm{~J}$ & $0.0135 \mathrm{~J}$ & 0.01 & & NA & & NA & & NA & $1.9 \mathrm{E}-02$ & $0 / 8$ & KI2SI-NS-03 \\
\hline Nitroberzenc & 0/8 & ND & ND & ND & & NA & & NA & & $\mathrm{NA}$ & $1.0 \mathrm{E}+02$ & ors & \\
\hline Pentachilotophenol & 0,8 & ND & ND & ND & & $\mathrm{NA}$ & & NA & & NA & $9.0 \mathrm{E}+0 \mid$ & $0 / 8$ & \\
\hline Phenol & $0+8$ & ND & ND & ND & & NA & & NA & & $\mathrm{NA}$ & {$[.8 \mathrm{E} \div 05$} & $O B$ & \\
\hline Pyrene & $6+8$ & $0.0215 \mathrm{~J}$ & $0.221 \mathrm{~J}$ & 0.09 & & $\mathrm{NA}$ & & NA & & NA & $2.9 \mathrm{E}+04$ & 98 & KI25I-NS-03 \\
\hline I,I,1-Tnchloryethalle & 08 & ND & ND & ND & & $\mathrm{NA}$ & & NA & & NA & $6.9 \mathrm{E}+03$ & $9 / 8$ & \\
\hline $\begin{array}{l}\text { 1,1,2,2-Tetrachlorocthane } \\
\text { 1,1,2-Tnehloro-1,2,2-- }\end{array}$ & $0+8$ & ND & ND & ND & & $N_{A}$ & & $\mathrm{NA}_{\mathrm{A}}$ & & NA & $9.3 E+000$ & 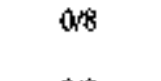 & \\
\hline influopothane & aAs & ND & ND & ND & & NA & & NA & & $\mathrm{NA}$ & $6.9 \mathrm{E}+0.4$ & 018 & \\
\hline 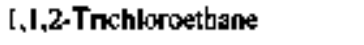 & or & ND & ND & ND & & NA & & NA & & NA & $1.6 \mathrm{E}+0 \mathrm{l}$ & OHB & \\
\hline 1,I-Dichloroethane & $0+8$ & ND & ND & ND & & $\mathrm{NA}$ & & $\mathrm{NA}$ & & NA & $1.7 \mathrm{E}+03$ & $0 / 8$ & \\
\hline $\begin{array}{l}\text { 1, I-Dichloroethene } \\
\text { 1,2-Dibromo-3. }\end{array}$ & $3 / 8$ & $0.000595 \mathrm{~J}$ & 0.000955 & 0.00072 & & $\mathrm{NA}$ & & $\mathrm{NA}$ & & $\mathrm{NA}$ & 4. $1 \mathrm{E}+02$ & $\alpha B$ & KI251-NS-0I \\
\hline chkoropropkene & $0 / 8$ & ND & ND & ND & & NA & & NA & & NA & $\{. \mid E+0\}$ & ars & \\
\hline 1,2-Dibromoethane & $0 / 8$ & ND & ND & ND & & NA & & $N_{A}$ & & $\mathrm{NA}$ & $6.3 \mathrm{E}-9 \mathrm{i}$ & 088 & \\
\hline 1, 2-Dichloroethaste & 0,8 & ND & ND & ND & & NA & & NA & & $\mathrm{NA}$ & $6.0 \mathrm{E}+00$ & $0 / 8$ & \\
\hline 1,2-Duchloropripane & a/8 & ND & ND & ND & & $\mathrm{NA}$ & & $\mathrm{NA}$ & & $\mathrm{NA}_{\mathrm{A}}$ & $7.4 \mathrm{E}+00$ & $0+8$ & \\
\hline
\end{tabular}




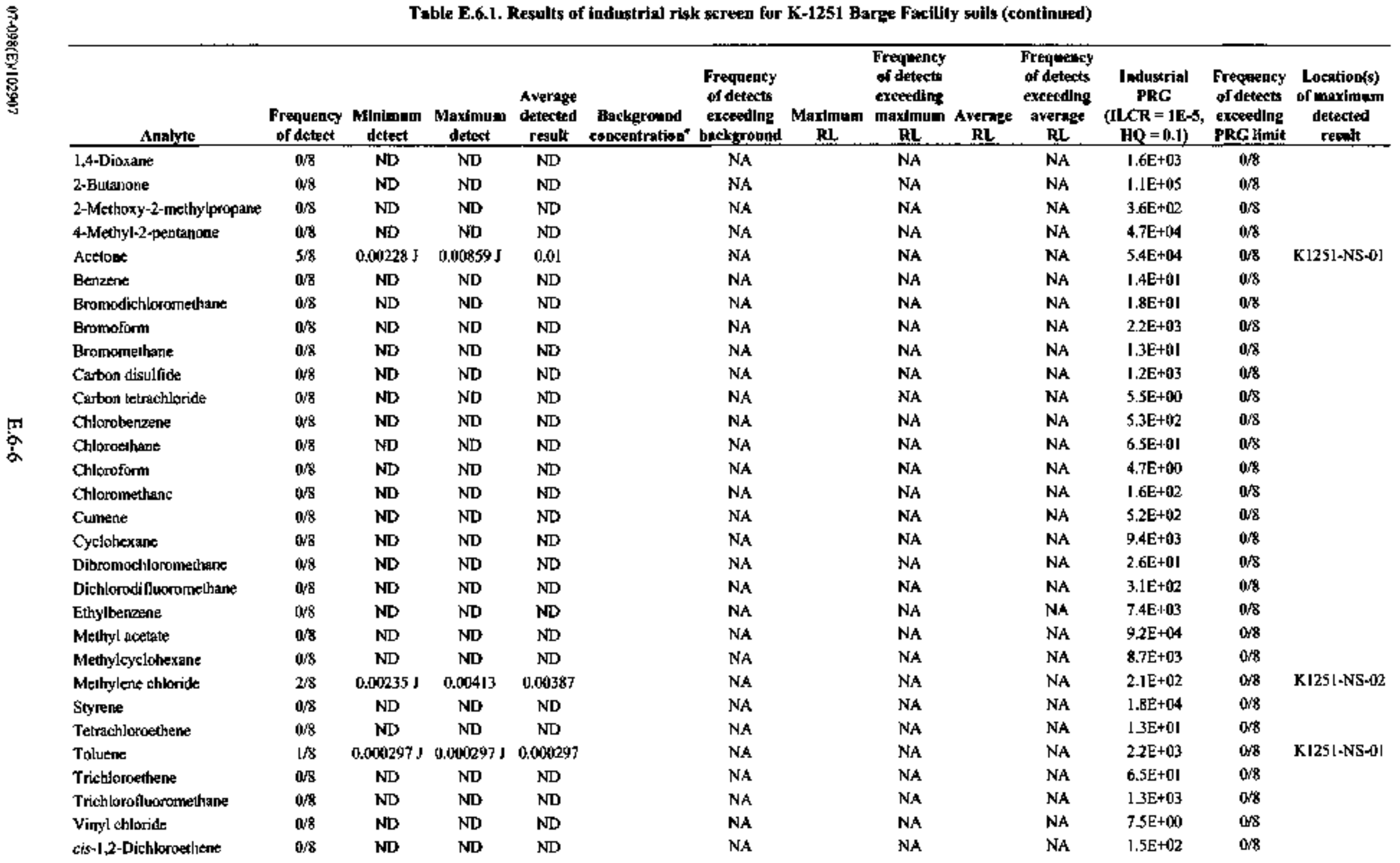


Table E.6.1. Results of industrial risk struen for K-1251 Barge Facllity soils (contiaued)

\begin{tabular}{|c|c|c|c|c|c|c|c|c|c|c|c|c|c|}
\hline Anslyte & $\begin{array}{l}\text { Prequincy } \\
\text { of deteet }\end{array}$ & $\begin{array}{c}\text { Minimum } \\
\text { detect }\end{array}$ & $\begin{array}{c}\text { Maximanum } \\
\text { detext }\end{array}$ & $\begin{array}{c}\text { Averige } \\
\text { detected } \\
\text { resulk }\end{array}$ & $\begin{array}{l}\text { Backgromod } \\
\text { conerntration }\end{array}$ & $\begin{array}{c}\text { Frequency } \\
\text { of detects } \\
\text { exceeding } \\
\text { backtspund }\end{array}$ & $\begin{array}{c}\text { Maximü } \\
\text { RL }\end{array}$ & $\begin{array}{c}\text { Frequency } \\
\text { of detects } \\
\text { exceeding } \\
\text { maximusi } \\
\text { RL } \\
\end{array}$ & $\begin{array}{c}\text { Atwertage } \\
\text { R: }\end{array}$ & $\begin{array}{c}\text { Frequency } \\
\text { of detects } \\
\text { exceedint } \\
\text { averagt } \\
\text { RL }\end{array}$ & $\begin{array}{c}\text { Industrial } \\
\text { PRG } \\
\text { (ILCR - 1E-5, } \\
\text { HQ }=0.1 \text { ) }\end{array}$ & $\begin{array}{l}\text { Frequewcy } \\
\text { of defects } \\
\text { treceding } \\
\text { PRG Imil } \\
\end{array}$ & $\begin{array}{l}\text { Lactilion(s) } \\
\text { of maximum } \\
\text { detected } \\
\text { restill } \\
\end{array}$ \\
\hline trans-1,2-Dichlorosthenc & $0 / 8$ & $\mathrm{ND}$ & ND & ND & & NA & & $\mathbf{N A}$ & & NA & 235102 & $0+8$ & \\
\hline
\end{tabular}

Units are in picocures per gram (pCNg) or sulligrams per kılogramt $(\mathrm{mg} / \mathrm{kg}$ )

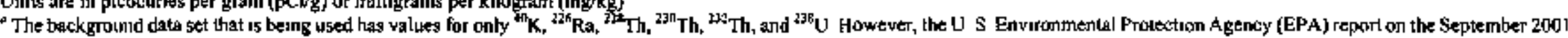

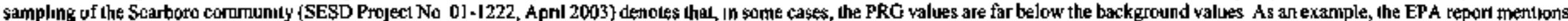

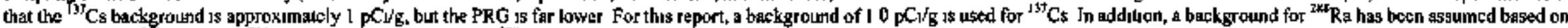

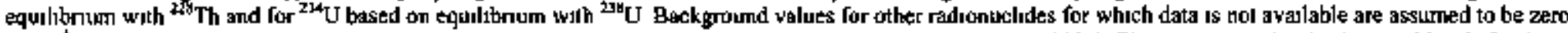

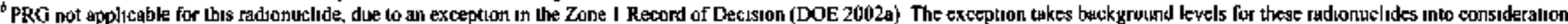

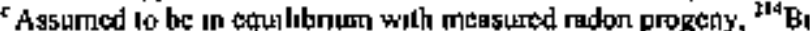

$\checkmark$ Assumed to be in equilibrium with measured progeny. ${ }^{28} \mathrm{Ac}$

NA = Nol applieable, not avalable, or unsufficient dala lo calculale the statistic

$\mathrm{ND}=$ - Nod detecterd

PCB $=$ polychlotmated baphenyl

RL = remediation level 


\section{E.7. EVALUATION OF UNCERTAINTIES}

The estimation of uncertainly, whether quantitative or qualitative, is fundamental to scientific activities that involve measured or assessed quantities. Estimates of risk are conditional based on a number of assumptions conceming exposure. Generation of a point estimate of tisk, as tas been done in this screening-level assessnent, has the potential to yield under- or overestimates of the actual value and can lead to improper decisions. Therefore, it is necessary to specify the assumptions and uncertainties inherent in the screening-level evaluation process to place the risk estimates in perspective and ensure that anyone making risk-management decisions is well informed.

Uncertainty about environinental risk estimates is known to be at least an order of magninude or greater (EPA 1989). The evaluation of uncertinties for the assessment is qualitative, since the resource requirements necessary to provide a quantitative statistical uncertainty analysis for this study area would generally outweigh the benefits. The focus of the discussion in this section will be on the important variables and assumptions that contribute most to the overall uncertainty.

\section{E.7.1 UNCERTAINTY IN THE SOURCE TERM}

Several uncertainties are associated with the data set and the data evaluation process. These uncertainties include the selection of COPCs and the determination of the EPC.

Although the data evaluation process used to select COPCs adheres to established procedures and guidance, it also requires making decisions and developing assumptions on the basis of historical information, process knowledge, and best professional judgment about the data. Uncertainties are associated with all such assumptions. The background concentrations and PROs used to sereen analytes are also subject to uncertainty. The toxicity values used in the derivation of PRGs are subject to change; as additional information (from scientific research) becomes available, these periodic changes in toxicity values may cause the PRG values to change as wetl, causing increased uncertainty in the data screening process.

Representative concentrations and olber statistics are calculated in this risk screen based on the assumption that the samples collected are truly random samples. Some of the data may not have been taken randondy, but rather may bave come from biased sampling, ained at identifying high contaminant concentration locations.

This evaluation has been performed using only the COPCs with available toxicity data. It should be noted that the qualitative COPCs detenuined for this study area could potentially increase the risks/hazards to a receptor. Radionuclides that are short-lived isotopes were eliminaled from the dataset, along with daughter products of isotopes that inejude the contribution of the daughter in the PRG calculation to overestimating their contribution to the overall risks.

Additional uncertainty is associated with the inclusion of constituents, which are present at concentrations similar to concentrations found in background samples. The effect of including these constituents in the risk evaluation is to overestimate the site-related risks and toxic effects associated with the K-125] Barge Facility (see Chap. E.6). 


\section{E.7.2 UNCERTAINTY IN THE EXPOSURE ASSESSMENT}

For cach exposure pathway, assumptions are made concerning the parameters, the routes of exposure, the amount of contarninated media an individual can be exposed to, and intake rates for different routes of exposure. In the absence of site-specific data, the assumptions used in this assessment are consistent with EPA-approved paramelers and default values. When several of these upper-bound values are combined in estimating exposure for any one pathway, the resulting risks can be in excess of the $99 \mathrm{lh}$ percentile and, therefore, outside the range that may be reasonably expected.

The guidance values for intake rates and exposure parameters are assumed to be representative of the bypothetical populations evaluated. Afl contaminant exposures and intakes are assumed to be from the site-related exposure media (i.e., no other sources contribute to the receptor's risk). Even if these assumptions are true, other areas of uncertainty may apply. Selected intake rates and population characteristics (i.e., weight, life span, and activities) are assumed to be representative of the exposed population. The consistent conservatism used in the estimation of these parameters generally leads to overestimation of the potential risk to the postulated receptors.

\section{E.73 UNCERTAINTY IN TOXICITY VALUES AND RISK PREDICTIONS}

Uncertainty in the values used to represent the dose-response rejationship will highily impact the risk estimates. These uncertainties are contaminant-specific and are embedded in the toxicity value. The factors that are incorporated to represent sources of uncertainty include the source of the data, duration of the study, extrapolations from short- 10 long-term exposures, intrahuman or interspecies variability, and other special considerations. In addition, toxicity varies with the chemical form.

Uncertainties related to the summation of carcinogenic risk and non-carcinogenic bazard estimates across contaminants and parhways ase a primary uncertainty in the risk characterization process. In the absence of information on the toxicity of specific chemical nixtures, additive (cumulative) risks are assumed (EPA 1989).

Limitations of the additive risk approach for exposure to multiple chemicals include the following:

1. The slope factors may represent the mean but often represent the upper 95 th percentile estimate of potency (the central estimate on the mean for radionuclides), so the summation can result in an excessively conservative estimate of lifetime risk.

2. The reference doses do not have equal accuracy or precision and are not based on the same severity of effects.

3. The effects of a mixture of carcinogens are unknown, and possible interactions could be synergistic or antagonistic.

Despite these limitations and the general unavailability of data on these interactions, summations were perfomed for the carcinogenic risks and chemical hazards presented in the risk screen. This approach is consistent with RAGS (EPA 1989).

In order to avoid double-counting the short-lived daughters of specific isotopes, the daughters were excluded from the COPC list if analytical results for the parent were available; only daughters as defined by EPA (2001) were excluded. As a special case, the ${ }^{232} \mathrm{Th}$ decay chain was evaluated as ${ }^{4233} \mathrm{~Tb}+\mathrm{D}$ " (which combines the slope factors for ${ }^{232} \mathrm{~Tb}_{2}{ }^{228} \mathrm{Ra}+\mathrm{D}$, and ${ }^{22 \mathrm{\theta}} \mathrm{Th}+\mathrm{D}$ ) when calculating risks. When evaluating data 


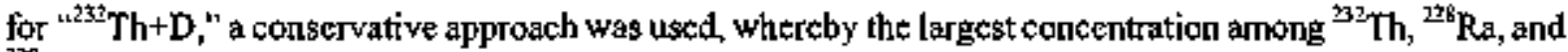
${ }^{228} \mathrm{Th}$ was used to deternine the maximum detected concentration and to estimate all summary statistics. Another special consideration for radioisotopes was to eliminete ${ }^{\text {th }} \mathrm{K}$ from the COPC list, as it was considered to be naturally occurring and, therefore, was not considered to be a COPC. 


\section{E.8. REFERENCES}

DOE (U. S. Department of Energy) 1999. Remedial Imvestigation Report for the East Tennessee Technology Park Oak Ridge, Tennessee, DOE/OR/01-1778N1\&D2, U. S. Department of Energy, Office of Environmental Management, Oak Ridge, TN, January.

DOE 2002a Record of Deciston for Interim Actions in Zone 1. East Tennessee Technology Park, Oak Ridge, Tennessee, DOE/OR/01-1997\&D2, U. S. Department of Energy, Office of Environmental Management, Oak Ridge, TN.

DOE 2002b. Oak Ridge Performance Management Plan, Rev. 6, U. S. Department of Energy, Office of Environmental Management, Oak Ridge, TN, August 28.

DOE 2007 (in progress). Draft Baseline Environmental Analysis Report Baseline Survey Report for the $X$-I25/ Barge Facility at the East Tennessee Technology Park, Oak Ridge, Tennessee, BJC/OR-2885, U. S. Department of Energy, Office of Nuclear Fuel Supply, Oak Ridge, TN.

EPA (U.S. Environmental Protection Agency) 1989. Risk Assessment Guidance for Superfund, Vol. I: Human Healh Evaltation Mamal (Part A), EPA/540/1-89/002, Washington, D.C.

EPA 1991. Risk Assessment Guidance for Superfund, Volume 1: Human Health Evaluation Manuat, Supplemental Guidance, Standard Default Exposure Factors, Interim Final, OSWER Directive 9285.6-03, Office of Emergency and Rernedial Response, Washington, D.C.

EPA 1992. Supplemental Guidance to RAGS: Colculating the Concentration Term, OSWER Directive 9285.7-081, Office of Solid Waste and Emergency Response, Washington, D.C.

EPA 1996. Soil Screening Guidance: Technical Background Document, Office of Solid Waste and Emergency Response, Washington D.C.

EPA 1997. Exposwe Factors Handbook, EPA/600/P-95/002Fa, Office of Research and Development, National Center for Environmental Assessment, Washington, D.C. (found on the World Wide Web at bttp://www.epa.gov/ncea/pdfs/eth/front.pdf).

EPA 2000. Supplementof Guidance to RAGS: Region IV Bulletins, Human Health Risk Assessment, Attanta, GA (available on the World Wide Web at http://www,epa gov/tegion4/waste/ots/healtbul.htm).

EPA 2001. Healuh Effects Assessment Summary Tables (HEAST), available on the World Wide Web at http: $/$ www.epa.gov/Jadiation/heast/index.html.

EPA 2002. Guidance for Comparing Background and Chemical Concentrations in Soil for CERCLA Sites, EPA 540-R-01-003, Oftice of Solid Waste and Emergency Response, Washington, D.C., found on the World Wide Web at hittp//wuw.epa.gov/superfund/programs/risk/bsckground.pdf.

EPA 2004a Region 9 Preliminary Remediation Goals (PRGs), DeL 2004 update, created by Stanford J. Smucker, found on the World Wide Web at http//unw.epa.gov/Regions/waste/sfund/prg/index.htm. 
EPA 2004b. Risk Assessment Guidance for Superfund Volume I: Human Heath Evaluation Mamual (Part E. Supplemental Guidance for Dermal Risk Assessment) Final, OSWER 9285.7-02EP, Office of Superfund Remediation and Technology Innovation. Washington, D.C., August, found on the World Wide Web at http://www.epa.gov/superfund/programs/risk/ragse/introduction.pdf. 
BJC/OR-2885

\section{RECORD COPY DISTRIBUTION}

File-EMEF DMC-RC 